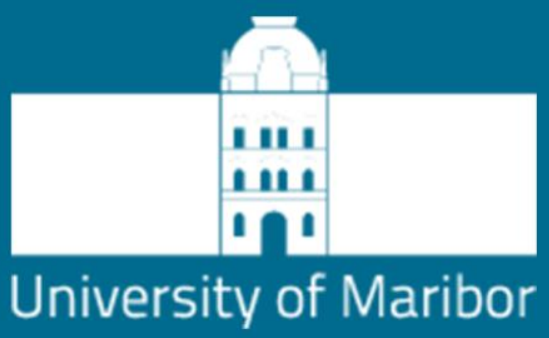

\title{
Legal Regulation of Possession in the Republic of Slovenia
}

Author:

dr. Renato Vrenčur 


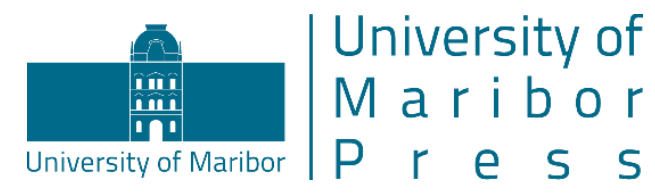




\section{(C) University of Maribor Press}

All rights reserved. No part of this book may be reprinted or reproduced or utilized in any form or by any electronic, mechanical, or other means, now known or hereafter invented, including photocopying and recording, or in any information storage or retriveal system, without permission in writing from the publisher.

Title: $\quad$ Legal Regulation of Possession in the Republic of Slovenia

Author: $\quad$ assoc. prof. dr. Renato Vrenčur (University of Maribor, Faculty of Law)

Review: $\quad$ prof. dr. Matjaž Tratnik (University of Maribor, Faculty of Law), prof. dr. Miha Juhart (University of Maribor, Faculty of Law)

Proofreading: Katja Drnovšek (University of Maribor, Faculty of Law)

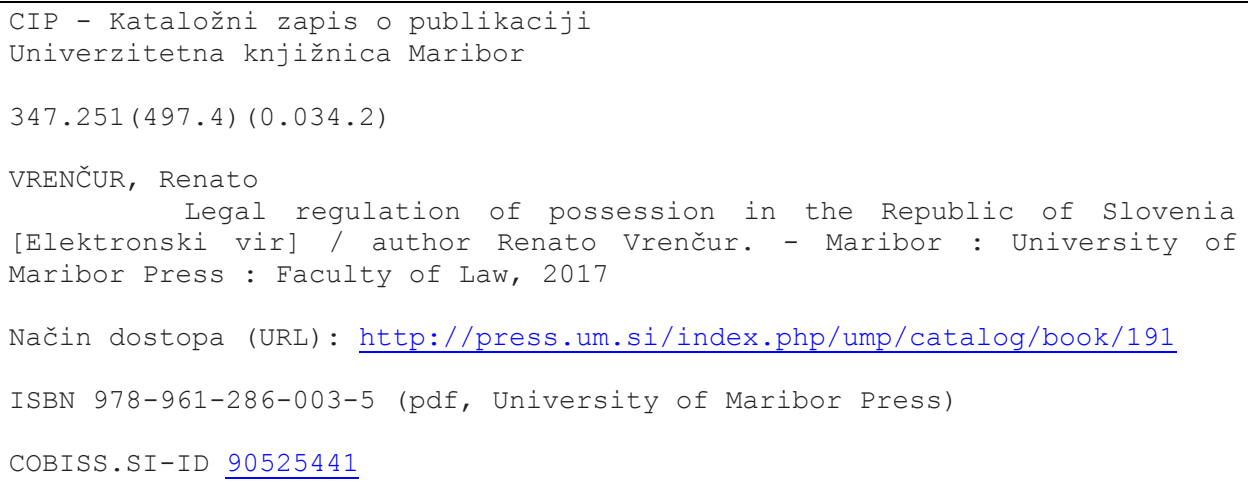

First published 2017 by

University of Maribor Press

Slomškov trg 15, 2000 Maribor, Slovenia

tel: +386 (0)2 25042 42, fax: +386 (0)2 2523245

http://press.um.si, zalozba@um.si

\section{Co-published by}

\section{University of Maribor, Faculty of Law}

Mladinska ulica 9, 2000 Maribor, Slovenia

tel. +386 (0)2 25042 00, fax: +386 (0)2 2523245

www.pf.um.si, info.pf@um.si

Price: free copy

\section{For Publisher:}

prof. dr. Igor Tičar (University of Maribor, Faculty of Law) 



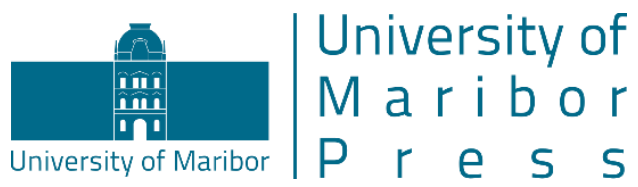

\section{Legal Regulation of Possession in the Republic of Slovenia}

Author:

Renato Vrenčur 



\title{
Legal Regulation of Possession in the Republic of Slovenia
}

\author{
RENATO VRENČUR
}

\begin{abstract}
Possession is actual control over a thing. While the relationship between a possessor and a thing allows the former to use the thing, enjoy it and dispose of it, it is not important if he or she also has the right to do so. Possession represents one of fundamental components (entitlements) of ownership, which, despite the fact that it only represents actual control over a thing, nevertheless indicates certain belonging of a thing to a person who exercises actual control. Possession is not a right and therefore does not include fundamental entitlements, but it does contain the entitlement to legal protection. A possessor, who does not necessarily even have the right to possess a thing, may require protection of possession either through selfhelp or with an action. The monograph comprehensively discusses regulation of possession, and at the same time offers systematically collected and arranged recent case law in this field.
\end{abstract}

Keywords: • property law $\bullet$ possession $\bullet$ real rights $\bullet$ legal protection $\bullet$ disturbance of possession

CorRespondence AdDRess: Renato Vrenčur, Ph.D., Associate Professor, University of Maribor, Faculty of Law, Mladinska ulica 9, 2000 Maribor, Slovenia, email: renato.vrencur@um.si.

DOI 10.18690/978-961-286-003-5

ISBN 978-961-286-003-5 



\section{Tabel of Contents}

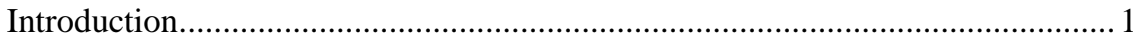

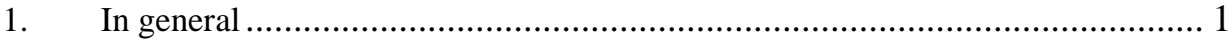

2 Objective conception of possession under SPZ ……............................... 3

3 Distinction between subjective and objective conceptions of possession ........... 4

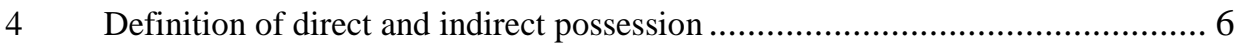

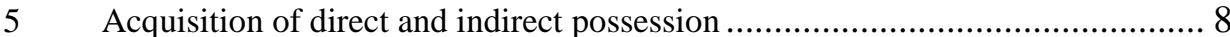

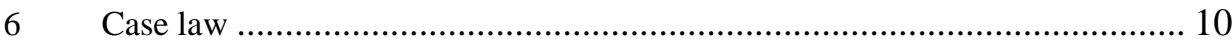

6.1 No possession of a right or negative real servitude ...................................... 10

6.2 The manner in which actual control over a thing is exercised........................ 11

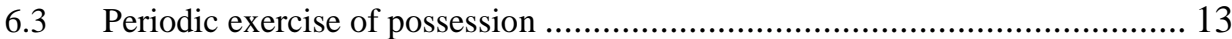

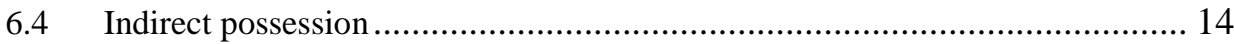

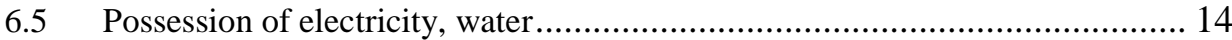

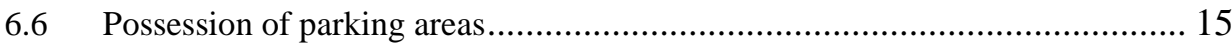

6.7 Transferring possession of immovable property........................................ 16

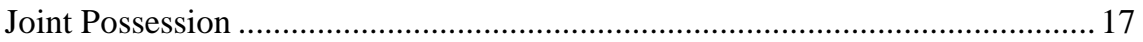

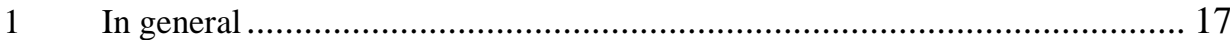

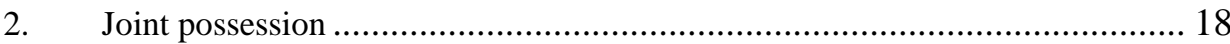

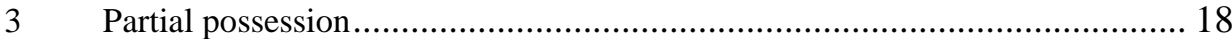

$4 \quad$ Multiparty states of possession that correspond to states of ownership............ 19

5 Legal effects of the agreement on the use of a thing (on the exercise of possession

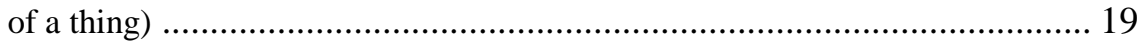

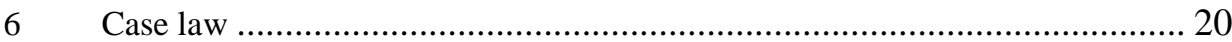

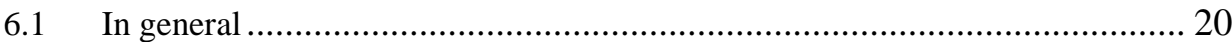

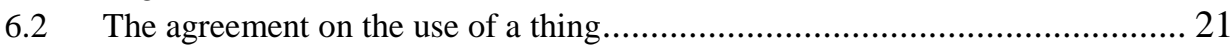

6.3 "Possession of servitude" is actually joint possession of a servient estate ........ 22

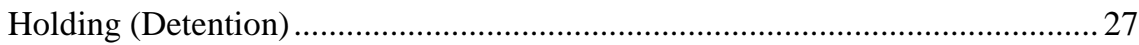

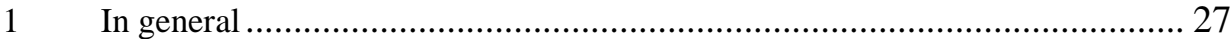

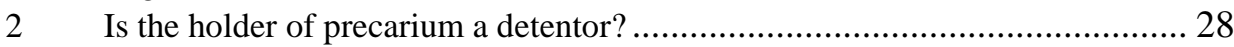

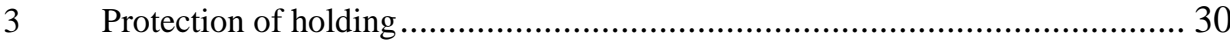

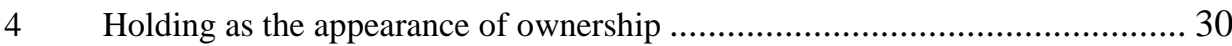

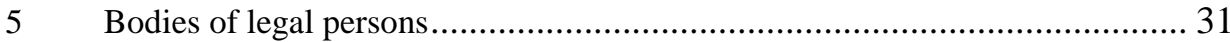

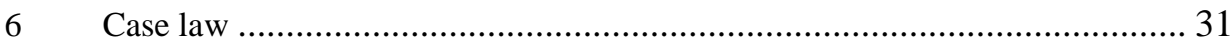

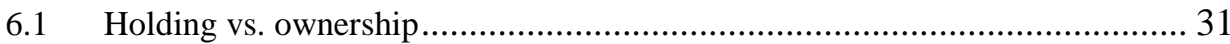




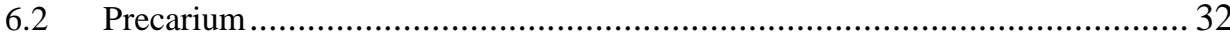

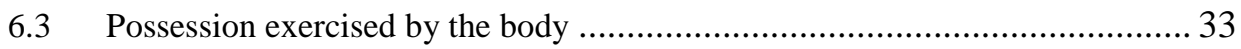

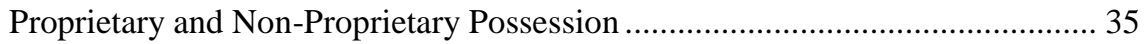

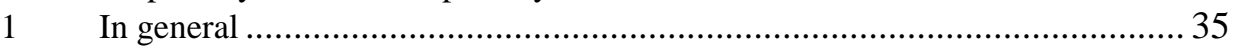

2 Proprietary and non-proprietary possession ……..................................... 35

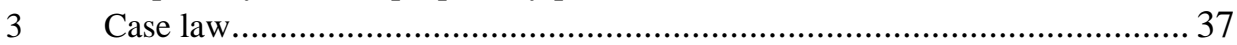

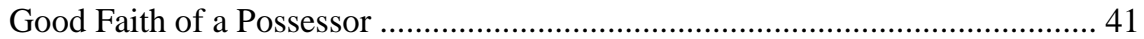

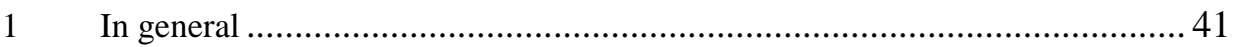

2 Special cases of acquisition.................................................................. 42

3 Good faith of a proprietary possessor of immovable property....................... 43

4 Good faith of a legal person, possessory successor and co-owner .................... 43

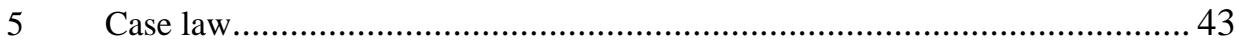

Acquisition of Possession by an Heir ................................................................ 45

1 In general 45

2 What form of possession is inherited by the heir? ....................................... 45

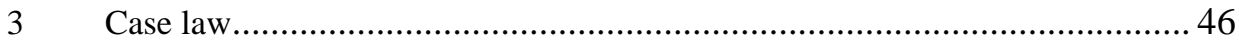

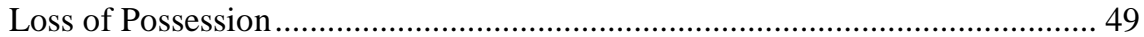

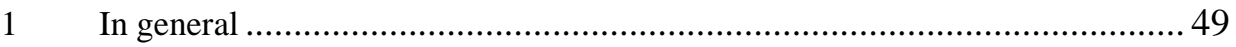

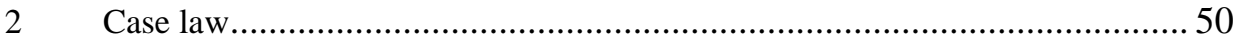

Self-Help as a Subsidiary Form of Possessory Protection.................................... 53

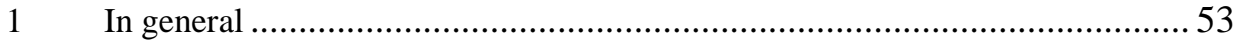

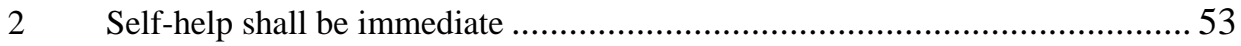

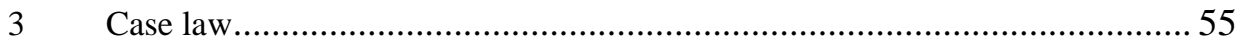

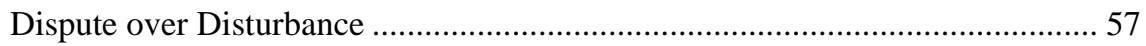

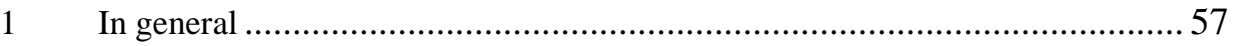

2 Legal nature of time limits for bringing an action for disturbance of

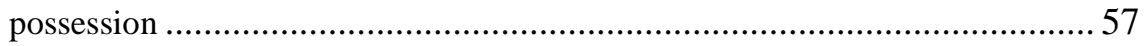

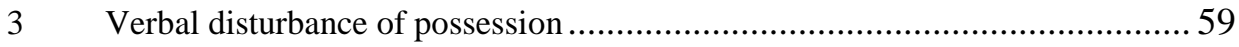

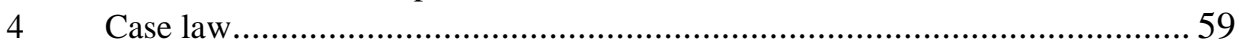

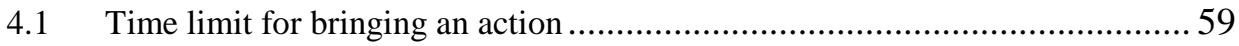

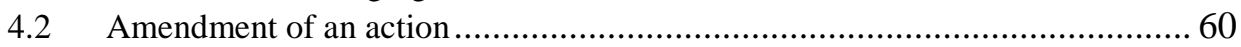

4.3 Recurring and continuous disturbing conduct ............................................ 61

Special Characteristics of Judicial Protection of Possession ................................. 63

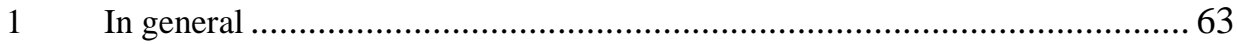




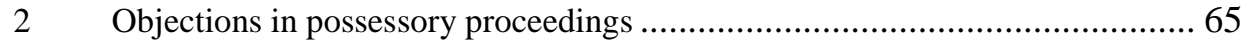

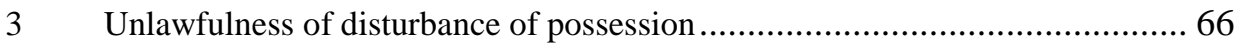

$4 \quad$ Protection of direct and indirect possession ............................................... 67

5 The intensity of disturbance of possession and economic interests of the

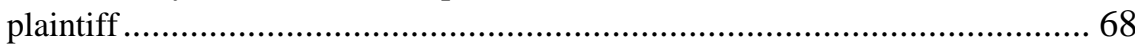

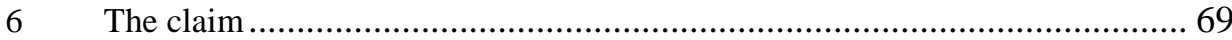

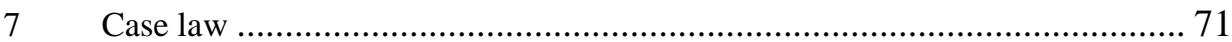

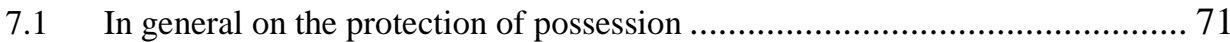

7.2 Intensity of disturbance of possession and economic interests of the plaintiff .. 75

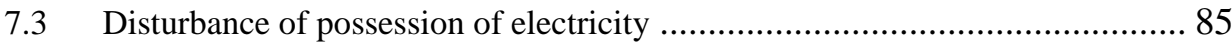

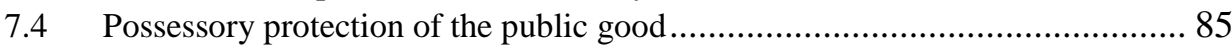

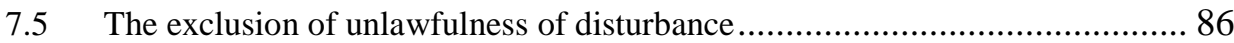

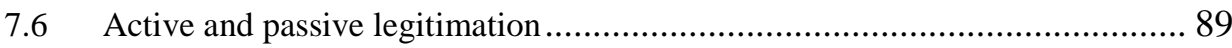

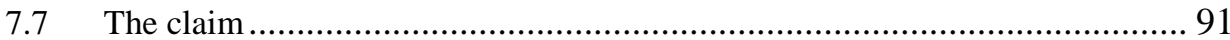

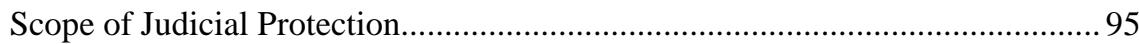

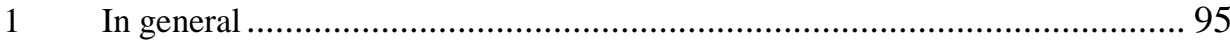

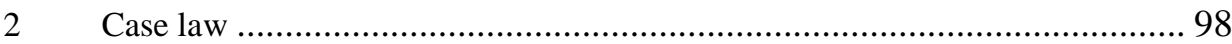

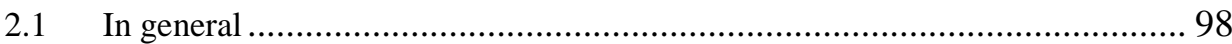

2.2 Operative part of the decision on disturbance of possession .......................... 98

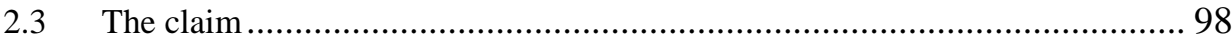

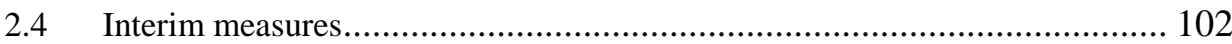

Protection in the Case of Two or More Possessors ............................................. 105

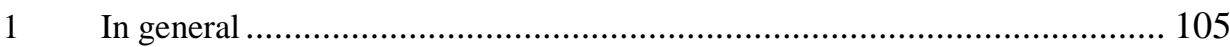

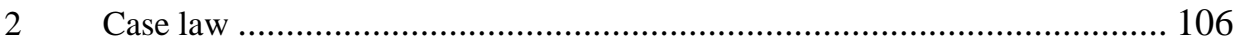

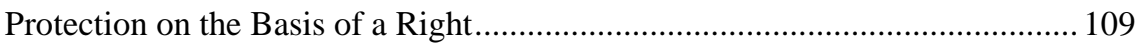

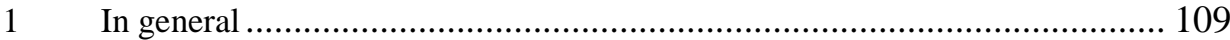

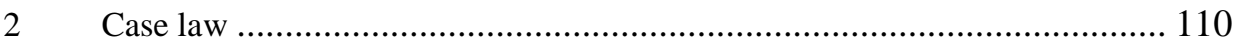




\section{Introduction}

\section{In general}

Discussions about possession usually begin as follows: "Possession is a complicated legal structure, which often even causes problems for lawyers." Although possession is not a right, it nevertheless gives a possessor the entitlement to legal protection. The entitlement to legal protection is encompassed by rights. Thus, for example, the ownership right consists of a set of entitlements (1. the entitlement to use a thing, which gives its holder a legal option to possess, use and enjoy the thing in the broadest possible manner; 2 . the entitlement to dispose of a thing, which gives its holder a legal option to alienate, encumber, and transform the ownership and 3. the entitlement to legal protection, which gives its holder a legal option to protect fundamental entitlements). Possession is not a right and therefore does not include fundamental entitlements, but it does contain the entitlement to legal protection. Actual control over a thing, and not a right, is therefore protected. For that reason, possession or protection of possession may lead to absurdity. Even a thief enjoys possessory protection, even though his or her possession is vicious. His or her possessory protection is overall not of the same quality as protection given to a bona fide possessor, because in order to avoid excessive legal absurdity, law grants the affected party the objection of vicious possession (see the second paragraph of Article 33 of $\mathrm{SPZ}^{1}$ ).

The complexity of the concept of possession can be understood by examining history. In the past, it was disputed whether possession is a special property right or merely a fact. The understanding of possession as a special (weaker) property right was strongly opposed by Savigny. The opposite view was represented by Ihering, who recognised possession the status of a right. In the course of later developments, an opinion prevailed that possession is not a subjective right but a legally relevant fact. This position is also represented by modern legal doctrine. Even though possession is legally protected, it is not a right. After all, it would be difficult to agree with a position that a thief, who otherwise also enjoys the protection of possession, has the right to possession (Gavella in Gavella, Josipović, Gliha, Belaj, Stipković, 2007: 155).

Article 24 of SPZ defines direct and indirect possession. In accordance with the first paragraph of Article 24 of SPZ, possession is direct actual control over a thing (direct possession). According to the second paragraph of Article 24 of SPZ, possession is also

\footnotetext{
${ }^{1}$ Stvarnopravni zakonik (Law of Property Code) - SPZ (Official Gazette of RS, No. 87/2002 and 91/2013).
} 
held by a person who exercises actual control over a thing through some other person, who has direct possession on the basis of any form of legal title (indirect possession).

Possession is actual control over a thing. Possession is not a right. A right represents legal control over a thing. While the relationship between a possessor and a thing allows the former to use the thing, enjoy it and dispose of it, it is not important if he or she also has the right to use the thing, enjoy it and dispose of it. Actual control over a thing is therefore the external visibility of a thing belonging to a particular person. Possession constitutes one of fundamental components (entitlements) of ownership, which, despite the fact that it only represents actual control over a thing, nevertheless indicates certain belonging of a thing to a person who exercises this actual control. A third party thus also perceives the possessor as a holder of legal entitlement to a thing (appearance of the right; Rechtsscheinsprinzip) (Westermann, Westermann, Gursky, Eickmann, 1998: 365), because possession in legal transactions indicates the existence of certain entitlements to a thing (the publicity function; Publizitätsfunktion). German BGB enacted in $\S 1006$ a presumption under which a possessor of movable thing is also considered an owner of the thing (presumption of ownership; Eigentumsvermutung). This example was followed by SPZ, which stipulates in the second paragraph of Article 11 that the proprietary possessor of movable property is presumed to be its owner. Such regulation represents great advantages for the possessor in petitory judicial proceedings who is not required to prove ownership in his or her role as a defendant, since the plaintiff must prove that he or she is the owner instead (see the second paragraph of Article 92 of SPZ). Such legitimation effect of possession is also the basis for trust that the possessor is an actual owner, upon which bona fide acquisition of ownership of movable property from a non-owner is founded as well (see Article 64 of SPZ).

Possession as actual control over a thing can be exercised in various manners. It is not necessary for a person to be permanently in direct physical contact with the thing to have the status of a possessor recognised by law. This primarily depends on the type of a thing as an object of possession. Possession of immovable property can also be exercised remotely, as long as possession was acquired (act of apprehension) and the possessor is at all times in a position where he or she can exercise possession (Stanković, Orlić, 1989: 36). It is essential, however, that possession is only that relationship of physical control over a thing, which meets the following criteria: external visibility, permanence, exclusivity and accessibility of the thing to its possessor. ${ }^{2}$

Not only does possession indicate the belonging of a things to a person who is exercising possession, but is also legally protected as a bare actual control. A possessor, who does not necessarily even have the right to possess a thing, which applies to both movable and immovable property, may require protection of possession either through self-help (Article 31 of SPZ) or by bringing an action (judicial protection of possession; Article 33 of SPZ). Possessory protection therefore does not protect ownership, as was contrary to

${ }^{2}$ VSL, Decision I Cp 3172/2013, 2. 4. 2014. 
recent understanding of possessory protection argued by Ihering. He claimed that possessory protection aims to protect ownership, because possession is merely a certain state of this ownership, and as such complements the protection of ownership. In contrast to Ihering's opinion, Savigny's position was based on general prohibition of violence or violent (unlawful) exercise of rights. He derived the purpose of possessory protection from general prohibition of violence. Existing states should not be changed arbitrarily (Gavella in Gavella, Josipović, Gliha, Belaj, Stipković, 2007: 159-160).

The owner of a thing is granted both possessory and petitory protection (protection based on a right). Requirements differ for both forms of protection.

\section{Objective conception of possession under SPZ}

Given the fact that in the end a position (which is well established in current legal systems as well) prevailed that possession is not a subjective property right but a legally relevant fact, the doctrine was mainly concerned with determining criteria for distinction between possession and non-possession. Thus, the doctrine, followed by major codifications of civil law (ABGB, BGB, ZGB), formed two conceptions of possession; subjective and objective conceptions of possession.

Article 70 of ZTLR ${ }^{3}$ already chose a more recent conception of possession, in theory also described as objective, which represents a major change for the understanding of possession of a thing on the one hand and holding (detention) of a thing on the other. Sajovic states that the objectification of possession meant "the abandonment of the path of general legal doctrine" (Sajovic, 2000: 33). Finžgar emphasises that, despite the title of modern conception, this conception has no special advantages by itself, and that the classic subjective conception of possession with its consistently implemented duplicity of possession (possession of a thing and possession of a right) is theoretically more elegant (Finžgar 1985: 401). Thus, for example, according to the subjective conception, a tenant is a possessor of a right and on these grounds also enjoys possessory protection of the right, even against the lessor (Klicka in Schwimann, 1998: 80). According to the objective conception, a tenant is a direct possessor of a thing. Even under the subjective conception (which is, for example, adopted under Austrian law) a bare detentor (e.g. an employee in employment relationship) has neither possession of a thing nor possession of a right, and therefore does not enjoy possessory protection, but may only exercise selfhelp against a third party for the possession master (Gschnitzer, 1985: 7).

SPZ also maintained the objective conception of possession. Despite the introduction of concepts of proprietary and non-proprietary possession under Article 27 of SPZ, there

\footnotetext{
3 "(1) Possession of a thing is held by a person who exercises direct actual control over the thing (direct possession). (2) Possession of a thing is also held by a person who exercises actual control over a thing through some other person, into whose direct possession he or she delivered the thing on the basis of usufruct, rental contract, lease, storage, loan or any other legal transaction."
} 
were no significant developments in our conception of possession directed towards the subjective conception of possession. The non-proprietary direct possessor (e.g. tenant) is therefore not a possessor of a right, but remains a possessor of the things over which he or she exercises direct actual control, whilst also recognising higher legal authority of the indirect possessor.

Typical representatives of the objective conception of possession are primarily Germany and Switzerland. Our closest representative of the subjective conceptions of possession, however, is Austrian ABGB. Considering the fact that ZTLR was adopted only in 1980, Slovenia also followed the subjective conception of possession based on legal rules of former ABGB until ZTLR entered into force. This conception has left a permanent mark among Slovenes, as the term possessor was being used as a synonym for the owner in rural areas.

\section{Distinction between subjective and objective conceptions of possession}

Two conceptions have formed in the area of possession. At first, the so-called subjective conception of possession was adopted by law, according to which the possessor is a person who exercises actual control over a thing (corpus possessionis) and who has the intention to hold the thing as his or her own (animus domini or animus rem sibi habendi). Therefore, only actual control on the basis of which the possessor possessed a thing as his or her own was protected. In classical Roman law, the concept of possession was thus understood in connection with ownership (Stanković, Orlić, 1989: 39). Because of this conception, many holders of actual control over a thing were treated merely as holders of the thing (detentors) (Sajovic, 1994, 50: 55). In the later stages of development of Roman law, the so-called quasi-possessio developed, which is related to usufruct and real servitudes. Thus, in addition to possession of a thing, possession of a right also developed in the context of the subjective conception of possession. Possession of a right was based on the fact that someone acts as a holder of usufruct or real servitude, regardless of whether he or she actually is one. Possession of a right was therefore protected following the example of possession of a thing. Possessory protection was thus significantly expanded (Stanković, Orlić, 1989, 40).

When German BGB was created, grounds for subjective justification of possessory states and relationships were abandoned. Objective criteria were shaped, meaning that the path of general legal doctrine, which was based on the subjective conception of possession, was abandoned (Sajovic 1994: 52). ${ }^{4}$ The objective conception, which represents the more recent conception of possession, no longer requires a subjective element (an intention to hold a thing as one's own), and corpus, i.e. actual control over a thing, suffices. The

\footnotetext{
${ }^{4}$ The author also points out that the principle of possession, which was based on animus dominii, was already breached in Roman law. This was the so-called quasi-possessio, which was recognised as possession of a right.
} 
consequence of these defining elements is also the narrowing of subjects who were granted the status of detentors (Sajovic 1994: 54). ${ }^{5}$

According to the subjective conception, for example, a leaseholder could not have a will of the owner, i.e. to hold a thing as his or her own (animus domini or animus rem sibi habendi). It means that he or she was not a possessor of the thing. Under the (objective) conception, which requires only an objective element, i.e. actual control over a thing, a leaseholder is a direct possessor of a thing and is also legally protected as a possessor of a thing. Therefore, the subjective conception, which originates from Roman law (and was also enacted in $\S 309$ of ABGB), ${ }^{6}$ recognised possessory protection of a thing to a smaller circle of persons. This circle is wider under the objective conception, whereas a detentor is the only one without possessory protection, even though he or she also exercises actual control over a thing. According to the objective conception, possessors of things are also detentors under Roman law. This conception is adopted by, for example, German BGB in $\S 854$, Swiss ZGB in Article 919, as well as our legislation (Article 24 of SPZ).

For our law, and therefore for the objective conception of possession, we can find that it no longer recognises the so-called duplicity of possession. There are no longer two types of possession, possession of a thing and possession of a right, since only possession of a thing remains. It appears either as direct possession of a thing or indirect possession of a thing (Finžgar, 1980, 69). In theory, an opinion was also defended that the reason for the abandonment of possession of a right was also the fact that our law does not recognise intangible property, as is the case under Austrian law, which recognises the subjective conception of possession (Finžgar 198: 68). Despite the objective conception of possession, the third paragraph of Article 70 of previously valid ZTLR retained possession of a right in relation to real servitudes, which was accordingly also used for real burdens, with justification that the owner of the dominant thing has no actual control over the thing, which is instead under actual control of the owner of the servient thing (Finžgar, 1980: 69). We cannot agree with this position, because it ignores the states of partial possession and joint possession. SPZ has completely abolished possession of a right, but that does not mean that a person exercising possession, which corresponds to, for example, real servitude, has no possessory protection. ${ }^{7}$ Possessory protection in such case is limited to the part of the thing (e.g. servitude pathway) on which either partial or joint possession is exercised. This means that SPZ "purged" legal regulation of possession by completely abolishing possession of the real servitude right. Such regulation is theoretically more consistent in systems of the objective conception of possession (Gavella in Gavella, Josipović, Gliha, Belaj, Stipković, 2007: 158). Possession of the real

\footnotetext{
${ }^{5}$ Compared to Roman theory, the establishment of the objectified concept of possession resulted in the expansion of possessory states. Possession was recognised for various legal positions of previous holders - detentors.

${ }^{6} \S 309$ of ABGB provides: "A person who exercises control over a thing or keeps it in storage is called its detentor. If a detentor of a things has the will to hold the thing as his or her own, he or she is considered its possessor."

${ }^{7}$ See also VSK, Decision I Cp 741/2014, 13.1. 2015.
} 
servitude right, as established and protected by ZTLR, was primarily intended to protect the (true or quasi) positive (real) servitude of way, the exercise of which also represents the exercise of actual control over a part of the thing. From this perspective, it seems that there really is no need to protect possession of the right of real servitude. With negative real servitudes (e.g. view servitude), there are no outwardly visible objective signs of actual exercise of possession of a thing. ${ }^{8}$ In fact, there is no actual exercise of possession of a thing in such cases (Gavella in Gavella, Josipović, Gliha, Belaj, Stipković, 2007: 158-159). Therefore, if there is no possession of a thing, there is also no possessory protection. This is especially true for the pure objective conception of possession under SPZ. This means that our law grants no possessory protection in relation to the exercise of negative real servitudes. However, it obviously provides petitory protection (protection against immissions, as long as the immissions are prohibited). The fact that possessory protection is not granted in case of negative real servitudes is not considered a shortcoming of our legal system. These forms of possessory protection are in our estimation not even needed. The same position is supported by Slovenian case law. ${ }^{9}$

\section{Definition of direct and indirect possession}

The first paragraph of Article 24 of SPZ defines direct possession as direct actual control over a thing. A direct possessor is therefore a person who exercises physical control over a thing. The exercise of direct physical control over a thing should not be understood too literally. Even if the possessor does not have daily physical contact with the thing, but is in a position where he or she can exercise such possession, he or she is still considered the possessor of the thing (e.g. the owner of a seaside cottage). Possession is therefore not lost merely because it is not being exercised. For example, the owner who temporarily stopped exercising direct actual control over immovable property, because he or she stayed abroad for a few years, did not lose the status of a possessor. Neither did he or she lose the status of a possessor if he or she is temporarily and involuntarily unable to exercise actual control (the fifth paragraph of Article 45 of SPZ).

\footnotetext{
${ }^{8}$ For this reason, it is also not possible to acquire negative real servitudes by prescription (the fourth paragraph of Article 217 of SPZ).

${ }^{9} \mathrm{SPZ}$ abandoned the construction of possession of a right and protection of servitude is no longer possible on this basis. Possessory protection of negative servitude is also not possible under general rules on possessory protection. Possessory protection is based on possession as actual control over a thing. Since the exercise of ownership is an expression of the owner's freedom, the omission of certain acts cannot lead to the conclusion with a sufficient degree of probability on whether such omission is an expression of the manner in which ownership is exercised by the will of the owner, or if the owner is required to act in such manner on the basis of negative servitude. Negative servitude is not exercised by the holder, it contains no positive action and no objectively visible indicators are present on the basis of which its existence could be inferred. Therefore, this situation does not correspond to the general conception of possessory protection (VSL Decision II Cp 6482/2005, 20. 4. 2006; VSL Decision II Cp 6482/2005, 20. 4. 2006; VS, Decision II Ips 669/2007, 10. 1. 2009; VSL, Decision II Cp 4307/2009, 24. 2. 2010; VSL, Decision I Cp 4442/2009, 3. 3. 2010; VSL, Decision I Cp 1336/2010, 21. 4. 2010; VSL, Decision I Cp 844/2010, 12. 5. 2010; VSL, Decision II Cp 1321/2010, 27. 5. 2010).
} 
The second paragraph of Article 24 defines the so-called constructive possession relationship (Schwab, Prütting, 1997, 40; Sajovic, 1994, 81-82) ${ }^{10}$ which is the basis for the establishment of indirect possession. Possession is also held by a person who exercises actual control over a thing through some other person who has direct possession on the basis of any form of legal title ${ }^{11}$ (indirect possession). The provision of the second paragraph of Article 24 of SPZ is in comparison to the provision of the second paragraph of Article 70 of ZTLR less casuistic, as it no longer lists particular legal relationships that are the basis for the establishment of indirect possession. ${ }^{12}$

SPZ no longer contains a provision on possession of servitudes, such as the one from the third paragraph of Article 70 of ZTLR ("Possession of real servitude is held by a person who actually uses another person's immovable property to the extent corresponding to the content of this servitude"). The provision was actually an example of possession of a right, which is not compatible with the objective conception of possession, and was therefore abolished by SPZ, as we have previously stated. A position was adopted that such cases are a matter of possession of a part of the thing as well.

While we can conclude that a detentor is not a possessor, even if he or she exercises actual control over a thing, we can also bring an opposing statement that an indirect possessor does not exercise actual control over a thing, but is nevertheless considered a possessor. This is an example of possession without actual control (spiritualised possession) (Stanković, Orlić, 1989: 37), which also includes possession held by successors (Schwab, Prütting, 1997: 39). An indirect possessor has no direct (outwardly visible) actual control over a thing; actual control is exercised by a direct possessor, personally or through a detentor. An indirect possessor exercises some form of control over a thing, but this is not actual control. His or her control is based on legal relationship with a direct possessor, which is why he or she is recognises the status of a possessor (Schwab, Prütting, 1997: 41). He or she has economic interest to preserve the thing which will later be returned, which is why he or she is granted possessory protection for purely practical reasons as well (Stanković, Orlić, 1989: 37).

${ }^{10}$ German theory uses in this context the term "Besitzmittlungsverhältnis" or a constructive possession relationship as a relationship of direct - indirect possession.

${ }^{11}$ We can see that the existence of some legal relationship between both possessors is needed for the existence of relationship of direct - indirect possession. It is not required that this legal relationship should be valid.

${ }^{12}$ German BGB regulates indirect possession (mittelbarer Besitz) in $\S$ 868: "If a person possesses a thing as a usufructuary, pledgee, lessee, tenant, depositary or on the basis of a similar relationship, and is for the duration of possession entitled or obliged in relation to another person, the other person is also a possessor (mitelbarer Besitz)." A less casuistic definition of indirect possession can be found in Article 920 of the Swiss ZGB: "If a possessor transferred possession of a thing to some other person on the basis of a restricted real right or contractual right, both are considered possessors." 
For a relationship of direct - indirect possession, a will to possess the thing is required (e.g. tenant, lessee, etc.), which in other words means that a direct possessor has to recognise some higher possession (Oberbesitz) of someone else (indirect possessor) (Baur, Baur, Stürner 1999: 64-65). Legal relationships (Westermann, Westermann, Gursky, Eickmann, 1998: 111; Stojanović, Pop-Ggeorgiev, 1980: 159) that establish a relationship of direct - indirect possession are, for example, rental, lease, loan, transport of goods, work contract, mandate, commission, commercial representation, sales order, retention of ownership, fiduciary transfer of ownership (Baur, Baur, Stürner 1999: 67) ${ }^{13}$, etc. In all cases, legal relationship must exist between participants (direct and indirect possessor) (Schwab, Prütting, 1997: 40-41; Westermann, Westermann, Gursky, Eickmann, 1998: 109). This legal relationship does not necessarily also need to be valid. There is obviously no such relationship between the thief and his victim, because legal relationship between them, which is a prerequisite for the relationship of direct - indirect possession, does not exist.

Indirect possession may also consist of several stages (Mehrstufiger mittelbarer Besitz). This happens if more than one person acts as an indirect possessor (not as a joint possessor). Such situation would occur, for example, if a usufructuary left a thing in a third party's possession on the basis of a lease. Both the owner and the usufructuary are thus indirect possessors and the lessee is a direct possessor (Stojanović, Pop-Ggeorgiev, 1980: p. 160; Gavella in Gavella, Josipović, Gliha, Belaj, Stipković, 1998: 116). The second paragraph of Article 30 of SPZ also provides that indirect possession is not lost if the previous direct possessor becomes an indirect possessor. The provision therefore refers to the establishment of multi-stage indirect possession.

\section{$5 \quad$ Acquisition of direct and indirect possession}

The theory distinguishes between original and derivative acquisition of possession (Baur, Baur, Stürner, 1999: 60), but we will mainly focus on derivative acquisition. First and foremost, it should be clarified that conditions for derivative transfer of possession are both the will of the previous possessor to transfer possession (Abgabewille), as well as the will of the acquirer to obtain possession (Erwerbswille). The previous possessor is generally required to also transfer actual control over a thing to the acquirer with a real act (Baur, Baur, Stürner, 1999: 61).

Direct possession is acquired by physically handing over a thing, which occurs as a real actual transfer of the thing (traditio vera) (Westermann, Westermann, Gursky, Eickmann, 1998: 94$)^{14}$ by seizing a thing on the grounds of permission (taking a thing into direct possession in a supermarket, from a vending machine, etc.), by bringing a thing under the

\footnotetext{
13 The fiduciary transfer of ownership (Sicherungsübereignung) represents a non-possessory protection in rem, which establishes a relationship of direct - indirect possession with the effects of possessory agreement.

${ }^{14}$ A physical delivery is called "Realakt" in German theory.
} 
acquirer's actual control (letter that is left in the acquirer's mailbox), by handing over a key, consignment note, storage certificate, by alienating a part of a thing, by separating or otherwise marking a thing, if this means its delivery, etc. (Gavella in Gavella, Josipović, Gliha, Belaj, Stipković, 1998: 137. See Article 34 of ZTLR. See also Stojanović, Pop-Ggeorgiev, 1980: 96; Gavella, 1984, 166-167). The above-described means of acquisition are mainly suitable for the area of movable property. In terms of the acquisition of direct possession of immovable property, the theory also lists as an act of the transfer of possession (in addition to handing over the keys, building a fence, marking, processing, occupying) a contractual provision on the transfer of possession (e.g. on the date of signing of the sales contract) to the acquirer (Stanković, Orlić, 1989: 45). Our SPZ does not contain the explicit provision to this effect, which nevertheless does not mean that it is not possible to transfer possession with the expression of will. This can particularly be derived from the provision of the second paragraph of Article 60 of SPZ, which regulates a symbolic transfer of a thing. Thus, for example, under the second paragraph of $\S 854 \mathrm{BGB}$, an agreement between the previous and the new possessor suffices for the acquisition of possession, if the new possessor is in position to exercise actual control over the thing (Schwab, Prütting, 1997, 30-31). ${ }^{15}$ Such provision is contained in the second paragraph of Article 922 of ZGB as well. This position was also confirmed by our case law: "In regard to the transfer of possession of immovable property on the basis of legal transaction, the will component of the transfer should be considered essential, and the transfer of possession should be recognised even solely on the basis of the agreement on the transfer of possession concluded by the parties, if the acquirer is in position to exercise direct actual control over the thing. Immovable property cannot be handed over into someone's possession in the same way as movable property, and the transfer of possession may thus also be carried out by handing over a key or if the parties declare the will to transfer possession."16

Indirect possession is normally obtained when a direct possessor hands over a thing to another person into direct possession on the basis of a rental, lease, loan, retention of ownership, etc. Indirect possession is also acquired with the transfer of ownership on the basis of possessory agreement - constitutum possessorium (the second indent of the third

15 The second paragraph of $\S$ of 854 BGB: »Die Einigung des Bisherigen Besitzers und des Erwerbers genügt zum Erwerbe, wenn der Erwerber in der Lage ist, die Gewalt über die Sache auszuüben. «A possibility to exercise actual control means that the thing has to be accessible to the acquirer. We can thus also include cases of symbolic transfer of a thing in this regard. Possession is not transferred (despite the agreement), for example, if the previous possessor reserves the possibility to exercise actual control over a thing by keeping the keys and continues to exercise actual control. Thus, the acquirer does not have the possibility to exercise actual control over the thing. Such agreement (Einigung), which is considered by Germans to have the nature of legal transaction and which is subject to all provisions of general part of BGB on legal transactions (Baur, Baur, Stürner, 1999, p. 62), is not an agreement within the meaning of $\S 873$ and $\S 929$ of BGB, which is required for the transfer of ownership of immovable and movable property, but merely an agreement that results in the transfer of possession (Schwab, Prütting, 1997, 31).

${ }^{16}$ VSL, Judgement II Cp 682/2012, 24. 10. 2012. 
paragraph of Article 60 of SPZ) and is transferred to another person on the basis of traditio longa manu (the fourth paragraph of Article 60 of SPZ) (Cf. Baur, Baur, Stürner, 1999: 68). ${ }^{17}$ Therefore, indirect possession can in principle only be obtained with the expression of the will (Gavella in Gavella, Josipović, Gliha, Belaj, Stipković, 1998: 126). A thing is thus generally given into direct possession with the physical transfer and into indirect possession with the expression of the will. There is, however, an example of giving a thing into direct possession with the expression of the will. This happens when a detentor (who already exercises actual control over a thing) hands over the thing into direct possession (traditio brevi manu).

A situation is also not uncommon when direct and indirect possession is acquired at the same time (e.g. a commission agent obtains direct possession of a thing in a commission sale, while at the same time the principal obtains indirect possession) (Gavella in Gavella, Josipović, Gliha, Belaj, Stipković, 1998: 134). It is important whose possessory representative is the person who acquires direct possession of a thing. These are the cases of the acquisition of possession through a representative (see Article 62 of SPZ) (Baur, Baur, Stürner, 1999: p. 80-81). ${ }^{18}$ For example, if a consignor handed things over to a carrier to be shipped to the buyer, whereas he or she enlisted the carrier him- or herself, the buyer will acquire (direct) possession when the carrier actually (or by handing over a consignment note) delivers the thing. If, however, the buyer is the one who enlisted the carrier, he or she (the buyer) will obtain (indirect) possession when things are actually (or by handing over a storage certificate) handed over to the carrier (Gavella in Gavella, Josipović, Gliha, Belaj, Stipković, 1998: 138. See for example Article 923 of ZGB).

Both direct and indirect possession can also be acquired at the time of the decedent's death (the so-called possession by an heir - see Article 29 of SPZ). If the decedent was an indirect possessor, the same form of possession will be inherited by his heirs. If, however, he or she was a direct possessor, the heirs will also become direct possessors at the time of the decedent's death. Therefore, they will obtain direct possession without exercising direct actual control over a thing.

\section{Case law}

\subsection{No possession of a right or negative real servitude}

VSL Decision II Cp 6482/2005, 20. 4. 2006: SPZ abandoned the construction of possession of a right and protection of servitude is no longer possible on this basis. Possessory protection of negative servitude is also not possible under general rules on

${ }^{17} \mathrm{BGB}$ contains a special provision on the transfer of indirect possession with a possessory assignment (i.e. with an assignment of a claim - Herausgabeanspruch) in $\S$ 870: "Indirect possession may be transferred to another person with the transfer of the claim for the delivery of the thing."

${ }^{18}$ Westermann emphasises that a representative (Stellvertreter) may also obtain possession directly for the represented person, if he or she acts as a detentor (Westermann, Westermann, Gursky, Eickmann, 1998: 98). 
possessory protection. Possessory protection is based on possession as actual control over a thing. Since the exercise of ownership is an expression of the owner's freedom, the omission of certain acts cannot lead to the conclusion with a sufficient degree of probability on whether such omission is an expression of the manner in which ownership is exercised by the will of the owner, or if the owner is required to act in such manner on the basis of negative servitude. Negative servitude is not exercised by the holder, it contains no positive action and no objectively visible indicators are present on the basis of which its existence could be inferred. Therefore, this situation does not correspond to the general conception of possessory protection.

\subsection{The manner in which actual control over a thing is exercised}

VSL, Decision II Cp 4172/2009, 20. 1. 2010: Direct actual control over a thing, which must be established for the benefit of a possessor within the meaning of provisions of the first paragraph of Article 24 of SPZ, is not only represented by an outwardly visible active conduct of a possessor who operates with a thing in his possession or joint possession in certain manner, but also by maintaining the thing and preserving it in its intended form on the basis of concluded legal transactions in accordance with provisions of the Housing Act.

VSL, Decision II Cp 43/2010, 18. 2. 2010: Possession of a thing is not any physical relationship between a person and a thing (this is actual manifestation of possession), but actual control over a thing (Article 70 of ZTLR). However, neither is all actual control over a thing considered possession. Possession is only that relationship of physical control over a thing that meets the following criteria: external visibility, permanence, exclusivity and accessibility of a thing to its possessor. Exclusivity means the possibility to exclude third persons from sharing the use of a thing, while accessibility means that the possessor may, whenever he or she wants, always have an option to use or share the use of the thing. The court of first instance found that the parking lot in question was used for parking by third persons and anyone who wanted to do so, since the parking lot was obviously open, which was also reasonably confirmed by appellants in the context of their statements in the appeal. Therefore, the appeal wrongly assessed the fact that other persons could park in the parking lot as irrelevant for the present case. Because of the above-mentioned facts, it is evident that the parking lot in question was not used by a closed circle of persons, but also by unspecified third persons. They were therefore not excluded from the use of the parking lot in question. [Thus: VSL, Decision II Cp 2403/2009, 2. 4. 2010; VSL, Decision I Cp 1336/2010, 21. 4. 2010].

VSL, Decision I Cp 2482/2011, 21. 9. 2011: For possession, it is not necessary that a permanent physical contact exists between a possessor and a thing; it is essential that a possessor always has an option to use and enjoy the thing whenever he wants to do so. It is therefore irrelevant whether the plaintiff used the apartment regularly or only occasionally; the abandonment of possession of the apartment would only be 
demonstrated if the plaintiff carried out all his things, turned in the key of the apartment and abandoned any intention to use the apartment for any purpose.

VSL, Decision I Cp 1246/2012, 17. 10. 2012: Spending one night in an apartment without any personal items does not represent the exercise of possession, which must be, as correctly concluded by the court of first instance, a permanent and externally visible control over a thing.

VSL, Decision I Cp 1246/2012, 17. 10. 2012: The court of first instance took a very thorough approach in determining who had the last possession of the apartment and garage in question. It considers the free disposal with keys of the apartment as one of the essential proofs for possession of the apartment. It also convincingly found that the defendants had keys of the apartment at their disposal until 3. 6. 2011, as they were available in the so-called utility room.

VSL, Judgment I Cp 1081/2012, 17.10. 2012: Appellate position that the defendant acquired possession of movable property in question by obtaining possession of immovable property has no basis. Correct are findings of the court of first instance that these things are not fixtures to immovable property, which was bought by the defendant at public auction, as there is no factual or legal basis for a different conclusion. Therefore, the automatic acquisition of possession of immovable property could not occur. The provision of the first paragraph of Article 24 of SPZ defines direct possession as direct actual control over a thing, which was not exercised by the defendant, as determined in the evidence-taking procedure, because things that were located on immovable property were freely available to any person who wanted to take them away, which has actually been happening - they were being taken away both by the plaintiff and by others. It was also found that the defendant demonstrated no will to take possession of these things, even though it should be noted that the question of the will itself is not decisive, since SPZ follows the objective conception of possession, under which only actual control over a thing is required. However, this can be considered another indication that she did not exercise possession over the things.

VSL, Decision I Cp 3172/2013, 2. 4. 2014: According to legal theory, possession is only that relationship of physical control over a thing, which meets the following criteria: external visibility, permanence, exclusivity and accessibility of a thing to its possessor. In proceedings before the court of first instance as well as in appeal proceedings, the disputed question is whether actual control exercised by the plaintiffs over parking spaces in question meets the criteria listed here. Regarding the issue of exclusivity [of possession], the appellant refers to case law of the Higher Court in Ljubljana; ${ }^{19}$ however,

${ }^{19}$ These are especially the following decisions of this court: I Cp 222/2004, II Cp 2395/2009, II Cp 43/2010, I Cp 377/2010, II Cp 2598/2010, I Cp 4093/2010 and I Cp 392/2011. Appellate statement that the position adopted by the Higher Court in Ljubljana in these decisions holds that "possession 
the court observes that situations addressed in cases referred to by the appellant are not the same as in the present case. A factual and decisive difference exists in the fact that those cases dealt with an alleged disturbance within the circle of joint possessor, and the present case did not; but also in the fact that the plaintiffs in the cited cases generally did not acquire a parking space in disputed parking lots even before the disturbance. The decision of the court of first instance therefore does not represent the derogation from case law of this court but different legal and factual situation.

The discussed case is similar in its essential elements to cases of the same court I Cp 1692/2011 and I Cp 2794/2012, and to some extent also to the situation in Decision II Cp 2613/2009, which complied with claims for disturbance of possession.

Additionally, in terms of the issue of exclusivity, the appellate court points out that this criterion truly implies the possibility that the possessor excludes third persons from interfering with a thing. However, in assessing this issue, the court must always be cautious - this is not a possibility to exclude any influences, but only those that are according to our current understanding in life and in legal transactions considered to represent the negation of actual control of the possessor of a thing. This exact assessment demonstrates that all the cases examined by the Higher Court in Ljubljana and referred to by the appellant are fundamentally not the same. Statements or findings that other persons parked in disputed areas (when the residents were not there), whereas the court of first instance did not find the plaintiffs to ever have a problem with parking for that reason, absolutely cannot mean that the condition of exclusivity does not exist. If people who go to work or run errands park in a certain parking lot in the morning (when residents are not using parking spots, because they drove away to work), and residents park there in the afternoon, the conduct of the former in no way negates actual control over a thing. For the sole reason that they were recognised the status of possessors by law, the first group (i.e. residents) is not required to prevent in uncivilised manner third persons from using the thing, when they do not even need it themselves.

\subsection{Periodic exercise of possession}

VSL, Decision I Cp 3828/2009, 24. 2. 2010: The plaintiff was using the pathway, which is the subject of this possessory dispute, when he or she went to harvest wheat with a combine harvester. Since the plaintiff rotates crops, this happened every two years. Therefore, this was a periodic exercise of actual control over a thing for a specially designated purpose and to the described extent. The appellate court agrees that in the present case, this corresponds to the standard of possession within that extent (Article 24 of SPZ).

of the parking lot in the immediate vicinity of the building is not possible" is wrong, torn out of context and incorrect. 


\subsection{Indirect possession}

VSL, Decision I Cp 4386/2010, 8. 6. 2011: Definition of possession, and thus of the possessor who holds possession, is provided by Article $24 \mathrm{of} \mathrm{SPZ,} \mathrm{which} \mathrm{stipulates} \mathrm{that}$ possession of a thing is held both by a person who exercises direct actual control over a thing (direct possession - the first paragraph) as well as a person who exercises actual control over a thing through some other person, who has direct possession on the basis of any legal title (e.g. usufruct, rental contract, lease, storage, loan, or any other legal transaction).

\subsection{Possession of electricity, water}

VSL, Decision I Cp 4353/2009, 3. 2. 2010: While the plaintiff truly did not expressly request possessory protection of the apartment but possessory protection of the use of electricity in the apartment, she has in effect requested the undisturbed use of the apartment in which electricity is available, as already noted by the court of first instance. Considering the whole of her statements and conclusions from the contested decision, her assertion of possession of the use of electricity in the apartment should be understood as an assertion of possession of the apartment. Imprecise expression or somewhat crude claim of the plaintiff does not mean that the court of first instance grants possessory protection to the use of electricity, but it concerns an apartment in which electricity is being used. Possessory protection is granted to the apartment as an object that can be used in accordance with its purpose only if it is supplied with electricity. Otherwise, its use is effectively prevented and possession of the apartment as a thing is certainly disturbed. The possibility to use the apartment is also exactly the purpose of its possession, while the prevention of the use of a thing in accordance with its function consists disturbance of possession of the thing itself. The prevented use of electricity is therefore an interference with possession of the apartment, because the apartment thereby lost its basic function.

VSL, Decision I Cp 1266/2010, 20. 4. 2010: According to the provision of Article 24 of SPZ, possession is direct or indirect actual control over a thing. Since water is not a thing that could be held in possession, possessory protection of water is realised by requesting possession of things in which water is used, for example, in the building or land. The plaintiff in the present case exercises possessory protection of the use of water from the second indent of the operative part of the decision in exactly such manner. A condemnatory part of the claim in possessory dispute represents the essence of possessory protection and contains a request for possessory protection of the plaintiff's water pipes, leading to his plot no.... 


\subsection{Possession of parking areas}

VSL, Decision I Cp 4093/2010, 18. 5. 2011: Residents of apartment buildings do not have possession of parking areas in front of apartment buildings, which are accessible to anyone. Parking depends on the available parking space.

VSL, Decision II Cp 3200/2011, 22. 2. 2012: Following the findings that the defendant sabotaged five to seven parking spaces with his conduct, but that thirteen parking spaces are still available, the conclusion of the court of first instance that the plaintiff was not disturbed in his possession of parking is correct. The plaintiff already parked there only when parking spaces were unoccupied. The plaintiff did not have such possession of the parking lot, which would exclude others from parking, which would have guaranteed a certain number of specifically designated parking spaces. Only such possession would grant possessory protection in case of the defendant's interference.

VSL, Decision I Cp 1489/2012, 12. 9. 2012: The appellant further argues that the use by other persons (W., B., S.) demonstrates a discontinuous use of a thing by the respective plaintiffs. The answer is that in the assessment of the fact whether the plaintiffs exercised possession of the disputed parking lot (which the appeal does not even contradict) and whether it was exercised regularly, a comprehensive, convincing and accurate evaluation of evidence was conducted (page 8 and 9 of the contested judgement) for each of the plaintiffs who succeeded with their claim. The court of second instance refers to this assessment in order to avoid repetition and agrees with conclusions. The appellate court has already explained in its prior repealing decision that if conditions of exclusivity and accessibility were interpreted too strictly, no one would be entitled to possessory protection, and the institution itself would thus lose its meaning, and that it is normal for the parking lot to even remain empty during the day, because residents go to work and run errands, and even if in the meantime the residents do not park in these spaces, this does not mean that the plaintiffs cannot be possessors of the parking lot, all of which represents a response to the (repeated) appellant's statements.

VSL, Decision I Cp 3172/2013, 2. 4. 2014: The court of first instance found in the contested decision that immovable property in question consists of parking lots along the road, which have been used by residents of apartment buildings G. 9, 11 and 13 since 1971. Based on the plaintiffs' hearing, the court of first instance found that before disturbance of possession at issue occurred, they used to park in this parking lot, referred to as "parking lot across the street," "where the puddle is located," "in the puddle," or parking lot "in front of the lawn" or "behind the lawn," or "there with the three lanes" or "there on the other side of the lawn in the third row, where the puddle is located." All plaintiffs coherently stated that before the alleged disturbance occurred, they generally always found an unoccupied parking space in the disputed parking lot. They parked either in front of the apartment building or in the disputed parking lot, which some of them considered equivalent to parking in front of the apartment building, while others 
considered it an alternative space if they failed to find a space in front of the apartment building.

Following such evidentiary conclusion of the court of first instance, the appellate court accepts the ensuing findings of the court of first instance that the plaintiffs (as well as other residents of G. Street) were holders of joint possession of parking spaces in question. Their physical control over disputed immovable property was externally visible, permanent and exclusive - possessors always had access to the thing.

\subsection{Transferring possession of immovable property}

VSL, Decision II Cp 682/2012, 24. 10. 2012: By pointing out the fact that the donor handed the key of the apartment building to the plaintiff's legal predecessor and contractual provision on the transfer of possession, the appellant justifiably objected to conclusions of the first court relating to possession. In the transfer of possession of immovable property on the basis of legal transaction, the will component of the transfer should be considered essential, and the transfer of possession should be recognised even solely on the basis of the agreement on the transfer of possession concluded by the parties, if the acquirer is in a position to exercise direct actual control over the thing. Immovable property cannot be handed over into someone's possession in the same way as movable property, and the transfer of possession may thus also be carried out by handing over a key or if the parties declare the will to transfer possession. 


\section{Joint Possession}

\section{In general}

Possession may be exercised by more than one person either by them possessing the thing together or by each of them exclusively possessing a specific part of the thing (Article 25 of SPZ).

Possession of a things can thus be exercised by more than one person (joint possession). The provision of Article 25 of SPZ carries a title of marginal section joint possession, even though it essentially refers to two different forms of the exercise of actual control over a thing. Only when multiple persons jointly exercise possession of a thing, so that each joint possessor may exercise actual control over the entire thing, may we speak of joint possession (Mitbesitz). When multiple persons exercise possession so that each of them holds possession only of a certain part of the thing, this is a case of partial possession or exclusive possession of a part of the thing (Teilbesitz). ${ }^{1}$

SPZ completely abolished possession of a right, but that does not mean that the holder of possession, which corresponds to, for example, a real servitude, has no possessory protection. Possessory protection in such case is limited to a part of the thing (e.g. servitude pathway) of which either partial or joint possession is being exercised. This means that SPZ "purged" legal regulation of possession by completely abolishing possession of the real servitude right. Such regulation is theoretically more consistent in systems with the objective conception of possession (Gavella in Gavella, Josipović, Gliha, Belaj, Stipković, 2007: 158). Possession of the real servitude right, as established and protected by ZTLR, was primarily intended for the protection of (true or quasi) positive (real) servitudes of way, the exercise of which also represents the exercise of actual control over a part of the thing. From this perspective, it seems that there really is no need to protect possession of the real servitude right. With negative real servitudes (e.g. view servitude), there are no outwardly visible objective signs of actual exercise of possession of a thing. ${ }^{2}$ In fact, there is no actual exercise of possession of a thing in such cases at all (Gavella in Gavella, Josipović, Gliha, Belaj, Stipković, 2007: 158-159). Therefore, if possession of a thing does not exist, there is also no possessory protection. This is especially true for the pure objective conception of possession under SPZ. This means that our law grants no possessory protection in relation to the exercise of negative real servitudes. However, it obviously provides petitory protection (protection against

\footnotetext{
${ }^{1}$ See also $\S 865$ (Teilbesitz) and $\S 866$ (Mitbesitz) of BGB.

${ }^{2}$ For this reason, it is also not possible to acquire negative real servitudes by prescription (the fourth paragraph of Article 217 of SPZ).
} 
immissions, as long as the immissions are prohibited). The fact that possessory protection is not granted in the case of negative real servitudes is not considered a shortcoming of our legal system. These forms of possessory protection are in our estimation not even needed. The same position is supported by Slovenian case law. ${ }^{3}$

\section{Joint possession}

In terms of joint possession, German legal theory, for example, also differentiates between common joint possession and ordinary joint possession. In common joint possession, joint possession can be exercised only by all joint possessor together. An example would be a situation where a person A is only able to open a bank safe deposit box together with a bank employee, who also has his own key, and the safe deposit box can be opened only with both keys. An example of ordinary joint possession would be a situation where multiple persons exercise actual control independently, but alongside each other. Joint possession of spouses who have common ownership of a thing is another example of ordinary joint possession. Joint possession may also occur in the form of either direct or indirect possession. ${ }^{4}$ If, for example, spouses, who are ordinary joint possessors of an apartment, rent this apartment to a person A, then the person A is considered a direct exclusive possessor of the apartment and the spouses are indirect ordinary joint possessors of the apartment (Wolf, 1999: 82-83).

Joint possessors also enjoy possessory protection, both within their mutual relationship, as well as against third parties. In relations between two or more possessors of the same thing, any action which arbitrarily alters or hinders the way in which possession has been exercised until that point shall be considered to be a disturbance (see Article 35 of SPZ).

\section{$3 \quad$ Partial possession}

Possession can be limited to a certain part of the thing. If, for example, the possessor exercises possession of a particular area of the apartment or house (of one room), this is partial possession. Despite the fact that such part of the thing cannot be subject to ownership, because it is not an independent thing, it can be subject to partial possession. The principle of speciality in property law (Article 7 of SPZ) therefore does not apply to states of possession. Thus, for example, a subtenant could be a direct partial possessor of only one room in the apartment, a tenant a direct partial possessor of other rooms, and both of them could be ordinary joint possessors of shared areas (hallway, bathroom ...). At the same time, the tenant is also an indirect possessor of the sublet room. If partial possession is exercised by multiple persons together, they are generally ordinary joint

\footnotetext{
${ }^{3}$ VSL Decision II Cp 6482/2005, 20. 4. 2006; VS, Decision II Ips 669/2007, 1.10. 2009; VSL, Decision II Cp 4307/2009, 24. 2. 2010; VSL, Decision I Cp 4442/2009, 3. 3. 2010; VSL, Decision I Cp 1336/2010, 21. 4. 2010; VSL, Decision I Cp 844/2010, 12. 5. 2010; VSL, Decision II Cp 1321/2010, 27. 5. 2010.

${ }^{4}$ The direct and indirect possessors of a thing are not joint possessors.
} 
possessors in terms of their mutual relationship. An example would be a situation where spouses live in the same building with parents, in which they share possession with parents, but the spouses jointly exercise possession (i.e. joint possession) of a part of the thing.

Each partial possessor enjoys possessory protection on the part of the thing in his partial possession, both against third parties, as well as in relation to the other partial possessor (Wolf, 1999: 82).

\section{Multiparty states of possession that correspond to states of ownership}

Co-ownership and joint ownership correspond to the largest extent to ordinary joint possession, if no agreement exists between co-owners and joint owners on a different manner of the exercise of possession. Thus, co-owners or joint owners may change joint possession into partial possession with an agreement. For example, spouses, who are coowners or joint owners of a two-floor apartment building, agree to divide joint possession so that each of them will exclusively exercise possession of a part of the building. This will not change the state of ownership, but will only change the type of possession and therefore the manner of the exercise of actual control over a thing.

Although common joint possession grammatically invokes associations with joint property, there is no such correspondence. A special feature of common joint possession lies in the fact that it can only be exercised jointly by all possessors (an example of a bank safe deposit box with two keys that can only open the safe deposit box together and at the same), while common owners exercise actual control in the form of ordinary joint possession or in the form of partial possession.

\section{Legal effects of the agreement on the use of a thing (on the exercise of possession of a thing)}

The seventh paragraph of Article 67 of SPZ provides that resolutions adopted by coowners concerning the management of a thing also have the effect of benefiting and burdening the legal successors of an individual co-owner. The management of a thing also encompasses the determination of the manner of use of the thing or an agreement on the exercise of possession of a thing (see the fifth paragraph of Article 67 of SPZ).

If, for example, co-owners agree that one co-owner may use immovable property without charge to the extent that exceeds his co-ownership share, this agreement has in relation to the co-owner who agreed to such use, as well as to his singular or universal legal successor, characteristics of precarium relationship, which can be revoked at any time by a new co-owner or a new acquirer of co-ownership share (Cf. the third paragraph of Article 583 of OZ). However, if a paid use was agreed to the extent that exceeds the share in ownership, the agreement has characteristics of a lease relationship, which under a special provision of Article 610 of $\mathrm{OZ}$ also binds a new acquirer of ownership, even if he 
or she had no knowledge of the existence of such relationship. In this context, case law even argued that an agreement on the management of a co-owned thing has no absolute effects, insofar as it relates to the use of the thing in kind. ${ }^{5}$ In our opinion, this position is incorrect. If, for example, co-owners agree to use and thereby exercise possession of a thing, which corresponds to the extent of co-ownership share, such arrangement has under the express provision of the seventh paragraph of Article 67 of SPZ not only relative but also absolute effect. It means that the agreement also has the effect of benefiting and burdening the co-owner's (possessor's) legal successors. An example would be a situation where co-owners with equal shares (each co-owner owns $1 / 2$ of the whole) divide the exercise of possession of a plot of land covering $1000 \mathrm{~m}^{2}$ so that each co-owner (partial possessor) exclusively uses $500 \mathrm{~m}^{2}$ of the plot.

A person who is not using co-owned immovable property or is not using it proportionally to his or her co-ownership share (is using it to a lesser extent than he or she is entitled to considering the size of co-ownership share) is entitled to remuneration (compensation for unjustified use of a foreign thing), wherein in accordance with case law and legal theory, the claim is based on the provision of Article 198 in connection with Article 190 of OZ, but only on condition that the person who is not (jointly) using immovable property demonstrates his own deprivation which corresponds to the enrichment of the other party. According to the established case law, "a user charge" is equal to the amount of average market rent (II Ips 589/2008, 10. 9. 2008, II Ips 852/2007, 5. 11. 2009, II Ips 974/2008, 9. 2. 2012).

\section{Case law}

\subsection{In general}

VSL, Decision I Cp 4722/2010, 6. 1. 2011: Joint possession exists when multiple persons jointly exercise possession of a thing, so that each of them exercises actual (integral) control over the entire thing, or if each of them exercises possession of a particular part of the thing. The manner and extent of the use of immovable property by the third defendant does not constitute joint possession of her immovable property, but instead corresponds to the content of real servitude. They can therefore be granted possessory protection only to the extent of the alleged actual exercise of walking and driving for the

\footnotetext{
${ }^{5}$ VSL, Judgement II Cp 2952/2013, 9. 4. 2014: The seventh paragraph of Article 67 of SPZ provides a special exception from the principle of relativity (only) for decisions on the management of a coowned thing .It is thus stipulated that resolutions adopted by co-owners concerning the management of the thing also have the effect of benefiting and burdening the legal successors of an individual co-owner. Such provision is understandable, because the management of a thing allows that thing to better serve its purpose, and it is therefore necessary for new acquirers to enter into legal position of their predecessors in relation to the management of a co-owned thing in order to ensure the normal functioning of the co-owned thing, or to prevent one of co-owners from disposing of his or her share of a thing in a manner that would hinder its effective management. This purpose cannot be attributed to the agreement on the bare physical division of a co-owned thing.
} 
alleged needs of their immovable property. The alleged walking and driving on the pathway is thus something less in relation to joint possession.

VSL Judgement I Cp 179/2010, 21. 4. 2010: Co-owners can use (possess) the co-owned thing so that each of them exclusively exercises possession only of a certain part of the thing (shared possession) or so that all of them exercise possession simultaneously simultaneous possession (Article 25 of SPZ), while a combination of both is also possible. The decisive factor is the will of co-owners, whereby it is not necessary that the manner of use/possession corresponds to legal ratio of ideal shares. Even if the manner in which possession is being exercised does not correspond to the ratio of ideal shares, a co-owner, who exercises possession of a thing to a lesser extent than he is entitled to, may not arbitrarily change the existing manner of the exercise of possession, but may require that the court determines such proper (corresponding to his co-ownership share) use on the basis of his co-ownership rights.

\subsection{The agreement on the use of a thing}

VS, Judgement II Ips 836/2009, 8. 4. 2010: The very nature of co-ownership (which is a divided ownership of an undivided thing; the thing itself is not divided) therefore generally requires certain communication of co-owners regarding co-ownership of a thing, which is ultimately also evident from the cited statutory provisions. Thus, the most common are agreements on the regulation of relations between co-owners (use, enjoyment and management) as well as agreements on the division of a thing. The agreement on the regulation of relations between co-owners is a legal transaction (a contract), with which co-owners generally agree on (joint) possession, (joint) use and management of the co-owned thing, while the thing remains undivided. Where the nature of a thing allows for such agreement, they may agree that each of them claims and uses only a part of the thing - a part of immovable property, individual plot, etc. (...) For the agreement on the manner of use of co-owned immovable property, an oral (informal) agreement is sufficient.

VSL, Judgement II Cp 2952/2013, 9. 4. 2014: The seventh paragraph of Article 67 of SPZ provides a special exception to the principle of relativity (only) for decisions on the management of a co-owned thing. It is thus stipulated that resolutions adopted by coowners concerning the management of the thing also have the effect of benefiting and burdening the legal successors of an individual co-owner. Such provision is understandable, because the management of a thing allows that thing to better serve its purpose, and it is therefore necessary for new acquirers to enter into legal position of their predecessors in relation to the management of a co-owned thing in order to ensure the normal functioning of the co-owned thing, or to prevent one of co-owners from disposing of his or her share of a thing in a manner that would hinder its effective management. This purpose cannot be attributed to the agreement on the bare physical division of a coowned thing. 


\section{3 "Possession of servitude" is actually joint possession of a servient estate}

VSL, Decision II Cp 6482/2005, 20. 4. 2006: SPZ abandoned the construction of possession of a right and protection of servitude is no longer possible on this basis. Possessory protection of negative servitude is also not possible under general rules on possessory protection. Possessory protection is based on possession as actual control over a thing. Since the exercise of ownership is an expression of the owner's freedom, the omission of certain acts cannot lead to the conclusion with a sufficient degree of probability on whether such omission is an expression of the manner in which ownership is exercised by the will of the owner, or if the owner is required to act in such manner on the basis of negative servitude. Negative servitude is not exercised by the holder, it contains no positive action and no objectively visible indicators are present on the basis of which its existence could be inferred. Therefore, this situation does not correspond to the general conception of possessory protection.

VS, Decision II Ips 669/2007, 1. 10. 2009: Possessory protection of servitudes under the currently valid SPZ is truly not (no longer) based on the construction of possession of a right. SPZ thus contains no provisions on possession of (real) servitude, such as the one from the third paragraph of Article 70 of the previously valid ZTLR; under SPZ, these are cases of (joint) possession of a (certain) part of the thing (Article 25 of SPZ). Therefore, (even) a holder of servitude has (may have) the status of a possessor (the first paragraph of Article 24 of SPZ) and is to that extent granted possessory protection even against the owner of servient immovable property, who also exercises possession of the latter.

VSL, Decision II Cp 4307/2009, 24. 2. 2010: SPZ no longer recognises possession of a servitude right, which was regulated by the previously valid ZTLR. In the operative part of the judgement, the court of first instance used a diction "joint possession of the servitude pathway" only to precisely determine the part of immovable property of which the plaintiffs exercised undisturbed possession, and did not establish possession of a right, as was mistakenly claimed by the appellant. Although the exercise of possession is only impeded and not entirely impossible, economic interest to bring an action for the disturbance of possession nevertheless exists. Disturbance of possession is any conduct which hinders or interferes with the exercise of possession.

VSL, Decision I Cp 4442/2009, 3. 3. 2010: The prohibition of driving, expressed by the defendant either orally (in the letter in Annex A6 of 13.9.2007) or by placing various objects on the pathway, contrary to the appellate statements does not deprive the plaintiff of possessory protection (a similar position was also adopted in decisions VSL Decision II Cp 1451/2009 and VSL Decision II Cp 1648/2000). The question of whether the plaintiff has been driving on the pathway, after the defendants began to protest her driving, with the defendant's knowledge or in secret, as claimed by the appeal (which was otherwise not confirmed in the evidence taking procedure), does not change the fact that she had (joint) possession of the pathway, and is therefore entitled to possessory protection. Correct is the opinion of the court of first instance that the defendants may 
only file an action for the disturbance of ownership against the plaintiff, if they believe that she has no (servitude) right to drive on their land. Considering the limited objections in possessory proceedings (the first paragraph of Article 32 of SPZ), they cannot succeed in the present case by claiming that she has no right to drive on the pathway. The appeal does not explain why such position should be considered mistaken.

VSL, Decision I Cp 1336/2010, 21. 4. 2010: SPZ abandoned the conception of possession of a right, and protection of servitude is no longer possible on these grounds. What was allowed under ZTLR in terms of possessory protection of servitudes is no longer provided by SPZ; therefore, the court of first instance is not required to take a position on such possessory protection. The institution of the protection of joint possession is presently comparable to possessory protection of servitude in terms of its contents (Articles 25 and 35 of SPZ). The court of second instance focused on the concept of joint possession, not partial possession, which is an exclusive possession of a particular part of the thing, which is not applicable in the present case. Joint possession is protected in the same way as possession. To succeed in the proceedings, the party must prove requirements for possessory protection, not the content of real servitude as a right. For that reason, it can be concluded that the court of first instance unnecessarily explained how the defendants failed to exercise possession to the extent of real servitude of "a right of way".

VSL, Decision I Cp 844/2010, 12. 5. 2010: The plaintiff stated in the claim that the defendant's conduct resulted in disturbance of his possession of a particular part of the plot no. 206, c.c. S, which represents the existing access road to his land, by preventing his uninterrupted daily use of the access road and his free movement on the road. Regarding such description of the act and subject of disturbance, he requested the restoration to the previous state and the prohibition of future interference. The meaning of the concept of uninterrupted use of the access road and free movement on the road can be derived from the statements in the action. In accordance with provisions of SPZ, the plaintiff did not request the protection of specifically defined possession of the right of servitude (as it would have been claimed under previously valid provisions of ZTLR), but possessory protection of a certain part of the land. Thus, the consequence of disturbance of the plaintiff's possession, determined in the claim, which resulted in the prevention of his uninterrupted daily use of the access road, also includes the use of this access road in the previously established manner in terms of parking and especially turning on this access road. Considering the factual findings that as a result of the disturbance, the plaintiff was prevented from parking and especially from turning on the access road, which he was able to do before the disturbance, it is clear that the plaintiff justifiably claims the protection of his possession of the existing access road, which was disturbed as a result of the defendant's conduct, and that he also demonstrates the necessary legal or economic interest for possessory protection.

VSL, Decision II Cp 1321/2010, 27. 5. 2010: SPZ abandoned the conception of possession of a right, and protection of servitude is no longer possible on these grounds. 
R. Vrenčur: Joint Possession

Correction of the motion, wherein the claimant redrafted the motion by referring to disturbance of possession instead of the original right, is not an amendment of the claim. 


\section{Holding (Detention)}

\section{$1 \quad$ In general}

A person who exercises actual control over a thing for another person and is obliged to act in accordance with that person's instructions does not have possession (is a so-called holder) under Article 26 of SPZ. Regardless of the fact that a detentor is not a possessor, he or she may exercise self-help for the possessor.

A detentor is a person who exercises actual control over a thing for another person and is also obliged to follow his or her instructions. Detention - holding only denotes a certain authorising relationship with a thing. In these cases, the possessor is a person under whose instructions the detentor acts and operates. Evidently, the detentor exercises actual control over the thing, but on the basis of a special relationship, which is also the reason why he or she is not granted possessory protection by law. A typical example of a detentor is, for example, a salesperson in a store. A detentor is not entitled to possessory protection. The first paragraph of Article 26 of SPZ thus defines a detentor in the following manner: "A person who exercises actual control over a thing for another person and is obliged to act according to his or her instructions is not a possessor (a detentor)." Therefore, a detentor him- or herself has no possessory protection, although he or she is allowed to exercise self-help under the explicit provision of the second paragraph of Article 26 of SPZ, but only for the possessor (the so-called possession master). ZTLR contained no such explicit provision on the detentor's exercise of self-help for the possessor, but this option was nevertheless supported by domestic legal theory (Stojanović, Pop-Ggeorgiev, 1980: 170). ${ }^{1}$ The purpose of the provision on the possibility to exercise self-help lies mainly in the fact that the person exercising self-help should be the person who is in the closest physical contact with the thing. Self-help is the most direct form of extrajudicial protection of possession, which can be most effectively exercised by a person who has a direct physical contact with the thing. E.g. a direct possessor of a forklift is the legal person who employs the worker (forklift operator). If someone tried to unlawfully seize the forklift, the forklift operator would often be the one to exercise self-help in order to prevent deprivation of possession.

A detentor exercises actual control over a thing, but is nevertheless not a possessor (Schwab, Prütting, 1997: 36). ${ }^{2}$ There are two basic requirements to determine holding:

\footnotetext{
${ }^{1}$ Our theory also granted self-help to a detentor, if it was exercised for his or her master.

${ }^{2}$ It is clear that the existence of detention presupposes the existence of possessory master's possession as well.
} 
(1) that a certain person exercises actual control for another person, and (2) that actual control is exercised on the basis of, for example, employment or similar relationship, or is exercised in a household, and that an obligation exists to act according to someone else's instructions (possessor) (Schwab, Prütting, 1997: 34). According to German doctrine and case law, a relationship of social dependency and subordination, i.e. some form of "obedience", must exist between the possession master (Besitzherr) and the detentor (Besitzdiener), who represents the interests of the possession master. This dependence must be externally detectible. Such is, for example, a relationship of: household staff (cleaning lady, cook, babysitter); workers, apprentices and other employees in a company; as well as public employees, such as officials, police officers, soldiers (e.g. in terms of uniforms and weapons). Persons listed above will also pursue their own interests, in addition to the interests of others; e.g. a soldier in a company apartment will be a direct possessor in relation to this apartment (that he or she is renting) (see also Schwab, Prütting, 1997: 35).

A purely economic dependence is not sufficient to identify the relationship possessor detentor. When exercising actual control over a thing, a detentor should act as the master's (possessor's) instrument, who cannot proceed without the master's instructions with regard to the thing. In the relationship master - detentor, the master should be considered a direct possessor, as he or she is deemed to exercise direct actual control over a thing (which is otherwise exercised through the detentor) (Westermann, Westermann, Gursky, Eickmann, 1998: 80-81; see also Stojanović, Pop-Ggeorgiev, 1980: 164). An independent position is exactly that essential component which separates a detentor from a direct possessor (e.g. a tenant in a relationship of direct - indirect possession).

\section{$2 \quad$ Is the holder of precarium a detentor?}

Precarium is generally a special type of loan, where the use of a thing is permitted until revocation thereof (the so-called optional loan until revocation). This means that the grantor of precarium (lender) may at any time request the holder of precarium (borrower) to return the thing. The revocability of a relationship is essential for precarium. The revocability of a relationship does not necessarily need to be explicitly agreed upon, it is sufficient that it can be inferred from the circumstances of the case. If, for example, A permits B to temporarily park his car on A's land, it can be assumed from the nature of such relationship that this is the authorisation to use a part of foreign immovable property until the revocation. Both movable and immovable things can be subject to optional loan (precarium). However, it is not a case of precarium, if an owner reserves the possibility to request the return of a thing at any time, while a time limit for the vacation of premises (e.g. 2 months) is also determined for the benefit of the person entitled to use the thing. Another basic feature of precarium as a special type of loan is a gratuitous transfer of the use of a foreign thing. Even if the use is not gratuitous, this is not considered a precarium relationship under Austrian case law. However, the charge for the use must be negligible in comparison with the economic value of the use of a foreign thing (e.g. $10 \%$ of customary rent). This means that even in such case, the gratuity of the use of a foreign 
thing still prevails. The Austrian Supreme Court (OGH) adopted a position in a case of judicial review that, among other things, the question of whether the case represents rental, loan or precarium (optional loan until the revocation) (Schubert in Rummel et al., 2000: 1972- 1973), is a legal question and not a question of fact. The decision is also interesting because it lists typical legal relationships, the possible existence of which should be examined in order to determine the type of legal relationship in a particular case (Schubert in Rummel et al., 2000: 1973).

According to some theorists, a holder of precarium is also considered a detentor (Gavella in Gavella, Josipović, Gliha, Belaj, Stipković, 1998: 115). This would mean that a holder of precarium does not have possession either, and therefore cannot exercise possessory protection, either for him- or herself, against third persons, or against the possession master. According to Austrian case law and opinions found in legal theory, a holder of precarium does not exercise possession of a right in relation to a grantor of precarium, but is a possessor of a right in relation to third parties (Spielbüchler in Rummel et al., 2000: 474). As concerns Austrian regulation of possession in terms of the subjective conception, it should be clarified that a non-proprietary possessor of a thing is considered a possessor of the thing, while a detentor is not even a possessor of a right. We can draw a conclusion, which would also most strongly correspond to the legal nature of precarium, that while precarium is a relationship similar to holding, it nevertheless differs from pure holding. The revocability of a relationship by itself does not create the situation of social dependence of the holder of precarium towards the possession master. However, as the relations is nonetheless quite specific due to its revocability and thus "fragility", the holder of precarium should in our opinion also be denied the status of a possessor in relation to the grantor of precarium. In relation to third parties, he or she should be granted possessory protection, both judicial and self-help.

Precarium is also regulated by our legislation, namely in the third paragraph of Article 583 of OZ, under loan. If the duration and purpose of the use of a thing are not specified, the lender can request the thing whenever he or she wants. A similar provision is found in $\S 974$ ABGB (Binder in Schwimann, 1997: 648-649). ${ }^{3}$ Before the adoption of the new OZ, our case law understandably referred to the p.p. of $\S 974 \mathrm{ABGB}^{4}$ and some others to justify precarium, as ZOR did not regulate the loan contract, in the context of which is the third paragraph of Article 583 of OZ, which is the basis for precarium in our legal system.

\footnotetext{
${ }^{3}$ Theory attempts to differentiate between the so-called contractual precarium and non-contractual precarium (e.g. pathway permitted until revocation, when this is more of a favour than a contractual obligation), wherein a holder of contractual precarium should be granted possessory protection, while a holder of non-contractual precarium should not be granted such protection (see also Cigoj, 1989, 222-223).

${ }^{4}$ See, for example, VS RS, Judgement II Ips 458/95, 18. 9. 1997.
} 


\section{Protection of holding}

In terms of the protection of possession, a detentor is not entitled to any possessory protection. He or she is not a possessor. A detentor has no possessory protection against his or her possessor or against third parties. However, he or she does have the right to self-help (Selbshilferecht) (Schwab, Prütting, 1997: 54) under the explicit provision of the second paragraph of Article 26 of SPZ, which may be exercised for the possession master (Schwab, Prütting, 1997: 36).

Under the provision of $\S 860 \mathrm{BGB}$, a detentor is permitted to resort to self-help as well, which is also specifically provided for a possessor in $\S 859$ BGB. According to our previous regulation in ZTLR, self-help was legally provided only for a possessor (Article 76 of ZTLR). In the second paragraph of Article 26, SPZ explicitly regulated this possibility for a detentor as well. Nevertheless, a detentor is entitled to self-help against his master.

Furthermore, the presumption of ownership under Article 11 of SPZ does not apply to a detentor (Baur, Baur, Stürner 1999: 72; Westermann, Westermann, Gursky, Eickmann, 1998: 81).

\section{$4 \quad$ Holding as the appearance of ownership}

A detentor is not a possessor, which is why the owner is not transferring a thing into his possession, but into holding. Therefore, he or she does not represent his own interests in relation to a thing, but interests of another person (interests of the master). German theory notes that a situation is possible where a detentor starts to arbitrarily use the thing transferred into holding, i.e. in his own interest and on his own behalf, thus becoming a direct, but mala fide, possessor of the thing. Such act represents deprivation of possession from the previous master, as a consequence of which the master is entitled to self-help, as well as to an action for possessory protection.

If a detentor alienates a thing, a third person, who is a bona fide acquirer, cannot obtain ownership on the basis of Article 64 of SPZ (Schwab, Prütting, 1997: 36; Baur, Baur, Stürner 1999: 72; Gavella in Gavella, Josipović, Gliha, Belaj, Stipković, 1998: 115). ${ }^{5}$ Given the fact that the conversion of a detentor into a possessor represents deprivation of possession from the master, which becomes externally clearly detectable, for example, with the sale and delivery of movable property to a third party (in one's own name, of course), we can undoubtedly conclude that a detentor is not the person to whom the owner transferred a thing into direct possession, but the person who took direct possession arbitrarily.

$5 \S 935$ BGB provides that the acquisition of ownership under $\S 932$ to 934 is not possible if the thing was stolen from the owner, or has been lost or misplaced. The same applies if the owner was only an indirect possessor at the time when the thing was stolen from the possessor, has been lost, etc. This does not apply to money or bearer securities or to things acquired at a public auction. 
However, it would be possible to acquire ownership of movable property, obtained from a detentor, by prescription.

\section{$5 \quad$ Bodies of legal persons}

A legal person may also be a possessor. Only a legal person is thus a possessor, while its bodies or members do not have possession. However, the body that is authorised to manage the legal person exercises possession on its behalf. In a civil-law association, which is not a legal person, possession is generally exercised by all its members as joint possessors.

Our case law likewise adopted a position that members or bodies of a legal person are not possessors of things of that legal person. If the director of a limited liability company is disturbed in the use of office space of the company, the member of which he or she is, he or she has no possessory protection (Westermann, Westermann, Gursky, Eickmann, 1998: 130). ${ }^{6}$ The director of a company is not a possessor ${ }^{7}$ of the company's things, as the possessor is the company itself, while its body exercises actual control on its behalf.The body (e.g. a director) is therefore not a possessor. It may, however, as the body of the company (i.e. on its behalf) resort to all available legal remedies against third parties (Westermann, Westermann, Gursky, Eickmann, 1998: 126-127). The body of a legal person therefore has a unique position.According to theory, the body is also not a detentor of a legal person, even though its position is very similar to the latter (Honsell, Vogt, Geiser, 1998: 2204). This unique position of bodies of legal persons has its origins particularly in the fact that the bodies are not subjects of civil law.

\section{Case law}

\subsection{Holding vs. ownership}

VSL, Judgement I Cpg 146/2011, 12. 4. 2011: The difference between a non-proprietary direct possessor and a detentor lies in the fact that a detentor exercises actual control over a thing for another person and under his instructions, while a non-proprietary direct possessor exercises actual control over a thing on his or her own behalf, but recognises some higher possession of the indirect possessor.

VSL, Decision II Cp 1321/2014, 16. 7. 2014: The appellant cannot succeed by stating that the plaintiff was only a detentor, since detention (holding) is characterised by the fact that a certain person exercises actual control over a thing for another person and that such

\footnotetext{
${ }^{6}$ Report of VS RS, No. I/92, p. 24-25 - summarised after Frantar 1993, p. 317-321; see also VSM, Decision I Cp 890/2008, 12. 11. 2008; see also Schwab, Prütting, 1997, 29, 48-49.

${ }^{7}$ Possession is only exercised by a legal entity; therefore, the court rightly denied judicial protection of the legal representative (director) of a legal person (VSL, Decision I Cp 562/2013, 20. 3. 2013).
} 
exercise is based on a certain relationship between the possessor and the detentor, as well as the obligation of the detentor to act in accordance with the possessor's instructions, which was not established in the present case.

\subsection{Precarium}

VSL, Judgement and decision II Cp 489/2009, 24. 6. 2009: In view of the undisputed fact that the defendant never paid the rent for staying in the house, as the owners never even requested him to do so, this was a gratuitous use at the most. In case where the duration of use is not determined, the permission is only temporarily and may be revoked by the owner at any time (the so-called precarium under the third paragraph of Article 583 of $\mathrm{OZ})$.

VSL, Judgement and decision I Cp 2190/2012, 6. 2. 2013: As the plaintiff gave no timely statements for the termination of the contract (Article 584 of OZ), her action for the vacation of premises could only succeed if the contracting parties had not determined its purpose and duration in the contract (the so-called precarium), but the plaintiff states the opposite and refuses to return the thing (Article 583 of OZ).

VSL, Decision II Cp 3147/2012, 22. 1. 2014: Possession is not disturbed only by a person who directly causes some disturbance, but also by a person who orders or consents to such disturbance or to whose benefit the disturbance is caused, if he or she fails to distance him- or herself from such conduct (approves the conduct, considers it beneficial, and declines the restitution). Case law grants possessory protection to a holder of precarium as well.

VSK, Decision I Cp 725/2014, 13. 1. 2015: In the background of the dispute between the parties is a dispute over ownership, because the plaintiff claimed that he was using the plot in good faith, by himself and through his legal predecessors, as a proprietary possessor, while the defendants claimed that he was using the plot with the permission of the third defendant, therefore only as a detentor. A holder of precarium is not entitled to possessory protection, because the essential characteristic of (such) detentor is the awareness that he is actually exercising control for someone else. Considering the uncontested possession that has been exercised by the plaintiff for many years, the defendant has the burden of proof to demonstrate that the plaintiff has in fact exercised possession solely on the basis of the defendant's temporary renouncement of the land.

VSL, Judgement I Cp 868/2015, 20. 5. 2015: It was found that the heirs agreed that the defendant may gratuitously use and live in the house until her death. Such arrangement cannot be defined as precarium. For precarium, the use of a thing has to be relinquished gratuitously, but it is also essential that a permission until revocation is given, which did not happen in this case. 


\subsection{Possession exercised by the body}

VSM, Decision I Cp 890/2008, 12. 11. 2008: A possessor may only be a legal person or legal entity that can under positive legislation independently perform legal transaction, but not also the bodies of such legal entity. From the procedural perspective, the claim must be formed as a condemnatory claim, although this does not necessarily mean that any potential declaratory part or a separate description of the disturbance is a priori not allowed. The court based its conclusions on an incorrect substantive-law position, which states that the first and the second plaintiff no longer have the economic interest to file a action, because the defendant is no longer employed by them.

VSL, Decision I Cp 562/2013, 20. 3. 2013: Possession is only held by a legal entity; therefore, the court rightly denied judicial protection of a legal representative (director) of the legal person. 
Legal Regulation of Possession in the RePublic of Slovenia

R. Vrenčur 


\section{Proprietary and Non-Proprietary Possession}

\section{$1 \quad$ In general}

Anyone who has a thing in his possession as his own is a proprietary possessor (the first paragraph of Article 27 of SPZ). Anyone who has a thing in his possession without wishing to have it as his own and who recognises the higher legal control of an indirect possessor is a non-proprietary possessor (the second paragraph of Article 27 of SPZ).

Former regulation under ZTLR originated from lawful and bona fide possession in the definition of possessory states that bring about important legal consequences (acquisition of fruits, prescription, reparations under property law, actio Publiciana, etc.). Lawful possession was possession that was based on a valid legal title, which was necessary to obtain ownership, and that had not been acquired in a vicious manner (by force, secretly or by abuse of trust). Possession was defined as bona fide possession if the possessor did not know or could not have known that the thing in his possession was not his own (Article 72 of ZTLR). This regulation was adopted from ABGB $(\S 316, \S 326$ and $\S 345$ ABGB). ${ }^{1}$

\section{$2 \quad$ Proprietary and non-proprietary possession}

Anyone who has a thing in his or her possession as his or her own is a proprietary possessor (Eigenbesitzer). Anyone who has a thing in his or her possession without wishing to have it as his or her own and who recognises the higher legal control of an indirect possessor (a proprietary possessor or another holder, who could also be a nonproprietary possessor), is a non-proprietary possessor (Fremdbesitzer). ${ }^{2}$

\footnotetext{
${ }^{1}$ In $\S 316$, ABGB regulates just possession (rechtmäßiger Besitz), which is the same as lawful possession under the first paragraph of Article 72 of ZTLR, in $\S 326$ it regulates fair possession (redlicher Besitz), which is the same as bona fide possession under the second paragraph of Article 72 of ZTLR, and in $\S 345$ it regulates genuine possession (echter Besitz), which is the same as nonvicious possession under the first paragraph of Article 72 of ZTLR.

${ }^{2}$ German BGB defines only proprietary possession, namely in $\S 872$, in the following manner: "Wer eine Sache als ihm gehörend besitzt, ist Eigenbesitzer." A proprietary possessor is therefore a person who (regardless of whether his or her possession is based on a right) possesses a thing as his or her own. This means that a proprietary possessor exercises actual control with the will to have the thing as his or her own (animus domini). His or her awareness of other person's ownership rights is not to his detriment. A thief is therefore also a proprietary possessor. A proprietary possessor could also be, for example, a detentor who concealed the thing that was entrusted to him, etc. On the other hand, a non-proprietary possessor is a person who does not possess a thing with the will of the owner, but who possesses the thing as a holder of a restricted real or contractual right.
} 
Proprietary possession is not necessarily determined by direct physical control over a thing (Sajovic, 2000: 64). ${ }^{3}$ Thus, for example, a lessor is an indirect proprietary possessor and a lessee is a direct non-proprietary possessor. The following example is interesting as well: A rents the whole house to $\mathrm{B}$, and then he himself rents one room from $\mathrm{B}$. A is in relation to the rented room a direct non-proprietary possessor, while $\mathrm{B}$ is in relation to this room an indirect non-proprietary possessor (Baur, Baur, Stürner, 1999: 78).

If, for example, a tenant recognises the higher control of the lessor and has a thing in his possession without wishing to have it as his own, he is a non-proprietary possessor. If the tenant withholds the thing and does not return it to its owner after the expiration of the rental period, and start to exercise possession for himself (as if it was his own), he becomes a proprietary possessor. This means that the non-proprietary possessor converts into the proprietary possessor. The key element is thus the possessor's will. Therefore, a thief is also a proprietary possessor. Such relationship between a person and a thing of course does not affect the real ownership (Wolf, 1999: 76). In both examples, proprietary possessors are mala fide possessors. This means that they are not entitled to benefits that would result in, for example, the acquisition by prescription, protection under actio Publiciana, etc.

In the context of possessory states, concepts of proprietary, non-proprietary, indirect and direct possession precisely determine a possessor's position in relation to a thing, which is undoubtedly the advantage of this conceptual approach.

The distinction between proprietary and non-proprietary possession holds great importance especially in the acquisition of ownership. However, proprietary possession will not suffice on its own, as the possessor's good faith is also required. Only a bona fide proprietary possessor will be able to acquire ownership of fruits with their separation. ${ }^{4}$ The same is true for acquisition by prescription and for reparations under property law. Actio Publiciana and actio negatoria also aim to protect bona fide proprietary possession. Mere proprietary possession is sufficient only in relation to the presumption of ownership, which essentially represents the enactment of the principle of publicity in the area of movable property. This is understandable, since the presumption of ownership by itself does not result in the acquisition of ownership.

Non-proprietary possessors are, for example, a lessee, borrower, depositary, etc. A buyer who buys the thing under the retention of ownership is a non-proprietary possessor as well. Insurance provider in the fiduciary transfer of ownership is also a non-proprietary possessor (Baur, Baur, Stürner, 1999, 77).

${ }^{3}$ In this regard, the highest indirect possessor is considered a proprietary possessor (Baur, Baur, Stürner, 1999, 78).

${ }^{4}$ A usufructuary and a lessee, who are non-proprietary possessors, should also be added. This means that non-proprietary possession may also result in the acquisition of ownership, but only in relation to the acquisition of fruits. The collection of fruits constitutes the essential content of usufruct and leasing. 
The presumption of ownership is a reflection of the function of publicity in property law. In the area of immovable property, the presumption applies to the person who is recorded in the land register, while in the area of movable property, it applies to the proprietary possessor. The following provision has been included in the second paragraph of Article 11 of SPZ as a reflection of publicity in the area of movable property: "It shall be presumed that the proprietary possessor of movable property is its owner." Good faith is not relevant in this regard.

\section{$3 \quad$ Case law}

VSL, Decision II Cp 306/2011, 1. 6. 2011: Only a person who does not know and cannot know that he or she is not the owner of the thing, and is therefore justifiably mistaken in regard to this fact, can be considered a bona fide proprietary possessor. Since the defendant claimed to have concluded a rental contract for office space, he is excluded from being a bona fide proprietary possessor.

VSL, Judgement I Cp 3224/2011, 4. 4. 2012: It is true that following the adoption of SPZ, a very strict approach was adopted in terms of the assessment of good faith as the prerequisite for the acquisition of ownership of immovable property, particularly because of the increased and explicitly emphasised importance of the principle of trust in the land register. However, it became clear that this strict approach can in practice result in inadequate solutions. Consequently, it has already been renounced or mitigated by legal theory. It is also followed by the recent case law, which determines whether the error of each respective possessor is justifiable by taking into account all circumstances of the case. Possession is bona fide (or fair, according to ODZ), if a possessor does not know or cannot know that the thing in his or her possession is not his or her own. He or she has to be convinced that the thing is his or her own, even after he or she considers all circumstances with ordinary diligence. During the prescriptive period, no reasons or special circumstances may exists that could lead to a suspicion that the thing might belong to someone else, and because of which the possessor or his legal predecessor would be obligated to clarify the content of ownership relations.

VS, Decision II Ips 194/2011, 31. 5. 2012: Considering the fact that a dispute over ownership took place between the parties of the case, the second defendant cannot be considered a bona fide proprietary possessor (Cf. provision of the seventh paragraph of Article 39 of ZTLR), which is especially true given the fact that ownership of immovable property in question has been recorded in the land registry in favour of the plaintiffs' legal predecessor since 1993.

VSL Judgement I Cp 3103/2013, 29. 1. 2014: Land registration is not an unavoidable requirement for bona fide proprietary possession and both legal theory and practice permit prescription without registration. In the present case, it is crucial that the plaintiff believed that he acquired ownership of immovable property on the basis of a valid legal transaction - the sales contract. His good faith is demonstrated by the fact that he knew that the state 
recorded in the land register does not correspond to the existing state, since the first owner, who transferred ownership rights to another acquirer, was still recorded in the land register, while the plaintiff's legal predecessor failed to rectify the state recorded in the land register to match the existing state.

VS, Judgement II Ips 94/2011, 28. 8. 2014: Taking into account the presumption of good faith of a possessor under Article 28 of ZTLR, the court of second instance correctly based its negative answer to this question on the conclusion that the plaintiff has not been acting in good faith since 1976, that is, from the very beginning, because at that time he already knew the location of cadastral boundary of his land.

VS, Judgement II Ips 377/2011, 4. 9. 2014: According to the second paragraph of Article 72 of ZTLR, possession is bona fide if the possessor does not know or cannot know that the thing in his or her possession is not his or her own. Both the actual element (actual control over a thing) and the element of will (awareness of ownership of immovable property) must exist. This means that the possessor is mistaken about the person to whom the thing actually belongs. However, mere factual findings that the possessor did not know to whom the thing belongs is not sufficient, as the mistake must also be justifiable. He or she has to be convinced that the thing is his or her own, even after he or she considers all circumstances with ordinary diligence. All actions of the person acquiring ownership by prescription must be justified by the conclusion that he or she acted with due diligence or that he or she did not omit the usual due diligence.

Considering the preceding conclusions, the court in the present case agrees with the position taken by the court of appeal that a mistaken belief about the number of the plot of immovable property, i.e. on what is being transferred or donated in physical world, is not justifiable. The least that could be expected from a party acting with average diligence in transactions with immovable property is that he or she would verify whether the number of the plot of immovable property, which is being transferred or donated, corresponds to the actual immovable property in physical world. Such negligent conduct as that of the plaintiff cannot be tolerated in legal transactions (the same position was already adopted by the Supreme Court in case II Ips 608/2005 and there is no reason to abandon it now). Factual findings show that the plaintiff really did not know that he is not the owner of immovable property in question, but this is something he should have known, since, considering the specific circumstances of the case, he should have been aware that he had transferred immovable property in question in its entirety to the defendant's legal predecessor, having twice disposed of immovable property (the first time with an agreement on the inheritance, and the second time with a contract of donation). In light of this explanation, the Supreme Court concluded that by referring to the agreement on the inheritance and the contract of donation, the defendant successfully rebutted the presumption of bona fide possession (Cf. the third paragraph of Article 72 of ZTLR). 
VSK, Decision CDn 251/2015, 27. 10. 2015: It is not necessary for the owners of adjacent immovable properties to state the legal basis on which the applicant acquired proprietary possession in a statement, which proves that the requirement to issue proper land registry permission under the first indent of the first indent of the first paragraph of Article 234 of ZZK-1 was likely demonstrated. 
Legal Regulation of Possession in the RePublic of Slovenia

R. Vrenčur 


\section{Good Faith of a Possessor}

\section{$1 \quad$ In general}

A possessor is not in good faith if he or she knew or could have known that he or she was not entitled to exercise possession (Article 28 of SPZ).

SPZ provides a negative definition of good faith of a possessor. According to Article 28 of SPZ, a possessor is not in good faith if he or she knew or could have known that he or she is not entitled to exercise possession. Such entitlement of a possessor to exercise possession may refer to both proprietary as well as non-proprietary possession. Definition of good faith is therefore provided in terms of the entitlement to possess a thing. Good faith is presumed. This means that the burden of proof lies with the party who claims that the other party is acting in bad faith. Article 9 of SPZ thus explicitly provides the presumption of good faith, which is, of course, rebuttable (presumptio iuris): "Good faith is presumed, unless indicated otherwise."

German BGB (the second paragraph of $\S 932$ BGB) also contains a negative formulation of good faith. It is thus stipulated that the acquirer is not in good faith, if he or she knew, or did not know for a reason of gross negligence, that the thing does not belong to the transferor. The concept of good faith in our law is set more broadly, since good faith refers to the entitlement to possession, either proprietary or non-proprietary.

Possession in good faith (bone fidei possessio) of a things therefore occurs in two forms, either as (1) a bona fide proprietary possession or as (2) a bona fide non-proprietary possession. It is more appropriate to speak of good faith of a possessor, since his or her good or bad faith depends on his or her subjective awareness or negligent unawareness of a certain circumstance that excludes good faith of a possessor. Therefore, a bona fide proprietary possessor, when defined in positive terms, is a person who did not know or could not have known that he or she is not entitled to hold a thing in possession as his or her own. A bona fide non-proprietary possessor is a person who did not know or could not have known that he or she is not entitled to hold a thing in possession as a tenant, lessee, usufructuary, creditor in pignus, etc.

For example, person A, who bought and obtained possession of a movable thing, for which he knew or could have known that it was stolen, does not becomes a bona fide proprietary possessor. He should have known that the thing was stolen, if, for example, he bought it for a price significantly lower from the realistic market value of the thing (if, for example, A bought a used car at the car fair for half the price). In such case, A does not become the owner of the purchased thing. There is no possibility for A to become the 
owner of the thing on derivative grounds, since the seller was not an owner and was therefore unable to transfer the right, which he did not have, to A (nemo plus iuris ...). A is also not protected under Article 64 of SPZ, which regulates bona fide acquisition of ownership from a non-owner. For the sole reason that A is not acting in good faith, this manner of acquisition of ownership is not an option. For the same reason (bad faith), prescription for A's benefit is not possible (which would otherwise occur after three years of bona fide proprietary possession). ${ }^{1}$ An example of mala fide non-proprietary possession could be the following situation: person $\mathrm{B}$, who acquired direct possession of a movable thing under pignus, knew that the pledger had previously already sold this same thing to the third party with possessory agreement. If B acted in good faith, he could obtain lien on the basis of Article 156 of SPZ. ${ }^{2}$ A lessee, who leased a movable thing, which he knew to have been stolen, also does not becomes a bona fide non-proprietary possessor. For this reason, he has no right to the fruits (see the second paragraph of Article 59 of SPZ in connection with Article 96 of SPZ). A buyer of a movable thing, which he arbitrarily seized from the seller when he failed to deliver it voluntarily, thus breaching their contract, is also not considered a bona fide proprietary possessor. The buyer's possession is vicious, and can under no circumstances be considered bona fide.

\section{$2 \quad$ Special cases of acquisition}

A bona fide proprietary possessor of a movable thing is also a buyer who bought the thing from a person who did not have the right to dispose with the thing (see Article 64 of SPZ). The difference between this situation and the acquisition by prescription lies in the fact that the acquirer by prescription is harmed by the subsequent bad faith, which means that the acquirer by prescription is considered to be acting in bad faith if he or she becomes aware of the fact that excludes his good faith (mala fides superveniens nocet). For example, if he or she learns before the expiry of the prescriptive period that the thing he or she bought is stolen. Such buyer can no longer acquire ownership of the purchased movable thing by prescription. It means that he or she becomes a mala fide possessor. On the other hand, the buyer protected under Article 64 of SPZ is not harmed by the subsequent bad faith (mala fides superveniens non nocet), as long as he or she was acting in good faith at the time the thing was delivered into his possession. Such buyer does not become a mala fide possessor, since he or she already became (originally) the legal owner of the thing before that moment (at the time the thing was delivered into his possession).

1 The first paragraph of Article 43 of SPZ provides the following: "A bona fide proprietary possessor of movable property acquires the ownership thereof after three years."

${ }^{2}$ The first paragraph of Article 156 of SPZ provides the following: "A bona fide lienor acquires a lien even if the pledger did not have the right of disposal, if the pledger exercises possession of movable property by the will of its owner." This provision is actually a derivation of "a non domino" acquisition, which is regulated in Article 64 of SPZ, for the acquisition of pignus as well. 


\section{Good faith of a proprietary possessor of immovable property}

A bona fide proprietary possessor of immovable property is, for example, a buyer who took possession of immovable property on the basis of a valid sales contract, but who cannot be recorded in the land register, because the contract does not include the land register permission (registration clause). Such buyer may, depending on his qualification of possession, acquire ownership of immovable property by prescription after ten years (see the second paragraph of Article 43 of SPZ), unless he or she already received a document suitable for registration in the land register from the seller before the prescriptive period expired.

\section{Good faith of a legal person, possessory successor and co-owner}

The assessment of good faith of a legal person is based on good faith of its bodies and other persons for whom it is important, with regard to their area of work, that the thing belongs to the legal person (see Article 46 of SPZ). If possession is acquired through the representative, good faith of both the representative and the person issuing the mandate is required (Stanković, Orlić, 1989: 48).

Good faith of a possessory successor (e.g. an heir) is assessed individually. This is particularly important in case of acquisition by prescription. If co-ownership is to be acquired by prescription, good faith of each co-owner is judged independently (see Article 45 of SPZ).

\section{$5 \quad$ Case law}

VSL Judgement I Cp 3103/2013, 29.1. 2014: Land registration is not an unavoidable requirement for bona fide proprietary possession and both legal theory and practice permit prescription without registration. In the present case, it is crucial that the plaintiff believed that he acquired ownership of immovable property on the basis of a valid legal transaction - the sales contract. His good faith is demonstrated by the fact that he knew that the state recorded in the land register does not correspond to the existing state, since the first owner, who transferred ownership rights to another acquirer, was still recorded in the land register, while the plaintiff's legal predecessor failed to rectify the state recorded in the land register to match the existing state. 
Legal Regulation of Possession in the RePUblic of SLOVEnia

R. Vrenčur 


\section{Acquisition of Possession by an Heir}

\section{$1 \quad$ In general}

An heir acquires possession of the decedent's things at the moment of the decedent's death (Article 29 of SPZ).

The heirs' possession is a case of possession without actual control over a thing and without the will of the possessor (the so-called spiritualised possession) (Stojanović, PopGgeorgiev, 1980: 166). An heir acquires possession of the decedent's thing at the moment of the decedent's death (Article 29 of SPZ). This provision is important because it prevents the so-called possessory vacuum, i.e. a situation when no one is a possessor of the thing, from occurring during the time between the decedent's death and the actual acquisition of possession. The purpose of such provision, which can also be found in comparable legal systems, is to ensure possessory protection against third parties of the heir, who is at the time of the decedent's death most frequently absent. The provision is also harmonised with the provision on the acquisition of ownership by inheritance. Ownership rights are acquired by inheritance at the moment of the decedent's death as well (Article 41 of SPZ).

\section{$2 \quad$ What form of possession is inherited by the heir?}

At the moment of the decedent's death, either direct or indirect possession may be obtained. If the decedent was an indirect possessor, the same form of possession will be inherited by his heirs. If the decedent was a direct possessor, the heirs will also become direct possessors. They will thus gain direct possession without exercising direct actual control over the thing. If the decedent was a joint possessor or partial possessor, the heirs will also be limited to exercise actual control over a thing in the same manner.

If the predecessor was a bona fide proprietary possessor, such qualification of possession will generally also be acquired by the heir. For example, if the heir knew that a painting, which was purchased by his father, had been stolen, while his father was not aware and could not have been aware of this fact, the heir will become a mala fide possessor at the moment of his father's death. This is particularly important when the prescriptive period of three years in favour of the decedent has not yet expired. Similar is true for bona fide non-proprietary possession. If the predecessor was a bona fide non-proprietary possessor, the heir will generally also acquire this form of possession of the decedent's thing. Again, a situation is possible where the heir knew that the decedent exercised non-proprietary possession (e.g. under lease) of stolen movable property. 
If the decedent acted in bad faith, the successor's good faith is assessed separately (see the fourth paragraph of Article 45 of SPZ). This means that the bad faith of possessory predecessor is not inherited automatically, which is logical, since the question of bad or good faith is subjectively oriented, whereas the presumption of good faith also applies. It is possible, however, to prove that the heir was not acting in good faith either. For example, if the heir inherited a stolen painting from the decedent, and the decedent was aware of this fact, while the heir did not know and could not have known that this was the case, the heir will become a bona fide proprietary possessor at the moment of the decedent's death. In such case, the prescriptive period in favour of the heir will start to run at the moment of the decedent's death, since it could not even start to run in favour of the decedent, due to his bad faith.

According to case law, spiritualised possession exercised by the heir is weaker than actual (real) possession exercised by the possessor of the thing (estate). ${ }^{1}$

\section{Case law}

VS, Judgement II Ips 114/2008, 14. 1. 2010: the plaintiff's right to possession is based on Article 29 of SPZ and is in conflict with the defendant's rights to privacy and inviolability of dwelling. The defendant had been using the apartment in question together with the plaintiff's daughter to meet their daily needs for housing, and after her death, he was using it alone to the same extent. The plaintiff lived elsewhere. Therefore, the requested replacement of the lock or delivery of the key for the new lock would allow the plaintiff the entrance into the apartment in question and its actual use, which would in the present case represent a wrongful interference with the defendant's human rights under Article 35 and Article 36 of the Constitution of RS.

VSL, Decision I Cp 1365/2010, 1. 12. 2010: The purpose of the provisions in Article 29 of SPZ is the protection of the estate for the benefit of heirs, whereby this purpose is achieved in those cases where neither heir exercises actual control over the decedent's thing, and the estate has to be protected against interference by third parties. The plaintiff and his wife M. M. were joint possessors of immovable property in issue, until the plaintiff became an actual possessor of the whole property after his wife's death. While the defendant, who was M.M.'s co-heir, really acquired legal joint possession at the moment of her death, his possession cannot compete with a stronger, actual possession exercised by the plaintiff. Possessory protection is primarily intended to protect the existing state of actual control over a thing. For that reason, the defendant's legal joint possession cannot be equivalent to the plaintiff's actual possession.

VSL, Decision I Cp 772/2013, 9. 10. 2013: If the decedent was an indirect possessor, the same form of possession will be inherited by his heirs; if the decedent was a direct possessor, his heirs will also become direct possessors. They acquire direct possession

${ }^{1}$ See VSL, Decision I Cp 1365/2010, 1. 12. 2010. 
without exercising direct actual control over the thing. Even if the disturbance occurred while A.P. was still alive, the plaintiff as the deceased A.P.'s heir was entitled to bring an action for the disturbance of possession.

VSL, Decision II Cp 47/2014, 7. 5. 2014: The defendant cannot succeed by objecting that she is the possessor of immovable property and by referring to Article 29 of SPZ. This legal provision must be interpreted in the context of the entire institution of possessory protection, which is intended to protect actual control over things. This provision does not deny the protection of the person who exercised actual control over the thing before the decedent's death, as well as after, and does not allow the heirs to deny his or her possession in its existing scope and intensity. 
Legal Regulation of Possession in the Republic of SLOVenia

R. Vrenčur 


\section{Loss of Possession}

\section{In general}

Direct possession is lost if the possessor ceases to exercise actual control over a thing. A consequence of the loss of direct possession is the loss of indirect possession. Indirect possession is not lost if the previous direct possessor becomes the indirect possessor (Article 30 of SPZ).

A direct possessor loses possession: if he or she ceases to exercise actual control over a thing, mostly because he or she transfers actual control over a thing to another person (Baur, Baur, Stürner 1999: 69), ${ }^{1}$ or otherwise loses actual control over a thing (because of the destruction of a thing - dereliction; loss without hope that the thing will be found, etc.). Possession ceases either voluntarily (loss of possession because of the transfer to another person; dereliction) or involuntary (destruction, loss without hope that the thing will be found). Possession is not lost, however, if the possessor is temporarily unable to exercise actual control independently of his will. The chapter of SPZ on the acquisition by prescription contains a provision which states that the prescriptive period also includes the time when the possessor was temporarily unable to exercise possession for reasons independent of his will (the fifth paragraph of Article 45 of SPZ) (Flum, 1992: 750). ${ }^{2}$ Loss of possession against the will of the owner does not affect the course of the prescriptive period. This happens if, for example, a third person unlawfully seizes possession of a thing from a (bona fide proprietary) possessor, who is because of this action temporarily prevented from exercising possession, all of this as long as it takes him to regain possession of the thing (either on the basis of a permitted self-help or in the court proceedings for the disturbance of possession).

Indirect possession ceases with the loss of possession by a direct possessor (the first sentence of the second paragraph of Article 30 of SPZ); with the transfer of indirect possession on the basis of traditio longa manu (the fourth paragraph of Article 60 of SPZ); with the completion of a suspensive condition (in relation to the retention of ownership); with the return of the leased thing due to the termination of leasing relationship; with the change of a non-proprietary possessor into a proprietary possessor

\footnotetext{
${ }^{1}$ For example, if a lessee, who is a direct possessor, misappropriates movable property with or against the will of the lessor, indirect possession of the lessor ceases.

${ }^{2} \mathrm{Cf}$. the fifth paragraph of Article 45 of SPZ (previously Article 74 of ZTLR) and $\S 856$ of BGB.
} 
(Westermann, Westermann, Gursky, Eickmann, 1998: 119-120.see also Gavella 1984: $168),{ }^{3}$ etc.

The second sentence of the second paragraph of Article 30 of SPZ further stipulates that indirect possession is not lost if the previous direct possessor becomes the indirect possessor. This is a case of the formation of a multi-stage possessory relationship, where, for example, a usufructuary, who was initially a direct possessor, leases or rents a thing. While usufruct as a personal servitude is a non-transferable right, it is possible to transfer the exercise of usufruct to another person (the third paragraph of Article 230 of SPZ). A similar possessory situation occurs if a tenant sublets a thing (see Article 506 of OZ).

\section{$2 \quad$ Case law}

VSL, Decision I Cp 450/2012, 29. 8. 2012: The first paragraph of Article 30 of SPZ provides that direct possession is lost if the possessor ceases to exercise actual control over the thing. In terms of the statutory phrasing, control over a thing does not mean a permanent, everyday physical contact with the thing, but the possibility of a possessor to exercise possession if he wishes to do so. It is clear from the foregoing that when assessing whether a certain person exercises possession of a thing, which is not under his or her permanent physical control, the will of this person is the crucial factor. The plaintiff, who was exercising his joint possession by returning and using immovable property only occasionally, whereas he clearly stated during his absence that he no longer wished to use the property by ordering the other joint possessor - the first plaintiff - to empty immovable property of his things, lost his joint possession of the thing, and the first plaintiff thus became the only possessor. Circumstances in the present case were such that the plaintiff's text messages were understood as a declaration of will that the plaintiff no longer wanted to use his things (all immovable property and those movable things that he had no intention to remove), with which he was at that moment not in a physical contact, and that he therefore no longer wished to exercise actual control over those things, neither in that moment nor in the future. With such declaration of will, the plaintiff in the present case, as the court of first instance already correctly observed, voluntarily ceased to exercise his possession, as a result of which he also lost the right to possessory protection.

VSL, Decision I Cp 2684/2012, 20. 3. 2013: The concluded court settlement, with which the indirect possessor undertook to hand over the studio to the plaintiff, represents a declaration of will, with which she transferred indirect possession to the plaintiff. The person who exercised direct possession of the studio has vacated the studio and left the key in the door with the intention for the indirect possessor to claim the studio. Therefore, this is not a case of the abandonment of possession, but the intentional transfer of direct possession.

${ }^{3}$ Such is the case where a tenant (a non-proprietary possessor) buys a thing from a lessor (a proprietary possessor) under rules on delivery with the short hand (traditio brevi manu). 


\section{Self-Help as a Subsidiary Form of Possessory Protection}

\section{In general}

A possessor has the right of self-help against a person who without justification disturbs his possession or deprives him or her of it. The condition is that the danger is direct, that the self-help is immediate and urgent and that the method of self-help is appropriate to the circumstances in which the danger exists (Article 31 of SPZ).

Possessory protection has been traditionally provided in two ways. Namely, as judicial protection of possession and as self-help. The primary form of possessory protection is judicial protection of possession. Self-help should be exercised only in exceptional cases, while judicial protection of possession should remain the primary form of possessory protection. In more recent times, we can detect in comparative law the trend of restricting and even abolishing the permitted self-help, which also influenced the restriction of permitted self-help in SPZ (Tratnik, 2002: 53).

Legal theory lists two forms of self-help: (1) defensive self-help and (2) offensive selfhelp. Defensive self-help occurs when the possessor exercises self-defence of his possession, while offensive self-help occurs when the possessor retakes possession from the offender (Stojanović, Pop-Ggeorgiev, 1980: 169).

The criteria for permissibility of self-help as a form of possessory protection are determined exhaustively and must all be met simultaneously (cumulatively). ${ }^{1}$ The conditions are (1) that an unjustified disturbance of possession occurred, which at the same time requires that the person who exercises self-help is a possessor, and that the disturbance of possession is unlawful. The only exception applies to a detentor, who may exercise self-help for the possession master, even though he himself is not a possessor (the second paragraph of Article 26 of SPZ). Further conditions that must be satisfied for self-help are that (2) the danger is direct, that (3) the self-help is immediate, that (4) the self-help is urgent and that (5) the method of self-help is appropriate to the circumstances in which the danger exists.

\section{Self-help shall be immediate}

Unlike the previously applicable Article 76 of ZTLR, Article 31 of SPZ narrowed the criteria for self-help. It is therefore not enough that the danger is direct, that the self-help is necessary and that the method of self-help is appropriate to the circumstances in which

${ }^{1}$ VSL, Decision II Cp 4064/2011, 18. 1. 2012. 
the danger exists, but the self-help must also coincide with the unjustifiable disturbance of possession. SPZ thus also determined, among other criteria that were already provided by ZTRL, that the self-help shall be immediate. Self-help is a subsidiary form of possessory protection. Subsidiarity should be understood as meaning that the law does not permit an arbitrary enforcement of rights. For that reason, self-help is permitted only exceptionally, if that is provided by law. Therefore, the boundaries of permissibility of self-help should be interpreted extremely restrictively. If self-help does not comply with criteria stipulated by law, it is considered unlawful. Self-help must therefore be exercised immediately, as soon as it is objectively possible. ${ }^{2}$ Otherwise, the exercise of self-help will represent a wrongful disturbance of possession. German case law and legal theory, for example, adopted a common position that in accordance with $\S 859$ BGB, self-help should be exercised immediately or as soon as objectively possible, considering the circumstances of the case (Wolf, 1999: 72). If, for example, A unlawfully moves into B's empty apartment after it had been vacated by the tenant, in terms of self-help, B will have to react immediately and not only after a few days or weeks, considering the circumstances of the case, after he could have already taken action. If he does not act in such manner, B's disturbance of possession will become unlawful, meaning that A will be able to require possessory protection against $\mathrm{B}$, even though $\mathrm{B}$ is the owner of the apartment. In possessory proceedings, B will also not benefit from the petitory objection, claiming that he is the owner of the thing (see Article 33 of SPZ). He may, however, request the vacation of the apartment with actio rei vindicatio in special proceedings (see Article 36 of SPZ). Two procedures will therefore run at the same time. If petitory (ownership) proceedings, which took place at the same time, concludes with the force of res judicata before possessory (possession) proceedings, the judge ruling in possessory dispute will in accordance with the rule "petitorium absorbet possessorium" dismiss the claim for possessory protection (See also Frantar, 1993: 310). In possessory proceedings, only possessory objections may be invoked. Therefore, B could, if his self-help was permitted, invoke the objection of vicious possession (the second paragraph of Article 33 of SPZ) against A's possessory claim, pursuant to which the judge would have to dismiss A's claim. Other possessory objections, which will be discussed below, are of course also possible.

In line with the provision of Article 31 of SPZ is also the second paragraph of Article 33 of SPZ, which no longer allows self-help within the time limits when it is possible to request judicial protection of possession (within thirty days of the day on which the possessor learned of the disturbance and of the person who caused the disturbance and no later than one year after the disturbance occurred). Such solution was stipulated in ZTLR, which allowed self-help within the time limits that were otherwise provided for judicial protection of possession (the second paragraph of Article 78 of ZTLR). Such time gap between disturbance of possession and execution of self-help is unacceptable, because it stimulates the arbitrary exercise of rights, which is not consistent with a well-regulated legal system, where the courts are "called upon" to resolve problematic legal relations. In

${ }^{2}$ See also VSL, Decision II Cp 4064/2011, 18. 1.2012. 
the context of current regulation of self-help, the solution that was provided by ZTLR is excluded entirely.

SPZ regulates a special form of self-help in Article 83, which refers to the right to remove branches and roots. The owner of immovable property has the right to remove and appropriate branches of a neighbour's tree, which are extending into the airspace above his immovable property and roots growing into his immovable property, if they are causing disturbance, and if the owner of the neighbouring immovable property fails to do so upon his request (the first paragraph of Article 83 of SPZ) (Frantar, 1993: 120-127). ${ }^{3}$ Before he or she acts, he or she must therefore petition the owner of the tree (Illedits, Illedits-Lohr, 1999: 237). ${ }^{4}$ This of course does not apply in cases where the boundary between immovable properties lies in a forest (the third paragraph of Article 83 of SPZ). If these are protected plant species under special regulations, the affected party only has the right to compensation (see the second paragraph of Article 83 of SPZ).

\section{Case law}

VSL, Decision I Cp 4352/2009, 10. 3. 2010: The plaintiffs requested protection against disturbance of possession, because the defendants demolished a reinforced concrete retaining wall, which was constructed by the plaintiffs on the same day. The court of first instance dismissed the restitutory part of the claim, because it found it insufficiently specified and because it considered the defendant's actions a permitted self-help. The joint conduct of both original defendants was correctly identified as self-help by the court of first instance, which found that the conduct was appropriate in the circumstances, directly aimed at the restoration to the previous state of possession, and that it was an urgent and immediate reaction to disturbance of possession caused by the plaintiffs.

VSL, Decision II Cp 2330/2011, 31. 8. 2011: The aim and purpose of the institution of self-help is not to prevent the joint possessor, who excessively exercised joint possession, from exercising joint possession even to the extent which he had acquired in a permitted manner. Therefore, the action of a person who exercised self-help in a way that completely prevented the joint possessor from exercising joint possession is an excessive exercise of permitted self-help.

VSL, Decision II Cp 4064/2011, 18.1. 2012: Self-help is an exception to the rule on possessory protection, and should therefore be interpreted restrictively. The law does not prescribe any time limits after the expiration of which self-help would be considered unlawful. Self-help should be exercised as soon as this is objectively possible. Otherwise,

\footnotetext{
${ }^{3} \mathrm{Cf}$. $\$ 422 \mathrm{ABGB}$. The owner of immovable property has the right to remove branches and roots of the neighbour's tree by him- or herself, without judicial intervention. Case law also adopted the same approach.

${ }^{4}$ In fact, this is a special type of statutory (permitted) self-help.
} 
the exercise of self-help will represent a wrongful disturbance of possession. Criteria for permitted self-help must be cumulatively satisfied, which means that if one of them is not fulfilled, self-help cannot be permitted.

VSL, Decision II Cp 1321/2014, 16. 7. 2014: The defendant claimed that in June 2013, the plaintiff broke into premises in question. The defendant's conduct in August 2014 therefore cannot be considered a permitted self-help, since the stated time gap between disturbance of possession and exercise of self-help is unacceptable. By nailing wooden boards across the doors of business premises, the defendant's conduct was also not directly aimed at the restoration to the previous state of possession, when the defendant was able to freely enter into business premises, since the only effect of this action was that the plaintiff was prevented from entering into business premises in question.

VSL, Decision I Cp 1837/2014, 3. 9. 2014: The plaintiff has been using the pathway in question in the same way for several years prior to the placement of disputed obstacles on the path. Considering such findings, the assessment and evaluation is correct that the defendants' conduct was arbitrary, unlawful and did not meet the necessary requirements for permitted self-help in relation to a direct danger and time correlation between the defendants' actions and the alleged interference of the plaintiff with their possession. The appellants cannot justify their conduct with temporally remote actions and with prior events, during which the police has supposedly intervened. Self-help is an exemption from the rule on possessory protection, and should therefore be interpreted restrictively. 


\section{Dispute over Disturbance}

\section{In general}

Judicial protection against disturbance or deprivation of possession can be claimed within thirty days of the day on which the possessor learned of the disturbance and of the person causing the disturbance and no later than one year after the disturbance originated (Article 32 of SPZ).

The most significant consequence of possession is its independent protection, which is also independent from the right to a thing. In a marginal section of Article 32, SPZ regulates a dispute over disturbance of possession, whereas the term "disturbance of possession" also encompasses deprivation of possession, as provided in the text of Article 32 of SPZ.A possessor is granted judicial protection against both (mere) disturbance and deprivation of possession. Both forms of judicial protection originated from Roman law. Roman law knew two groups of interdicts intended to protect possession. Interdicta retinendae possessionis were intended for the retention of disturbed possession, while interdicta recuperandae possessionis were intended for the restitution of possession deprived vi, clam, precario. Since interdicts were a question of possession, the parties could not invoke the right to possession (Finžgar, 1952: 44-45).

\section{Legal nature of time limits for bringing an action for disturbance of possession}

It is important that judicial protection of possession, as the basic form of possessory protection, is quick. Thus, Article 425 of ZPP provides that in disputes over disturbance of possession, the court shall always have a care when fixing time limits and hearings to facilitate a speedy completion of the proceedings with respect to the circumstances of each particular case. The current reality as regards judicial protection of possession is somewhat different, since disputes for disturbance of possession are frequently quite lengthy and also professionally very demanding.

Although possession is only an actual control and not a right, it is protected by legal systems in order to prevent the arbitrary exercise of rights. This is some kind of "provisional" protection of a factual state, which does not necessarily even have anything in common with a right. Therefore, possessory protection should be quick and should, as such, protect the possessor's actual control over a thing until proven otherwise in a dispute on the basis of a right. This of course means that possessory protection may also benefit the person who does not even have the right to possession. This risk is accepted by the 
legal system, since even in such cases possessory protection prevents and sanctions arbitrary conduct (Frantar, 1993: 300).

Because of the provisional legal protection of possession, which should be achieved as quickly as possible, the time limits for the protection of possessions are short as well. These are the so-called substantive preclusive time limits, which are not extendable and do not allow the restoration to the previous state. The court rejects any action that is brought too late. Thus, in accordance with Article 32 of SPZ, judicial protection against disturbance or deprivation of possession can be claimed within thirty days of the day on which the possessor learned of the disturbance and of the person causing the disturbance and no later than one year after the disturbance occurred. The time limit of thirty days is a subjective time limit, because it is tied to subjective circumstances. This time limit begins to run on the day on which the possessor learned of both the disturbance and the person causing the disturbance. In case of repeated disturbances, the time limit begins to run on the day of the last disturbance. The one-year objective time limit begins to run on the day on which the disturbance occurred. The objective circumstance of the occurrence of disturbance is therefore considered (Frantar, 1993: 308-309).

In accordance with case law, the time limit for bringing an action for the disturbance of possession under Article 32 of SPZ is a substantive preclusive time limit. Regardless of the fact that the provision of the fourth paragraph of Article 111 of ZPP refers only to procedural preclusive time limits, this rule applies to substantive preclusive time limits as well. If the last day of the time limit falls on Saturday, Sunday, public holiday or another work-free day determined by Public Holidays Act, the time limit shall expire on the next following working day. The time limit for bringing an action, for example, cannot expire on Sunday, but on Monday. ${ }^{1}$

Case law asserted that it is only admissible to consider an amended action in a dispute over possession, if the action was amended before the expiry of preclusive time limits set out in Article 32 of SPZ. Such strict preclusive time limit are a result of the exceptional nature of an action for the disturbance of possession. The plaintiff does not exercise any of his rights with such action, but merely opposes the arbitrary conduct. However, this is only justified if it is done in an extremely short preclusive time limit. Otherwise, the interference with legal relationships would be disproportionate. Since the plaintiff amended the action after the expiry of the thirty-day subjective time limit, the court of first instance correctly held that the amended part of the action was too late. The court dismissed the claim as unfounded in its entirety, even though it should, as was correctly explained in the reasons for the decision, reject the action in its amended part on procedural grounds. ${ }^{2}$

\footnotetext{
${ }^{1}$ VSL, Decision I Cp 2348/2012, 10. 4. 2013.

${ }^{2}$ VSL, Decision I Cp 3514/2012, 22. 5. 2013.
} 


\section{Verbal disturbance of possession}

Our case law also regards verbal disturbance as disturbance of possession, but only if it poses a serious threat, as a result of which the disturbed possessor ceases to exercise possession. ${ }^{3}$ If, for example, A threatens that he will shoot his neighbour B if he stepped out of the house, as a result of which B ceases to exercise possession of his immovable property, this is a case of a legally recognised form of verbal disturbance of possession.

In case of a threat (verbal disturbance of possession), judicial protection of possession is not granted if the threat did not result in the loss or abandonment of possession and also did not cause any objective changes on the thing itself or in spatial relationship between the possessor and the thing that is subject to possessory protection. ${ }^{4}$

\section{Case law}

\subsection{Time limit for bringing an action}

VSL, Decision II Cp 3851/2010, 24. 2. 2011: In the assessment of the subjective time limit for filing an appeal, the court correctly determined that the key circumstance is the time when the defendant learned of the disturbance and not when the actual disturbance occurred.

VSL, Decision I Cp 2454/2011, 1. 2. 2012: Under Article 32 of SPZ, judicial protection against disturbance or deprivation of possession can only be claimed within thirty days of the day on which the possessor learned of the disturbance and of the person causing disturbance. This is a substantive preclusive time limit, which is not extendable, while the sanction for the failure to meet the time limit is a rejection of the action.

VSC, Decision Cp 490/2012, 8. 11. 2012: Considering the findings that the disturbing conduct occurred on2. 9. 2011, and that the plaintiff filed an action by registered mail on 30. 9. 2011, the conclusion is correct that the action was filed within the thirty-day time limit referred to in Article 32 of SPZ. Provisions stating that the time limit for bringing an action does not include the time when the application is being held at a post office also apply for the substantive time limit under Article 32 of SPZ.

VSL, Decision I Cp 2348/2012, 10. 4. 2013: A subjective thirty-day time limit, which is provided for bringing an action under Article $32 \mathrm{of} \mathrm{SPZ,} \mathrm{indeed} \mathrm{begins} \mathrm{to} \mathrm{run} \mathrm{when} \mathrm{the}$ possessor learns of the disturbance and of the person causing the disturbance, but that does not mean that the possessor may disregard the usual due diligence, which is expected of participants in relationships under property law. It is therefore crucial to determine

\footnotetext{
${ }^{3}$ Legal opinion of the plenary session of VS SRS, The report on case law of VS SRS, No. I/1970, p. 30-31.

${ }^{4}$ VSL Decision II Cp 1694/2004, 6. 10.2004.
} 
when it was possible for the possessor to learn of the disturbance and of the person causing the disturbance. As the court of first instance already correctly explained to the plaintiff, she failed to meet the stipulated time limit for bringing an action against the third defendant, so she was justifiably denied the requested possessory protection.

VSL, Judgement I Cp 1514/2013, 16. 10. 2013: According to the established position of case law, the time limit for bringing an action for the disturbance of possession under Article 32 of SPZ is a substantive preclusive time limit ${ }^{5}$, while the provision in the fourth paragraph of Article 111 of ZPP applies only to procedural preclusive time limits. ${ }^{6}$ In spite of that, the position adopted in the contested decision holds that the time limit for bringing an action had not expired on Sunday, 9. 9. 2012, but on Monday, 10. 9. 2012 and that the action was therefore filed on time and correctly.

The controversial position is based on analogous application of the third paragraph of Article 62 of OZ, according to which in the event that the last day of time limit coincides with a work-free day under the law, ${ }^{7}$ the next working day is considered the last day of time limit. The purpose of the provisions is to ensure rest on Sundays, public holiday and other work-free days, and is based on the generally established five-day working week. There are no reasons that would justify different time limits provided for the fields of law of obligations and property law. Case law adopted the same position also on the basis of previously applicable provisions of ZTLR and ZOR, which regulated contents that are comparable to the current SPZ and OZ, and which regulate the time limit for bringing an action for the disturbance of possession and time limits in the same manner. ${ }^{8}$

VSL, Decision I Cp 2238/2013, 13. 11. 2013: Correct is the conclusion of the court of first instance that in regard to the subjective time limit for bringing an action for the disturbance of possession (Article 32 of SPZ), it is not important whether the plaintiffs could have noticed a heap of sand during their everyday drive on the road, but whether they actually noticed it.

\subsection{Amendment of an action}

VSL, Decision I Cp 2481/2010, 20. 10. 2010: The plaintiff amended the action at the hearing of 20. 11.2009, thus affecting the course of substantive preclusive time limits for bringing an action for the disturbance of possession, which the court must consider ex officio. The reasons why the plaintiff decided to amend the claim, even if it was because

\footnotetext{
${ }^{5}$ See, for example, decisions VSL I Cp 4185/2009 of 17. 2. 2010, VSL I Cp 2481/2010 of 20. 10. 2010, VSL I Cp 2454/2011 of 1. 2. 2012 and VSC Cp 490/2012 of 8. 11. 2012.

${ }^{6}$ See, for example, decisions VSL I Cpg 624/2011 of 21. 6. 2011 and II Cpg 371/2011 of 20. 7. 2011.

${ }^{7}$ Since the defendants did not dispute the fact that these days include Sunday, further justification is not necessary. This position is otherwise further explained in Decision VSL I Cpg 624/2011 of 21. 6. 2011.

${ }^{8}$ VSL, Decision II Cp 457/1994, 30. 11. 1994.
} 
of the unnecessary and unlawful decision on the correction of an action, do not affect the correctness of the decision. Neither does the appellant's allegation that statements in action remained entirely unchanged, and only the motion was corrected. The amendment of a motion is still the amendment of an action. What is decisive is whether the plaintiffs claimed a different or significantly more extensive scope of the disturbance of possession with the amendment of the action. According to the assessment of the court of appeal, this applies to both, considering the fact that special features of this case should also be taken into account. Possessory protection of the entire parking lot, as requested by the plaintiffs, cannot be established to a lesser extent from the one requested before the amendment of the action, i.e. by only removing the net from certain parking spots. Therefore, it cannot be assumed that the action is not late in the part that refers to the five parking spaces, as specified by the plaintiff in the motion of 27.3.2006, since in this case the object would not be the same (previously a parking lot, now a parking spot). The decision of the first court to reject the action is therefore correct (so is the decision on the interim measure), which is why the appeal was dismissed and the decision confirmed.

VSL, Decision I Cp 3557/2010, 19. 1. 2011: With the amendment of the claim, the location of disturbance of possession has not changed, but has remained the same, i.e. the entrance to the plaintiffs' house, and the same applies to the manner of the disturbance of possession, which represents the removal and gathering of snow. These two circumstances are decisive for the conclusion that disturbance of possession indeed occurred in the present case, and they have not changed. A mere different description of the pathway, from which the defendant drove the snow to the front of the plaintiffs' house, by itself cannot be considered an amendment of action.

VSL, Decision I Cp 3514/2012, 22. 5. 2013: In a dispute over possession, it is only admissible to examine an amended action if the action was amended before the expiry of preclusive time limits set out in Article 32 of SPZ. Such strict preclusive time limit is a result of the exceptional nature of an action for the disturbance of possession. The plaintiff does not exercise any of his rights with such action, but merely opposes the arbitrary conduct. However, this is only justified if it is done in an extremely short preclusive time limit. Otherwise, the interference with legal relationships would be disproportionate. Since the plaintiff amended the action after the expiry of the thirty-day subjective time limit, the court of first instance correctly held that the amended part of the action was too late. The court dismissed the claim as unfounded in its entirety, even though it should, as was correctly explained in the reasons for the decision, reject the action in its amended part on procedural grounds.

\subsection{Recurring and continuous disturbing conduct}

VSL, Decision II Cp 2330/2011, 31. 8. 2011: Correct is the substantive-law position of the court of first instance, which found that this is a recurring disturbing conduct. In all cases, the plaintiffs argue that the recurring disturbing conduct was always the same, namely the removal of previous lock of the plaintiffs from a sliding fence gate and always 
the installation of a new lock. Every time, the plaintiffs has to establish the previous state of possession in the same repetitive way - by replacing the lock and handing over the keys of the new lock to the defendants. These are not the cases of continuous disturbing conduct, but of recurring disturbing conduct, and the time limit for bringing an action for the disturbance of possession therefore runs from each disturbing conduct separately.

VSL, Decision II Cp 913/2011, 31. 8. 2011: Based on the findings of the court of first instance that the defendant has been disturbing the plaintiff's possession of a hedge since the second half of 2009, so that he often drove a tractor into the hedge and (even then) broke its branches, whereby the plaintiff never planted any new shoots following these events, it can be concluded that disturbance of possession took place over a longer period in the same manner, and that the previous state was not established; therefore, the court of appeal agrees with the substantiated opinion of the court of first instance that the present case is a case of continuous disturbing conduct, for which the time limit for bringing an action runs from when the plaintiff became aware of the first such act and of the person who caused the disturbance.

VSL, Decision II Cp 92/2014, 2. 4. 2014: An essential criterion for assessing if disturbance of possession is a continuous conduct is whether this conduct was carried out without interruptions over a longer period, whereas the previous state was not restored during that time. ${ }^{9}$ With the contested decision, the court found that the defendant began with the alleged disturbance, i.e. changing wooden area into pasture, in June 2011 at the latest. It did not found the wooden area to be restored to the previous state during a gradual clearing of the forest in the area in question. The placement of fence pillars represents merely a change of disturbing conduct in the scope of the single activity of setting up a pasture, and not a new independent disturbing conduct.

${ }^{9}$ Cf. decisions VSL II Cp 913/2011 of 31. 8. 2011 and II Cp 4412/2010 of 18. 12. 2010. 


\section{Special Characteristics of Judicial Protection of Possession}

\section{In general}

According to Article 33 of SPZ, the court shall give judicial protection with respect to the last state of possession and any disturbance that has occurred. In this regard, the right to possession and good faith of the possessor are not taken into account. Even a possessor who obtained possession by force, secretly or by abuse of trust has the right to protection, except against the person from whom he or she gained possession in this manner if that person exercised permitted self-help as referred to in Article 31 of this act. The possessor shall not have legal protection if the disturbance or dispossession was based on a law.

Given the fact that in the context of possessory protection a bare actual control over a thing is already protected, the court may, when providing protection, consider only the last state of possession and the disturbance that has occurred. It is therefore essential for the court to determine who the last possessor of a thing was and whether the disturbance or dispossession truly occurred. In that, the court may not considered the right to possession, nor good faith of the possessor. The very concept of possessory proceedings is therefore fundamentally different from petitory proceedings. While the evaluation of the right to a thing is essential in petitory proceedings, which are based on a right, the right to possession has no relevance in possessory proceedings. This means that even a vicious possessor, ${ }^{1}$ who obtained possession by force, secretly or by abuse of trust ( $v i$, clam, precario), will enjoy possessory protection. A safeguard, provided by our law in this regard, is included in the second paragraph of Article 33 of SPZ, which stipulates that even a possessor who obtained possession by force, secretly or by abuse of trust has the right to protection, except against the person from whom he or she gained possession in this manner. This means that, for example, even a thief generally enjoys possessory protection against third parties, except against the person whose thing he or she unlawfully misappropriated. However, this provision of Article 33 of SPZ has to be applied in connection with Article 31 of SPZ, which regulates self-help. A situation where a thief demands possessory protection could only occur if the victim of theft resorted to permitted self-help under Article 31 of SPZ. Only in case of permitted self-help will the

\footnotetext{
${ }^{1}$ In the assessment of unlawfulness of the defendants' conduct as one of the elements of a tort, the court has correctly taken into account the fact that the examination of an action for the disturbance of possession shall be strictly confined to the assessment and proving of facts relating to the last state of possession and disturbance that has occurred, while the determination of the right of possession, legal grounds, good faith or unfairness of possession, or claims for damages is not permissible (Article 426 of ZPP). Possessory protection is also enjoyed by a vicious possessor; the aim of possessory protection is the prevention of arbitrary, unilateral alterations of the existing state of possession (VSL, Judgment I Cp 1420/2011, 23. 1. 2012).
} 
victim of theft invoke the objection of vicious possession (exceptio vitiosae possessionis $a b$ adversario) in possessory proceedings brought by the vicious possessor. If self-help exercised in a particular case was not permitted, the objection of vicious possession will not result in the dismissal of the claim by the vicious possessor. Such "legal absurdity" can be resolved in petitory proceedings, brought by the plaintiff against the vicious possessor.

The provision of the second paragraph of Article 78 of ZTLR was phrased somewhat differently when compared to the current second paragraph of Article 33 of SPZ. It permitted self-help and thus also the objection of vicious possession much more generously. ZTLR thus provided that a vicious possessor also has the right to the protection of possession, except against the person from whom he or she obtained possession in such manner, if the subjective time limit of 30 days or the objective time limit of one year since the disturbance occurred has not yet expired. This essentially meant that the objection of vicious possession was granted to the possessor who resorted to selfhelp because of disturbance or dispossession, and who exercised self-help within the time limits that are otherwise required for judicial protection of possession (Stojanović, PopGgeorgiev, 1980: 173). Such regulation permitted self-help too generously, which could only encourage an arbitrary conduct. For that reason, Article 31 of SPZ significantly restricted self-help by determining that self-help must, in addition to all other conditions, also be immediate. The criterion of immediacy no longer allows for the exercise of selfhelp within the time limits otherwise provided for judicial protection of possession.

Article 426 of ZPP, which is procedurally oriented, stipulates that the examination of the action for the disturbance of possession shall be strictly confined to the assessment and proving of facts relating to the last state of possession and the disturbance that occurred. Excluded is the ruling on the right of possession, legal grounds, good faith or unfairness of possession, or claims for damages. The provision of Article 426 of ZPP is in terms of its content very similar to the provision of the first paragraph of Article 33 of SPZ. In regard to substantive categories, ZPP only adds that in disputes over disturbance of possession, ruling on claims for damages is excluded as well. Possessory protection is not derived from the right to possession, but from a bare possession as the actual control over a thing. The goal of a possessory action is therefore the restoration to previous possessory (existing) state with regard to the thing. Thus, for example, the buyer, to whom the seller failed to deliver the purchased thing, even though he or she was obliged to do so, may not seize the seller's thing in arbitrary manner. In such case, the conditions for self-help are not fulfilled, because the buyer was not yet a possessor of the thing, who would protect this thing by exercising self-help. In this regard, see Article 31 of SPZ, which provides that only a "possessor" has the right to self-help. It is completely understandable that if there is no possession, possessory protection is not granted either. Judicial protection against disturbance of possession is granted to a person who proves that he or she exercised possession of the thing before the disturbance, that possession was truly disturbed, that the defendant was the one who interfered with possession, that his or her 
conduct truly represents a disturbance, and that the disturbance is unlawful. ${ }^{2}$ For example, the buyer will otherwise succeed in petitory proceedings, but will before that (generally) have to return the thing into possession of the seller who succeeded in possessory proceedings. If petitory proceedings, which are conducted at the same time, conclude with the force of res judicata before possessory (possession) proceedings, the judge ruling in the possessory dispute will in accordance with the rule "petitorium absorbet possessorium" dismiss the claim for possessory protection (Frantar 1993: 310).

An action for the disturbance of possession may also be filed against a universal legal successor of the person who unjustifiably interfered with possession. According to legal theory, it may also be filed against a singular legal successor of the person who unjustifiably interfered with possession, if the singular legal successor knew or could have known that interference with possession of his singular legal predecessor was unjustified. A detentor, however, may not be sued with a possessory action, because he or she is not a possessor but merely exercises actual control over a thing for the possession master, who has the status of a possessor (Stojanović, Pop-Ggeorgiev, 1980: 172-173).

\section{$2 \quad$ Objections in possessory proceedings}

Considering the fact that no objections that are based on the right to possession are permissible in possessory proceedings, only objections related to the existing state of possession apply. Therefore, the following objections will mainly come into consideration:

- that there was no disturbance of possession because the conduct was not a disturbing one;

- that interference with possession was not unjustified (interference with possession was justified by the law and is therefore not unlawful);

- that the plaintiff was not even a possessor of the thing, in relation to which possessory protection is being requested;

- that possession was acquired in a vicious manner (assuming that the defendant exercised permitted self-help);

- that the action was submitted too late (in this regard, see the commentary and case law on Article 32 of SPZ).

The only objection that is based on the right to possession and is permissible in possessory proceedings is associated with the rule "petitorium absorbet possessorium". If possessory and petitory proceedings were conducted at the same time and petitory proceedings ended with res iudicata effect before possessory proceedings, the defendant may object that he or she has acquired the right to possession, which is a reason for the court has to dismiss the claim of the possessory action. This rule is not explicitly provided under SPZ. Article 36 of SPZ only provides that regardless of a dispute over disturbance of possession, judicial protection of possession may be claimed on the basis of the right to possession.

${ }^{2}$ VSL, Decision II Cp 3425/2009, 13. 1. 2010. 
However, this rule is fully supported by legal theory (Frantar, 1993: 309; Stojanović, PopGgeorgiev, 1980: 173) and case law. In one of the cases, the court ruled the following: "When the border was determined, the right to possession of the disputed area along the border between lands was determines as well; this decision became final during the course of the present proceedings. It is worth emphasising that the purpose of possessory protection is a temporary and provisional regulation, which lasts until someone proves in civil procedure that they have the right to possession (the rule petitorium absorbet possessorium). During the course of litigation, the plaintiff therefore also acquired the absolute protection of the disputed part of immovable property and not only provisional possessory protection."

\section{Unlawfulness of disturbance of possession}

Disturbance of possession must be unlawful. ${ }^{4}$ Therefore, a possessor has no legal protection if disturbance or dispossession was based on a law (the third paragraph of Article 33 of SPZ). The cited provision particularly wishes to emphasise that only the law may exclude unlawfulness of the interference with possession. This means that the unlawfulness of the interference with possession cannot be excluded, for example, with a legal transaction. For example, in practice it often happened that a lessor, a seller with the retention of ownership, etc., determines in the legal transaction that in the event of the failure of the opposing party to fulfil their obligations, he or she is entitled to collect the thing delivered. Since such contractual clauses would excessively stimulate arbitrary conduct, SPZ determined that the exclusion of unlawfulness of the interference with possession shall be based on the law. Thus, for example, the interference with possession is not unlawful, if it is caused by an enforcement agent who is exercising his powers delegated by ZIZ and by a judgement issues in a particular case on the basis thereof.

Case law explained unlawfulness as a prerequisite for disturbance of possession in the following manner: "The statutory determined phrase based on the law really should not be interpreted so narrowly that a reason for the disturbance should be explicitly stated in the law. Case law established a clear position that SPZ denies judicial protection only in cases when interference with possession is based on the law, and that according to the third paragraph of Article 33 of SPZ, only those persons who are permitted to interfere with possession under a special act are safe from the accusation that they caused the disturbance. Case law also already explained that disturbance of possession can be caused only by such actions and conduct that are contrary to positive regulations, legal order, or by actions and conduct for which a legal subject has no authorisation granted on proper legal grounds; whereas legal theory already adopted a position that a legal transaction, even when established in accordance with the valid legal order, can never exclude unlawfulness, while case law adopted a position that unlawfulness may be excluded if the conduct is based on a decree (or another executive act) issued on the basis of the law. In

\footnotetext{
${ }^{3}$ VSL, Decision I Cp 621/2011, 22. 6. 2011.

${ }^{4}$ VSL, Decision II Cp 3425/2009, 13. 1. 2010; VSL, Decision I Cp 377/2010, 31. 3. 2010.
} 
other words: unlawfulness of disturbance is excluded when this is explicitly stated by the law, or when the action (conduct) is carried out on the basis of the executive act, provided that the latter was adopted on legal basis or that the law conferred to this executive act the authority to regulate legal relationships (in greater details)."

German BGB is very consistent in this regard, because it uses a term "verboten Eigenmacht" (see $\S 858,859,861,862$, etc.), with which it explicitly refers to the notion of prohibition or unlawfulness in relation to actions that result in disturbance of possession or dispossession. The term "verboten Eigenmacht" as a prohibited arbitrary interference with possession against the possessor's will is especially determined under $\S$ 858 BGB.

\section{$4 \quad$ Protection of direct and indirect possession}

An indirect possessor is also entitled to possessory protection against a third party who disturbs a direct possessor's possession or deprives him or her of it against his will (Westermann, Westermann, Gursky, Eickmann, 1998: 152). ${ }^{5}$ In the context of our legislation, such conclusion can already be reached on the basis of Articles 31 and 32 of SPZ, since each possessor, regardless of the type and qualification of possession, is guaranteed possessory protection (Krisper-Kramberger, 1985: 148). In case of disturbance or dispossession caused at the will of a direct possessor (a direct possessor subleases the property in violation of the contract or without proper authorisation transfers the property to a third party), the indirect possessor has no possessory protection (Schwab, Prütting, 1997: p. 43). ${ }^{6}$ The direct possessor's will is therefore essential for the question of whether the disturbance of possession was unlawful (Westermann, Westermann, Gursky, Eickmann, 1998: 135).

Furthermore, a direct possessor may also request possessory protection with the claim against the indirect possessor. German theory and case law grant him or her the right to self-help as well (Schwab, Prütting, 1997: 44; Westermann, Westermann, Gursky, Eickmann, 1998: 151). ${ }^{7}$ The same applies for our regulation. Our theory and case law grant possessory protection against the direct possessor to the indirect possessor (Frantar

\footnotetext{
${ }^{5}$ In case of dispossession, the indirect possessor is entitled to require the restoration to the previous state of possession (for the benefit of the direct possessor); if the direct possessor cannot or does not wish to retake possession, the indirect possessor may require the possession to be returned to him or her directly (translation of $\S 869$ BGB).

${ }^{6}$ A third party does not interfere with direct possession unlawfully (Krisper-Kramberger, 1985: 148).Therefore, an indirect possessor will be able to protect his or her interests only with a petitory claim, which is based on a right.

${ }^{7}$ Possessory protection of a direct possessor lasts for the entire duration of the legal relationship that is the basis for such state of possession. For example, if a tenant exercises possession of a thing even after the expiry of the lease and does not want to return it into the lessor's direct possession, he becomes the so-called vicious possessor and is not entitled to possessory protection against possible and timely self-help exercised by the lessor.
} 
1993: 304, 342 and the following). On the other hand, German theory and case law reject such possibility. An indirect possessor therefore has no possessory claim, nor self-help, in relation to a direct possessor, but he or she does have a claim based on the right (either a contractual or real right) to possession (Schwab, Prütting, 1997: 43, 54; Westermann, Westermann, Gursky, Eickmann, 1998: 151).

Likewise, according to some of our theoreticians, an indirect possessor should also be recognised the right to self-help against a third party, but only if a direct possessor, who is absent, was disturbed or deprived of his possession as a result of unlawful conduct (Stojanović, Pop-Ggeorgiev, 1980: 170). ${ }^{8}$

Worth noting are positions adopted by German theory and case law, which in the abovementioned cases deny possessory protection of an indirect possessor against a direct possessor, since the justification of his claims falls within the content of legal relationship, making their legal nature petitory; therefore, such situations should be resolved in petitory proceedings, i.e. proceedings based on a right. In possessory disputes, the court does not examine a right. Protection of indirect possession undermines the fundamental purpose of the protection of possession. An indirect possessor should enjoy possessory protection only when (which is, according to German theory, only possible by bringing an action, not in the form of self-help) a third party unlawfully disturbs or deprives a direct possessor of his possession. Finžgar also states that possessory protection of an indirect possessor against a direct possessor is not an option, because the relationship between the direct and indirect possessor is not an external state of possession, but can only be a legal relationship (Finžgar 1985: 401-402).

\section{The intensity of disturbance of possession and economic interests of the plaintiff}

Not all interference with possession represents interference that would justify judicial protection. This is (can be) only such conduct that significantly hinders the possessor in the exercise of his possession. The interference with possession must be such that it either prevents or significantly hinders the exercise of possession. Therefore, the conduct that otherwise interferes with, but does not significantly affect the previous manner of exercising possession is not considered legally relevant. Each (insignificant) change of the existing state does not yet represent disturbance or dispossession in the legal sense (Article 32 of SPZ). ${ }^{9}$ The intensity of disturbance of possession must be such that the possessor is partly deprived of possession or is disturbed in a quiet enjoyment of possession. In case of a single disturbing action, the action must be such that it decisively interferes with the possessor's quiet enjoyment of possession. In the opinion of the court of first instance, parking a car on foreign immovable property because of a phone

\footnotetext{
${ }^{8}$ German theory fully rejects such possibility (Schwab, Prütting, 1997: 43).

${ }^{9}$ Cf. VS, Decision II Ips 669/2007, 1. 10. 2009.
} 
conversation and looking through a journal do not represent the situation in which legal protection under provisions of Articles 33 and 34 of SPZ would be justified. ${ }^{10}$

Possessory protection is essentially the protection of economic interests of a party, rather than his or her legal interest. A category of economic interest as a prerequisite for possessory protection was established by case law. If there is no economic interest or if economic interest is minimal, the request for possessory protection is not justified. ${ }^{11} \mathrm{~A}$ disturbing interference is any wrongful interference which prevents or significantly hinders the exercise of possessory entitlement. Not every change of the existing state constitutes a disturbance. In order to be considered a disturbance, the change of the existing state must have economic and practical implications. ${ }^{12}$ An action has to represent a relevant interference with possessory state of the plaintiff in order to be identified as disturbance of possession. The removal of garden furniture from a part of the land, which only occurred twice, although according to the plaintiff by violent means, can be described only as a negligible change of possessory state, which has neither legal nor economic significance. ${ }^{13}$ A disturbing conduct is a legal standard, the meaning of which has to be determined in each particular case. In this respect, it is necessary to consider all circumstances of the case and ensure that claims for possessory protection are not abused. Case law has repeatedly stressed that when deciding on justification of the request for judicial protection on the grounds of disturbance of possession, economic interest of the possessor has to be taken into account. In such proceedings, the evaluation of the latter has the function of a test of whether the plaintiff as a possessor abused any rights, granted by law, by bringing an action. Not every insignificant change of the existing state represents disturbance of possession. The conduct is considered disturbing only in case of a legally relevant interference with possession. The absence of a direct economic interest may thus render the plaintiffs' legal interest for possessory protection questionable. $^{14}$

\section{The claim}

The plaintiff has no legal interest for a declaratory part of the claim in proceedings for disturbance of possession. It is true that the established case law is different, because it allows the plaintiffs to also invoke declaratory parts of the claim in such proceedings, ${ }^{15}$

\footnotetext{
${ }^{10}$ VSL, Decision II Cp 2831/2013, 15. 1. 2014.

11 VSL, Decision I Cp 495/2010, 19. 5. 2010.

${ }^{12}$ VSL, Decision I Cp 4722/2010, 6. 1. 2011.

13 VSL, Decision I Cp 3598/2010, 19. 1. 2011.

14 VSL, Decision I Cp 2695/2011, 22. 2. 2012.

${ }^{15}$ In the case of actions for the disturbance of possession, it is also important that declaratory claims are always connected to the condemnatory part and that the declaratory part therefore explains the condemnatory part. The claim should thus be considered uniformly, whilst the dismissal of the declaratory part would generally result in the vagueness of condemnatory part. Therefore, case law still permits the declaratory part of the claim in proceedings over disturbance of possession, and
} 
but never as separate claims, only in connection with condemnatory claims; claims for restitution or prohibition. ${ }^{16}$ The plaintiffs thus generally invoke declaratory claims (in addition to condemnatory) in disputes over disturbance of possession. Regardless of this fact, the procedural nature of the claim is still condemnatory. Before deciding on the claim, the court has to determine whether dispossession or disturbance of possession has occurred, but these factual findings belong in the reasoning and not in the operative part of the judgement. In one of the decisions, the court correctly stated: "In disputes over disturbance, case law permits such claims and operative parts of decisions as the claim raised by the plaintiff, so that the disturbance which has occurred is established first, followed by the prohibition of actions that are described in a declaratory part of the action. Recent case law has adopted a theoretically more correct position and has been rejecting declaratory parts of actions, because a declaratory action may be filed only under conditions laid down in Article 181 of ZPP (especially because this requires the finding of facts - the disturbance that has occurred). This was done by the court of first instance as well. In doing so, the court failed to recognise that the second point of the operative part of the decision, in which the court upheld the claim and prohibited the defendant from interfering with the plaintiff's possession with these and similar actions in the future, remained unspecified. Taking this approach, in the second point of the operative part the court should have precisely determined the actions, which the defendant is prohibited from performing, using a description from the declaratory part of the action. The appeal rightly states that it is not actually clear what the court prohibited the defendant from doing. That could also be understood as meaning that the defendant is prohibited from carrying out all actions, which was not requested by the applicant. With that, the operative part of the decision became unspecified and incomprehensible, which constitutes an absolute severe violation of civil procedure provisions under point 14 of the second paragraph of Article 339 of ZPP."17

"Recent case law has been rejecting declaratory parts of actions for disturbance, since they may be filed only under conditions laid down in Article 181 of ZPP. The court's conclusion that the condemnatory and prohibitory part of the claim would remain unspecified upon the rejection of the declaratory part of the action is not correct. In fact, it includes a fully specified obligation of the defendant (a description of the defendant's conduct, with a precise geometrical definition of a part of the pathway where the restoration to the previous state is being sought), and the claim therefore requires no further legal reasoning. Even if this was the case, the court would be required to specifically re-form the condemnatory and prohibitory part of the claim using the declaratory part." 18

there is no rational reason for the court of appeal to dismiss the action in its declaratory part (VSL, Decision II Cp 4912/2010, 25. 5. 2011).

16 VSL, Decision I Cp 22/2010, 8. 4. 2010.

17 VSL, Decision I Cp 44/2011, 5. 5. 2011.

18 VSL, Decision I Cp 603/2011, 3. 8. 2011. 


\subsection{In general on the protection of possession}

VSL, Decision II Cp 3425/2009, 13. 1. 2010: Judicial protection against disturbance of possession is granted to a person who proves that he or she exercised possession of the thing before the disturbance occurred, that possession was truly disturbed, that the defendant was the one who interfered with possession, that his or her conduct truly represents disturbance, and that the disturbance is unlawful. The possessor has the right to exercise self-help against the person who unjustifiably disturbs or deprives him or her of possession, while the court grants legal protection with respect to the last state of possession and any disturbance that has occurred. In this regard, the right to possession and the possessor's good faith are not taken into account. Possessory protection is also granted to a person who obtained possession by force, secretly or by abuse of trust, except against the person from whom he gained possession in this manner, if that person exercised permitted self-help (part III of SPZ).

VSL, Decision I Cp 377/2010, 31. 3. 2010: Legal grounds for ruling in the present case are found in the provision of Article 33 of SPZ, according to which the court shall give judicial protection with respect to the last state of the possession and any disturbance that has occurred, while in this regard the right to possession and good faith of the possessor are not taken into account. According to Article 426 of ZPP, the examination of an action for the disturbance of possession shall be strictly confined to the assessment and proving of facts relating to the last state of possession and the disturbance that occurred. In a dispute over possession, judicial protection is granted to a person who proves that he or she was a possessor of the thing before the disturbance, that possession was truly disturbed, that the defendant was the one who disturbed possession, that his or her allegedly disturbing action truly constitutes a disturbance and that his or her action is arbitrary and unlawful. The main purpose of such protection is therefore not the protection of rights, but the prevention of arbitrary interference with another person's possession, even if only temporarily.

VSL, Decision II Cp 36/2009, 7. 4. 2010: Since in disputes over disturbance of possession the last state of possession before the disturbance is always determined in accordance with Article 33 of SPZ, and the examination of an action is confined to the assessment and proving of facts relating to the last state of possession and the disturbance that occurred, while objections referring to the right of possession are excluded under Article 426 of ZPP, it is consequently legally irrelevant that an operator in the construction of highways otherwise had the right to possession, even if he did not actually realise this right .In the present dispute, it was therefore necessary to determine whether possession of the disputed part of the land was exercised by the plaintiff, or perhaps by DARS or its operators, before the disturbance. 
VSL, Decision I Cp 621/2011, 22. 6. 2011: When the border was determined, the right to possession of the disputed area along the border between lands was determines as well; this decision became final during the course of the present proceedings. It is worth emphasising that the purpose of possessory protection is a temporary and provisional regulation, which lasts until someone proves in litigation that they have the right to possession (the rule petitorium absorbet possessorium). During the course of litigation, the plaintiff therefore also acquired the absolute protection of the disputed part of immovable property and not only provisional possessory protection.

VSL, Judgement I Cp 1420/2011, 23. 1. 2012: In the assessment of unlawfulness of the defendants' conduct as one of the elements of a tort, the court has correctly taken into account the fact that the examination of an action for the disturbance of possession shall be strictly confined to the assessment and proving of facts relating to the last state of possession and disturbance that has occurred, while the determination of the right of possession, legal grounds, good faith or unfairness of possession, or claims for damages is not permissible (Article 426 of ZPP). Possessory protection is also enjoyed by a vicious possessor; the aim of possessory protection is the prevention of arbitrary, unilateral alterations of the existing state of possession. Unlawful interference with possession does not necessarily also constitute the unlawful conduct in terms of tort law. Unlawfulness in terms of possessory protection means that only the law may exclude unlawfulness of interference with possession. Unlawful action as a prerequisite of tort liability of the person who caused the damage is a conduct that exceeds the boundaries of the freedom of actions, which are determined by an unavoidable mutual co-dependence of persons, their statuses and goods.

VSL, Decision II Cp 2875/2011, 15. 2. 2012: Possession and possessory protection are not dependent on the question of whether the plaintiff has been using the apartment regularly or only occasionally, or whether he had a larger or a smaller number of his things stored in the apartment. For possession, it is not necessary that a permanent physical contact exists between the possessor and the thing. Essential is the answer to the question of whether the possessor has a possibility to, whenever he wants, always use and enjoy the thing. This is a question of accessibility, which is one of the criteria (in addition to external visibility, permanence and exclusivity) for the existence of possession and the consequent possessory protection.

VSK, Decision Cp 126/2012, 6. 3. 2012: It is essential that immovable property in question is the subject of the estate, and because the plaintiffs belong to the circle of legal heirs of the decedent, they acquired joint possession of the decedent's things as the moment of his death (Article 29 of SPZ), which is why they are entitled to possessory protection.

VSL, Decision II Cp 966/2012, 5. 9. 2012: The plaintiff is entitled to possessory protection regardless of whether the defendant tried to prevent possession of immovable property in question by replacing the lock. It is essential that the plaintiff kept using immovable property even after the first replacement of the lock on 26. 11. 2010 and had 
exclusive possession thereof. In a dispute over disturbance of possession, it is not the quiet enjoyment of possession that is decisive, as was mistakenly claimed by the appeal, but rather possession which the plaintiff managed to retain each time with the exercise of the permitted self-help, therefore, by blocking the changed lock and using immovable property in question, into which the plaintiff had been entering through the balcony doors or windows after the lock was blocked.

VSL, Decision I Cp 1246/2012, 17. 10. 2012: The appellant based his appeal on assertions that the defendants were never entitled to exercise possession of the apartment, because they never fully paid the purchase price. The undisputed fact that the defendants did not fully pay the purchase price cannot be decisive in the present case. As previously stated, the possessor's good faith is completely irrelevant in disputes over disturbance, and so is the right to possession. It is only important who had the last possession of the apartment, regardless of how he or she acquired possession. For that reason, the court of first instance did not need to more thoroughly consider and take a position on the fact that the apartment had not been formally handed over to the defendant because of the non-payment of the purchase price.

VSL, Decision II Cp 1514/2012, 19. 12. 2012: Unlawful immissions constitute the disturbance of possession as well, which is why the possessor may also invoke possessory protection because of the excessive noise or other immissions.

VSL, Decision I Cp 562/2013, 20. 3. 2013: Possession is only held by a legal entity; therefore, the court rightly denied judicial protection of a legal representative (director) of the legal person.

VSL, Decision I Cp 474/2013, 17. 7. 2013: The assessment of the disputed claim from the perspective of substantive law is regulated by the provisions of SPZ on disturbance of possession (Article 32 and the following). A legally relevant fact, which is especially disputed by the parties, is whether the conduct of the defendant was unlawful and the plaintiff has no legal protection (the third paragraph of Article 33 of SPZ). The appellate court concluded that only the law can exclude unlawfulness of the interference with possession. This also means that when assessing unlawfulness of the defendant's conduct, the court must evaluate his legally based right and the right of the plaintiff.

VSL, Decision II Cp 3147/2012, 22. 1. 2014: Possession is not disturbed only by a person who directly causes some disturbance, but also by a person who orders or consents to such disturbance or to whose benefit the disturbance is caused, if he fails to distance himself from such conduct (approves the conduct, considers it beneficial, declines restitution).

VSL, Decision I Cp 3054/2013, 5. 2. 2014: The plumbing in question also became a part of lands, on which it was installed, with the construction and instalment thereof. In spite of this fact, the defendant's assertion that the plaintiffs could have claimed judicial 
protection of possession only of the land as a whole is unjustified. The principle of speciality in property law (Article 7 of SPZ) does not apply to possessory states. Even though a part of a thing cannot be subject to ownership or other property rights, because it is not an independent thing, it can be subject to partial possession. The plaintiffs can therefore invoke possessory protection also (only) for the plumbing and water supply. It is true that water is a natural resource in general use, but this does not exclude unlawfulness of the defendant's interference. As demonstrated by the evidence-taking procedure of the court of first instance, the defendant gained access to the water by arbitrarily connecting to the plaintiff's plumbing and water supply. In any case, the plaintiffs are not accusing him of disturbance of possession of water, but of disturbance of possession of their plumbing. The fact that the state has not externally changed is irrelevant in this regard. There is no doubt that the plumbing has since been more heavily used and that the defendant's additional connection has changed the previous manner of exercising possession, because the plumbing together with the connector no longer serves only the plaintiffs, but the defendant as well, which is why the appellate court considers it a disturbance as well.

VSK, Decision I Cp 89/2014, 10. 6. 2014: The defendant's objection that he had been verbally prohibiting the plaintiff and her family from using his land for the access to the plaintiff's plot since 2006 was dismissed by the court of the first instance with a legitimate argument that in spite of all that, the plaintiff has been using the road until February 2013. She is therefore entitled to possessory protection.

VSL, Decision I Cp 3476/2013, 17. 9. 2014: Based on the findings of the first court and documents in the file, it can be inferred, among other things, that the cohabitation of the parties was already dissolved several years before 19. 4. 2012, that the plaintiff has actually not been living in the house on the street K. for many years, because he was staying elsewhere, that his occasional short-term visits to the house regularly resulted in the plaintiff's physical attacks on the defendant and the sons, and that the plaintiff was causing damage to property during his visits to the house by destroying things and rooms therein. Under such circumstances, the plaintiff could not have been considered a joint possessor of the house, who would be entitled to possessory protection, even before September 2011. Possession is direct actual control over a thing, and the content of such possession is mainly the entitlement of a possessor to use or enjoy a thing in accordance with its intended purpose. The use of a thing must be such that it brings the possessor certain benefits. Only such possession can be subject to possessory protection.

VSK, Decision I Cp 725/2014, 13. 1. 2015: Both in the court of first instance and in the appeal, the defendant recognised the plaintiff's long-term use of the plot, which is the subject to this dispute over disturbance of possession (the plaintiff claimed in the proceeding that his father enjoyed and used immovable property between 1975 and 1999 , while he has been enjoying and using it himself since 1999). The appeal also acknowledged that a dispute over ownership is actually behind this dispute between the parties, because the plaintiff claimed that he was using the plot himself and through his 
legal predecessors in good faith as a proprietary possessor, while the defendants claimed that he was using the plot with the permission of the third defendant, therefore only as a detentor. Since under Article 33 of SPZ the court grants judicial protection in disputes over disturbance with respect to the last state of possession and with regard to disturbance that has occurred, while the right to possession and good faith of the possessor are not taken into account, the question of who is really the owner of the land is not essential for the decision in the present case. The appeal completely unjustifiably refers to the case I Cp 474/2013, since the actual state of the case is not comparable to the present one, which is why the appeal unjustifiably requires the weighing of the defendant's ownership of the disputed plot and entitlements deriving from this right against the plaintiff's right to exercise possession of immovable property even after the prohibition was imposed by the defendant.

VSK, Decision I Cp 741/2014, 13. 1. 2015: While it is true that the plaintiffs claimed in the action that they are accessing their plots (No. 1540/1,1547/1 and 1538/0 c.c. T) via the established "servitude pathway", which leads across the defendant's plot, it is possible to conclude clearly enough on the basis of their statements that these statements refer to the use of the pathway that partly leads across the defendant's plot, which means that the plaintiffs actually claimed that they exercised control over a part of the defendant's immovable property. The court has therefore quite correctly addressed the question of whether the plaintiffs were possessors of the pathway in question and whether their possession was really disturbed. Incorrect are appellate allegations that the court ruled on matters not covered by statements of the action. SPZ truly no longer recognises the concept of possession of a real servitude (as opposed to the third paragraph of Article 70 of ZTLR), but the protection of possessory state of a holder of servitude has not changed in terms of its content. ${ }^{19}$

\subsection{Intensity of disturbance of possession and economic interests of the plaintiff}

VS, Decisison II Ips 669/2007, 1. 10. 2009: Not all interference with real servitude represents interference that would justify judicial protection. This is (can be) only the conduct that significantly hinders the holder of servitude in the exercise of his restricted real right; the interference must be such that it either prevents or significantly hinders the exercise of the content of servitude. Therefore, the conduct that otherwise interferes with, but does not significantly affect, the previous manner of exercising servitude is not considered legally relevant; each (insignificant) change of the actual state does not represent a disturbance or dispossession in the legal sense (Article 32 of SPZ). The disputed exercise of the defendant's ownership entitlements on the servient land (which has its basis in the provisions of the first paragraph of Article 37 and Article 12 of SPZ) - i.e. the installation of a wooden fence (with removable door) on the servitude pathway [It was concluded finally that the defendant installed the disputed fence in order to prevent his sheep from grazing on the plaintiff's property] - does not constitute such a hindrance

${ }^{19}$ See also Decision VSL I Cp 3297/2012. 
for the plaintiff (the holder of servitude) that he would be entitled to possessory protection. Considering the established irrefutable factual basis for the final decision, according to which the gate in the fence in question are light and can be removed quickly and easily, the assessment of the courts of lower instance that the fence does not represent a significant obstacle to the exercise of the plaintiff's joint possession is correct.

VS, Decision II Ips 568/2008, 27. 1. 2011: A disturbing action is an action carried out by a person who is causing disturbance over a thing in foreign possession, with which a new, altered state of possession is established; a disturbing action consists of two complementary effects on the subject of possession: actual possession of the previous possessor ceases or is restricted, while actual control of a person who is causing the disturbance is simultaneously newly established, or his or her previously existing actual control is expanded or freed of its previous restrictions. The appellate court's opinion that the plaintiff was disturbed in his possession of a part of a residential building (just) because he left for a few minutes, because of the defendant's outburst, and could not quietly consume a meal, because the defendant threw it into the sink, is incorrect from the perspective of substantive law.

VSL, Decision II Cp 4524/2009, 14. 1. 2010: A prerequisite of judicial protection against disturbance of possession is not economic interest, but legal interest. If there is no legal interest, the existence of economic interest does not suffice, unless both interests are overlapping in terms of their contents. However, if economic interest is demonstrated, this does not necessarily mean that legal interest for an action for the disturbance of possession is demonstrated as well. Thus, when the defendant installed a barrier at the entrance of the industrial complex and set up a security service or a security guard, who keeps a record of visitors and raises a barrier for persons who can prove that they are entitled to enter the area, he did not significantly interfere with the existing manner of the plaintiff's exercise of joint possession (see the provision of Article 35 of SPZ) and did not act unlawfully, since the plaintiff was not significantly hindered as regards the access to his facilities.

VSL, Decision I Cp 374/2010, 8. 4. 2010: The conduct of the defendant, who built a protective fence on a part of the plot on the basis of a building permit, whereas the plaintiff did not claim that the enclosed part of the plot was too big or that the fence was unnecessary, does not constitute a disturbing conduct.

VSL, Decision I Cp 495/2010, 19. 5. 2010: Possession is actual, i.e. physical and economic, control over a thing; a possessor of a thing is a person who is in such relationship with a thing that he uses, enjoys and disposes with the thing, regardless of the right to do so. It is essential that a possessor, whenever he wants to do so, always has an option to use, enjoy and dispose with the thing. Since May 2008, however, the plaintiffs no longer had access to the part of the land which represented the only possible way to reach the part of the hedge which was trimmed by the defendant on May 2009. Therefore, they had no actual control over that part of the hedge. The court considers only 
the last state of possession (Article 33 of SPZ), i.e. actual control over a thing. The fact is that the plaintiffs had no access to the disputed part of the hedge. The reason for that is not decisive in a dispute over disturbance of possession. A hedge is indivisible by its nature, which is why it is possible to exercise possession of only a part of the hedge.

Possessory protection is essentially the protection of economic interest of a party, rather than his or her legal interest. If there is no economic interest or if economic interest is negligible, the request for possessory protection is not justified. The plaintiffs, however, exercise actual control over the remaining part of the hedge, which they maintain and use in an undisturbed manner as a natural separation from their neighbours. Therefore, the hedge retained its function. This is another reason why the claim for possessory protection is not justified.

VSL, Decision I Cp 4722/2010, 6. 1. 2011: A disturbing interference is any wrongful interference which prevents or significantly hinders the exercise of possessory entitlement. Not every change of existing state constitutes disturbance. In order to be recognised as disturbance, the change of existing state must have economic and practical importance.

VSL, Decision I Cp 3598/2010, 19. 1. 2011: An action is identified as disturbance if it represents a relevant interference with the plaintiff's possessory state. The removal of garden furniture from a part of the plot, which occurred only twice, although according to the plaintiff by violent means, can be described only as a negligible change of possessory state, which has neither legal nor economic significance.

VSL, Decision I Cp 401/2011, 31. 8. 2011: (...) that disturbance of possession occurs only in case of a certain action or conduct which directly interferes with actual control of a person over a thing, or of a statement which deters a possessor from the use of a thing. The defendant's statement, by which he prohibited the plaintiff from exercising the right, of which he also informed S. d.o.o, does not directly interfere with his direct actual control over a thing, while the statement also contains no serious threats that could cause the plaintiff to feel threatened in the exercise of his possession. Furthermore, the defendant resorted to the action, granted by law to the owner, to either terminate eventual contractual relationship with a statement or to request the interference with his ownership to cease. Since the plaintiff failed to prove the disturbance or deprivation of possession, as well as unlawfulness of the action, the court of first instance correctly dismissed the claim.

VSL, Decision I Cp 1294/2011, 19. 10. 2011: (...) the defendant was not walking on the plaintiffs' immovable property. At the most, he stepped across the boundary after the dispute occurred, and stayed there for a short period of time. The appellate court agrees with the opinion from the contested decision that economic interest for the protection of the plaintiffs' possession is so negligible considering the specific circumstances of the case, that the claim in question does not represent such manner of exercising the right to possessory protection that would justify its purpose (Cf. legal opinion of the plenary session of VSS of 24. and 25. 6. 1986). If the claim was upheld, this would represent an abuse of the institution of judicial protection of possession. Other defendant's interfering 
actions across the boundary cannot be considered in the assessment of economic interest in the present case either, since with the action the plaintiff sought only the protection of two disturbing actions, which were examined by the court, and consideration of other interfering actions would result in ruling outside the scope of the claim for protection.

VSL, Decision I Cp 2857/2011, 15. 2. 2012: [The court of first instance] found that the plaintiff failed to prove the defendant's actions (pruning and trimming stems of the hedge and cutting grass and undergrowth south of the hedge), which are supposed to constitute disturbance of possession of the hedge on his plot No. 617 c. c. x., and that such negligible alterations of the existing state, with no visible damage, do not justify possessory protection. Therefore, the court did not assess the last state of possession.

When on 14. 6. 2010 the defendant allegedly pruned and trimmed stems of the hedge and cut the grass and undergrowth south of the hedge with a scythe, the plaintiff could have been only slightly hindered in the exercise of possession of the hedge. The shaping of the hedge in one's own taste and the use of cut grass in the present case certainly do not demonstrate economic and therefore legal interest, and the same applies for the notice, emphasised in the appeal, that non-contentious proceeding to determine the boundary, in which one of the possible criteria is the last quiet enjoyment of possession, are being conducted. Justification of the lack of the plaintiff's economic interest for possessory protection is correct, which is why the appellate court in this part refers to the reasons for the decision as well. The established case law also represent grounds for the court's decision (Thus VSL in decisions I Cp 1496/98, II Cp 2075/99, I Cp 476/2000, I Cp 2900/2005, II Cp 796/2009, I Cp 3598/2010).

VSL, Decision I Cp 2695/2011, 22. 2. 2012: Disturbing conduct is a legal standard that has to be given meaning in each particular case. In that respect, it is necessary to consider all circumstances of the case and ensure that claims for possessory protection are not abused. Case law has repeatedly stressed that when deciding on justification of the request for judicial protection on the grounds of disturbance of possession, economic interest of the possessor has to be taken into account. The evaluation of the latter in such proceedings has the function of a test of whether with the action the plaintiff as a possessor really does not abuse the rights provided by law. Not every insignificant change of the existing state represents disturbance of possession. The conduct is disturbing only in the event of a legally relevant interference with possession. The absence of a direct economic interest may thus render the plaintiffs' legal interest for possessory protection questionable (Similarly: VSL Decision I Cp 3325/2005, VSL Decision I Cp 476/2000, VSK Decision I Cp 476/2006).

VSL, Decision II Cp 1397/2012, 28. 11. 2012: The parties did not dispute the fact that on 18. 5. 2011 the defendant verbally prevented the plaintiff from using his land, by chasing him away from the land. Since such defendant's conduct has altered the existing manner of the (joint) use of the land, the court correctly identified it as a disturbance (Article 33 and 35 of SPZ). In light of this explanation, the court justifiably upheld the claim for the 
prohibition of future disturbance. The appellate position that the change of possessory state was insignificant and has no practical implications for the plaintiff is incorrect. The appeal failed to realise that the subject of protection is possession of the defendant's land, not possession of the hedge. Since the plaintiffs have been using this land before the disturbance, but have refrained from doing so because of the defendant's prohibition, the interference was certainly not insignificant. In this regard, it is not important that the prohibition was only verbal (and not physical), because it was sufficient for the plaintiff to withdraw from his land. Therefore, bringing an action does not represent the abuse of the right, as stated in the appeal. The appeal is also incorrect in claiming that the plaintiffs are not entitled to possessory protection, because they are protected by provision on maintenance work on immovable property (Article 76 of SPZ). The kind of legal protection they choose to request is their decision. If conditions for possessory protection are met, they cannot be denied such judicial protection.

VSL, Decision I Cp 3421/2012, 2. 1. 2013: Correct is the conclusion of the court of first instance that the defendants' conduct (the removal of a prefabricated wall with a door and the removal of a sink) constitutes a disturbance. The appeal itself claims that with the removal of a prefabricated wall with a door, other persons gained access to the space in question, who had no access before this disturbance occurred. For that reason, the plaintiff's possession of the space in question - the hallway - is significantly restricted when compared to possession exercised before the disturbance occurred, which is legally considered a disturbing conduct. The removal of a sink is considered a dispossession, which is why there is no doubt that this represents disturbance of the plaintiff's possession.

It is not essential for the decision that the hallway is considered a common part of the building. It is important that it was in the plaintiff's exclusive possession, which was lost because of the defendant's actions.

Incorrect is the appellate opinion that the action should not be considered a disturbance due to the lack of a direct economic interest. The plaintiff has the interest to exclusively use the space in question, because this simplifies and qualitatively improves the use of office space, including the adjacent toilet. This certainly demonstrates economic interest of the plaintiff, who can thus leave her belongings in a disputed space without worrying, and does not need to lock the office space and the toilet, which facilitates her use thereof.

VSL, Decision II Cp 3123/2012, 17. 4. 2013: The court of first instance is correct that the court may also address the question of the plaintiff's economic interest for possessory protection in such proceedings, but only in the context of the assessment of whether in regard to the disturbing conduct, the plaintiff in the action refers to such insignificant change in the actual state that has no practical significance and represents only an insignificant hindrance for the exercise of the plaintiff's possession. The plaintiff's economic interest for possessory protection should therefore be assessed from the 
perspective of the prevention and sanctioning of arbitrary interference with the existing state of possession, or from the perspective of the prevention of the abuse of rights. ${ }^{20}$

The plaintiffs consider the defendant's decision to cut down a cypress and with it a part of the hedge, which, in their opinion, has been growing on the boundary between plots no. 2538 and 2537/2 and 2537/1, all c. c. x. v., a disturbing conduct. Given the findings of the court of first instance that $18 \%$ of the remaining stump of the cypress extended into the land of the plaintiffs and the established fact that the branches of the cypress reached into the hedge, which currently represents the boundary between the land of both parties, the plaintiff's economic interest for possessory protection in the present case is demonstrated in this regard. The defendant completely prevented possession over a thing with his disturbing conduct, since it is a widely known fact that once the tree is cut down, it will never grow back. This was therefore not merely a case of, for example, the trimming of the cypress, which would represent an insignificant interference with the exercise of possession of the hedge ${ }^{21}$, but rather its arbitrary removal, which, considering the findings of the court of first instance that the cypress partially represented the boundary between the parties, certainly reinforces the appellate court in its belief that such interference also holds practical importance for the plaintiffs.

In relations between two or more possessors of the same thing any action which arbitrarily alters or hinders the way in which the possession has been exercised until that point shall be considered to be a disturbance (Article 35 of SPZ). The boundary between the plots is no longer the same, which is also visible in the physical world, because there is now a hole in the hedge. Considering the purpose of possessory protection, the plaintiff has economic interest to prevent the defendant's arbitrary interference with the hedge, i.e. that the hedge remains unchanged (at least until the final decision on the boundary between the plots). Therefore, in addition to the claim for the restoration to the previous state (indent 1 of the operative part of the judgement), the claim for the prohibition of further similar disturbing actions (indent 2 of the operative part of the judgement) is justified as well. $^{22}$

VSL, Decision I Cp 389/2013, 28. 8. 2013: The defendant changed the route of the existing pathway and moved it more to the left (of the old pathway). With this action, he prevented the plaintiffs from using the old pathway and thus interfered with the existing state of possession (since the plaintiffs lost possession of the pathway, which they had been using up to that point). Therefore, the defendant's conduct (i.e. removal of the old

${ }^{20}$ Cf. decisions of the Higher Court in Ljubljana I Cp 1925/1999 of 1. 12. 1999 and I Cp 3598/2010 of 19. 1. 2011.

${ }^{21}$ According to case law, negligible interference includes, for example, pruning and trimming stems of a hedge, mowing grass and undergrowth - see Decision of the Higher Court in Ljubljana I Cp $2857 / 2011$ of 15.2 .2012$.

${ }^{22}$ In a decision on a claim for the protection against disturbance of possession, the court may also order a prohibition of further disturbance of possession and other measures necessary for the protection against further disturbance (Article 34 of SPZ). 
pathway and alteration of its route) is disturbance of possession of the old pathway. On the other hand, the court appointed expert I.ŠS. stated in his expert opinion that the new route of the pathway is fortified, and as such suitable for vehicles (such as a tractor, a tractor with a trailer or other attachments, off-road vehicles and even private cars), which means that the plaintiffs can use the new pathway to the same (or even larger) extent as they were able to use the old pathway before the disturbance. Therefore, they are not deprived in any way because of the change of the route of the pathway.

Case law $^{23}$ adopted a position that possessory protection is not justified or cannot be claimed, if a party has no adequate economic interest for such protection. The party has no such interest, if interference with his or her possession is insignificant or has no practical significance for him or her. As emphasised above, the plaintiffs in the present case can now use the new pathway (the defendant is not preventing them from doing so), which means that their position (in comparison with the previous use of the old route of the pathway) practically has not changed. Because they are therefore lacking adequate economic interest, they are not entitled to judicial protection of possession, and their claim for protection of possession had to be dismissed (as was correctly done by the court of first instance).

VSL, Decision II Cp 3222/2012, 28. 8. 2013: The appellate court further notes that the plaintiff's economic interest for the action for disturbance of possession is not legally relevant (the court of first instance determined that the plaintiff has no economic interest for the action and that his claim is thus also unjustified). Legal interest is relevant as a general procedural requirement; if there is no legal interest, the proceedings are not permissible, and an action should in such case be rejected (instead of consideration of the claim on the merits - assessment of (non)justification thereof).

VSL, Decision I Cp 1626/2013, 16. 10. 2013: It can be determined that the plaintiffs were disturbed both in driving with personal vehicles (they had to manoeuvre when entering and leaving the parking lot because of the placement of the cone), as well as in driving of emergency and delivery vehicles for the needs of their lands (they are not able to enter the parking lot). These findings confirm that the plaintiffs were disturbed in driving to and from the parking lot with any vehicle. Unacceptable is appellate reasoning that the placement of a cone is not an interference that would justify possessory protection. It is not an insignificant obstacle but an interference, because of which the manoeuvring vehicles are staying on the road longer when driving to and from the parking lot. There is a risk that vehicles might suffer damage as a result of hitting the cone with an iron rod. Driving with wider and larger vehicles is obstructed more than driving with smaller vehicles. Problems with driving and the accompanying risks (a risk of collision because of lingering on the road, a risk of damage as a result of hitting the cone) represent a

\footnotetext{
${ }^{23}$ See particularly decisions VSL II Cp 394/2013, VSM Cp 405/1997, VSL I Cp 495/2010 and VSL I Cp 476/2000. This position was already adopted during the validity of ZTLR, and also applies under SPZ.
} 
significant hindrance for the plaintiffs when they are driving to and from the defendants' parking lot. Considering the fact that the cone poses an obstacle for driving with any vehicle, the appellate statement that higher vehicles are unable to enter the parking lot because of the canopy is irrelevant.

VSL, Decision II Cp 2831/2013, 15. 1. 2014: The court of first instance found (item 7 of the decision issued by the court of first instance) that the defendant's action does not meet the legal standard of disturbance of possession. It correctly found that the intensity of disturbance of possession must be such that the possessor is partly deprived of possession or is disturbed in a quiet enjoyment of possession. In case of a single disturbing action, the action must be such that it decisively interferes with the possessor's quiet enjoyment of possession. In the opinion of the court of first instance, parking of a car on foreign immovable property because of a phone conversation and looking through a journal does not represent a situation in which legal protection under provisions of Articles 33 and 34 of SPZ would be justified. These conclusions of the court of first instance are correct and, in fact, nothing needs to be added. Therefore, the action, as it was determined in the present case, does not constitute a disturbing action. In view of such findings and the correct conclusion that the defendant parked the car at the far edge of the dirt road, so that he did not prevent the access of other vehicles to the building on the plaintiff's immovable property, which is clearly seen in photos submitted to the file, the court of first instance also correctly concluded that the duration of the alleged disturbing action is not decisive in this case.

VSL, Decision I Cp 3225/2013, 12. 2. 2014: The appellate court agrees with the findings that on 15. 9. 2012, the first defendant drove the tractor on the disputed pathway only once. ... Calling attention to the submitted photographs, which were supposed to prove that driving took place in both directions, cannot raise any doubts with the court of appeal in the correctness of this conclusion. It is not possible to draw such a conclusion solely on the basis of photographs, because it is not necessarily true that (all) the traces were formed as a result of the first defendant's driving to the vineyard and back. Since the plaintiff's immovable property is also burdened with servitude under the judgement $\mathrm{P}$ $41 / 1998$, it is possible that the visible trace was formed in the exercise thereof.

In regard to the second alleged disturbing action of 22. 9. 2012, the court determined (and this part of the findings is not contested in the appeal) that the second defendant D. H. walked on the pathway across the plaintiffs' immovable property, namely from the third defendant's vineyard to her house and then, together with visitors, back to the vineyard. It has not been proven for the third defendant to also walk along this pathway.

The plaintiffs never claimed that the alleged disturbing actions were repeated after 15.9. 2012 or 22. 9. 2012. Therefore, as concluded by the court of first instance, this was a onetime event that occurred during the time of grape-harvest, namely a one-time drive with a tractor on 15. 9. 2012, and the third defendant's walk from the vineyard and back on 22. 9. 2012, which was not repeated. Moreover, driving and walking was not carried out for 
the benefit of the same immovable property, but by two different persons and for the benefit of two different immovable properties. The appellate court agrees with the conclusion that neither the first nor the second action represents such interference with the existing state of possession that would justify possessory protection. These two actions did not prevent the plaintiffs from normally exercising actual control over their immovable property, nor did they restrict it - there have been no changes in possessory state as a result of these actions. Therefore, there is no legal basis for the court to grant protection to the plaintiffs.

VSL, Decision II Cp 3440/2013, 12. 3. 2014: The court of first instance found that the plaintiff has been parking in disputed parking spots no. 8 and 12 in parking lot $\mathrm{R}$ before April 2012. Therefore, she exercised possession of these two parking spots. Moreover, the appellant does not claim that further findings of the court of first instance, which determined that the plaintiff was no longer able to park in these two parking spots after obstacles were installed and that her existing (joint) possession was therefore undoubtedly disturbed, were incorrect. At this point, the appellate court rejects the defendant's substantive-law objection that the plaintiff has no economic interest for these proceeding, since she can carry out delivery elsewhere and can also park in the remaining parking spots, the same as before. The fact that the plaintiff was able to park in these two parking spots prior to the placement of obstacles, but was unable to do so since the disturbing action was carried out, represents the required legal - and with it, economic - interest for bringing an action for disturbance of possession. The question of whether she can carry out delivery by using another way is not even important, because the mere fact that she can no longer park justifies her economic interest for the proceedings.

The court of appeal further notes that the appellate allegation that the plaintiff's (joint) possession was not disturbed because the plaintiff was able to park her vehicle in the remaining parking spots, the same as before the disturbance, is incorrect. Any conduct/action that alters or hinders the way in which joint possession has been exercised until that point is considered disturbance among joint possessors (Article 35 of SPZ). Since the possibility to park on parking spots no. 8 and 12 was excluded after the disturbance, the way in which joint possession has been exercised until that point was undoubtedly altered or hindered, which is why this undoubtedly represents alteration or hindrance of the way in which the joint possession has been exercised until that point, which is why it constitutes disturbance of (joint) possession.

VSL, Decision I Cp 1783/2014, 13. 8. 2014: When the defendant raised doubts related to the necessity of judicial protection, the plaintiff explained in the section IV. of the application of 11. 5. 2013 that disturbing conduct is not insignificant, because it may result in the establishment of servitude. This is a convincing argument, since driving, carried out in such manner, is according to the statements of the parties only carried out a few times each year. Because driving takes place in an uninhabited area, not many impartial witnesses can be found who could testify in regard to the driving. These are the circumstances under which the question of when and where the defendant has been 
visiting his land may already become controversial within a few years. The risk that the plaintiff seeks to deter by bringing an action is that much greater, because the defendant admitted that in 2011 his previously established access to his land over plot No. 56/4, c. c. X., was prevented, that after 2011 he was accessing his land via plot No. 57/4 and plot No. 70, both c. c. X., that his access via plot no. 70, c. c. X was not possible in 2013 because of the crop planted on this land. It is obvious that in the last few years, the defendant has not resolved the issue of the access to his land plot No. 56/1, c. c. X, and that he will have to do so. Legal interest of the plaintiff, who wishes to keep his land unburdened, for the claim with which he claims the unlawfulness of respective driving and requests the prohibition of future driving - interest for legal protection - therefore cannot be denied.

Since the consequence provided by law for the lack of interest for legal protection is the dismissal of an action, and the court of first instance did not dismiss the action, it did not deny judicial protection. The court justified dismissal of the claim with a negligible change of possessory state, which is not a reason to be granted possessory protection, because Article 32 of SPZ, grants judicial protection against disturbance and dispossession. According to legal theory, disturbance of possession is an unlawful interference of lesser intensity in comparison with dispossession. The appeal correctly observes that there are no statutory provisions that would restrict possessory protection based on the intensity of interference.

The appellate court does not agree with the court of first instance that a disturbing conduct should result in some change, therefore in a permanent physical alteration of the plaintiff's meadow (e.g. permanently sunken tracks, lesser produce due to a trampled grass ...). The dismissal of the claim cannot be justified by referring to economic interest, since the law does not even require economic interest in order to bring an action for disturbance of possession or request judicial protection.

The lack of economic interest does not necessarily mean the lack of legal interest - interest for legal protection, since economic interest is a narrower concept in comparison to legal interest. The plaintiff cannot be denied legal interest for bringing an action for disturbance of possession, as stated above. Since possessory protection is granted by the law, legal reasons must also exist for this protection to be denied. Among other things, because possession is not an irrelevant fact. Only two aspects of the existence of possession or actual control over a thing, relevant in this situation, should be mentioned: - actual performance of driving over a longer period of time results in the acquisition of servitude by prescription (Article 217 of SPZ); - one way to determine boundaries in judicial proceedings is the last quiet enjoyment of possession (the fourth paragraph of Article 77 of SPZ).

VSL, Decision II Cp 2479/2015, 28. 10. 2015: Only if disturbing actions carried out by the defendants had resulted in an insignificant change of the existing state, which would have no practical significance and would represent only an insignificant hindrance to the 
plaintiff's exercise of possession, would the plaintiff have no benefit from possessory protection and would therefore also have no interest for such protection.

\subsection{Disturbance of possession of electricity}

VSL, Decision I Cp 4274/2010, 23. 3. 2011: The ruling on the right to be connected to electricity network is excluded in proceedings for disturbance of possession. Because the defendant disconnected electricity despite the existing Contract of sale and lease of electricity, the disconnection was unlawful, which means that the defendant disturbed the plaintiff's quiet possession. The defendant should first achieve the termination of Contract of sale and lease of electricity, concluded with the plaintiff, in order to be able to (legally) disconnect electricity.

VSL, Decision I Cp 1216/2011, 19. 10. 2011: The defendant was a customer of electric connector and the payer of electricity supplied. His conduct, when he failed to pay the supplied electricity with the intention to accomplish the disconnection of electricity supply to the plaintiff's studio, constitutes disturbance of the plaintiff's possession.

VSL Decision II Cp 1830/2012, 4. 7. 2012: The only reason why the plaintiff would not be entitled to possessory protection is if the defendant's conduct was based on a decision issued by an authoritative body or on the law, while the right to possession is, as mentioned above, irrelevant for possessory protection. The defendant acknowledged the plaintiff's possession of the apartment, which was exercised when electricity was disconnected. She only objected that possession was not quiet, because the plaintiff entered the apartment in a violent manner, which is not legally relevant, since this kind of possession is also protected (the second paragraph of Article 33 of SPZ).

During the course of proceedings, the previous state was established (electricity was connected) on the basis of an interim order (...). This is a temporary solution, valid for the duration of the proceedings, which is why the plaintiff has legal interest for the restoration to the previous state, and, consequently, under Article 34 of SPZ also for the prohibition of further disturbing actions of the same or similar kind.

\subsection{Possessory protection of the public good}

VSL, Decision I Cp 93/2010, 24. 3. 2010: Possessory protection of the public good is excluded.

VSL, Decision I Cp 3384/2013, 5. 3. 2014: The plaintiffs claimed that they were disturbed in their possession of streets and access roads. Such was also their claim. In a declaratory part of the claim, they requested the switch-off of electronic cards and removal of barriers. A declaratory part of the claim is unnecessary according to theory, and even inadmissible according to case law. In accordance with the correct observation of the court of first instance, the appellants as beneficiaries of the public good cannot be disturbed in 
possession thereof, as they cannot hold possession of the public good. Therefore, a described manner of traffic regime management in the public good cannot constitute a civil disturbing conduct.

VSL, Decision II Cp 902/2014, 9. 4. 2014: Immovable property acquires the status of public good facility with the issue of a declaratory decision, but the proof that immovable property truly has such status cannot be limited only to the delivery of the declaratory decision. The defendant submitted a certificate of the municipality which states that the road, in relation to which the plaintiff claims protection against disturbance of possession, constitutes the public good. He has proven with this authentic document that this is the public good, for which the protection against disturbance of possession is excluded according to case law.

\subsection{The exclusion of unlawfulness of disturbance}

VSL, Decision II Cp 4172/2009, 20. 1. 2010: In accordance with the provision of the third paragraph of Article 33 of SPZ, only the law can exclude the unlawfulness of disturbance.

VSL, Decision I Cp 513/2012, 22. 8. 2012: An action must be arbitrary and unlawful if it is to be considered disturbing. The possessor has no legal protection if the disturbance or dispossession was based on the law (the third paragraph of Article 33 of SPZ). Unlawfulness of interference with possession can also be excluded on the basis of a legal transaction. In the present case, the parties have agreed on the manner of the use of apartment and recorded the agreement in the form of a court settlement. Therefore, no unlawfulness exists in this case, and neither do the conditions for the plaintiff's success in a dispute over disturbance of possession.

VSL, Decision II Cp 759/2013, 9. 10. 2013: In the present proceedings for disturbance of possession, the plaintiff states that on 28 March 2012, the defendant cut off the supply of drinking water from the source of water supply called "the spring". The court of appeal fully agrees with the opinion of the court of first instance that the alleged disturbing action was not arbitrary or unlawful. The court of first instance properly assessed the proportionality of the measure adopted by the defendant to the pursued objective. It explained why the use of drinking water from the water source in questions is not permitted and referred to Article 22 of Rules on drinking water supply (hereinafter: Rules) and Article 8 of the Ordinance on drinking water supply in the Municipality of Brežice (hereinafter: Ordinance). The decision of the Constitutional Court UP-156/98, referred to by the plaintiff, considered a fundamentally different situation, which is not applicable in the present case. In the cited case, the water supply was interrupted because other persons who lived in the same building failed to pay for the supplied water. In the present case, the defendant acted in accordance with the law. Drinking water supply is under Article 149 of Environmental Protection Act a mandatory municipal service of general economic interest for environmental protection. Article 5 of Services of General Economic Interest Act stipulates that the use of public goods, which are provided by mandatory public 
services, is mandatory, if the law or an act issued on the basis thereof does not provide otherwise for a particular case. Previously cited Rules also oblige the owner of a building to ensure that the building is connected to a secondary water supply, if the building is located in a settlement area where supply of drinking water is provided by public services.

The defendant made it possible for the plaintiff to connect to a public water supply, which the plaintiff was obliged to do under the cited provisions. The plaintiff was also informed in due time that distribution of drinking water from the old water supply system will be suspended and that she has to arrange the connection to the public water supply network. The plaintiff's appellate statements that notifications from 2009 were irrelevant, because disturbing actions occurred in 2012, are therefore incorrect. It is precisely these two notifications which demonstrate that the plaintiff was informed in due time of the changes related to the drinking water supply. The efforts made by the defendant so that the plaintiff would not be left without drinking water are after all also demonstrated with the decisions of Intermunicipal Inspectorate, in which the defendant was ordered to connect to the public water supply. The fact that the decision is not yet final for S. $\breve{S}$. is completely irrelevant in the present case. The basis for the defendant's conduct can also be found in the previously cited Article 5 of Services of General Economic Interest Act, which the court of first instance otherwise did not refer to, together with provisions of previously cited Rules and Ordinance.

According to case law, unlawfulness is an objective element of disturbance of possession and is of crucial importance in disputes over disturbance of possession, because possession can be disturbed only by actions that oppose positive regulations and legal order or by actions and conduct for which a legal subject has no authorisation based on the existing legal basis. The court of first instance has adequately explained why the alleged disturbing action is not arbitrary and unlawful, while at the same time the plaintiff had the possibility to get connected to the public water supply, whereby the use of public goods provided by mandatory public services is even mandatory. For that reason, the decision of the court of first instance to dismiss the claim is correct. Unfounded is also the plaintiff's reference to the decision I Cp 1286/2004 of 6. 10. 2004, which is not comparable with the present case, because it considers an entirely different situation.

VSL, Decision I Cp 1821/2013, 4. 12. 2013: Unlawfulness of disturbance is excluded when this is explicitly stipulated by the law or when an action (conduct) is carried out on the basis of the implementing regulation, provided that this act was adopted on the basis of the law or that the authority to (more precisely) regulate legal relationships was delegated to this act by the law. An inspection decision is an authoritative unilateral individual act, with which a decision on the right/obligation of a party is made on the basis of the law/implementing regulation. The present inspection decision clearly imposes the obligation for the defendant to disconnect the plaintiff's electrical connector, which means that such disconnection, if carried out by the defendant, would not oppose legal order, and would thus, because of the exclusion of unlawfulness, not represent a disturbing action. 
VSL, Decision II Cp 3440/2013, 12. 3. 2014: Unlike the previously valid ZTRL, SPZ excludes unlawfulness of disturbance only if the disturbance is based on the law. A statutory determined phrase based on the law truly should not be interpreted so narrowly that the reason for the disturbance should be explicitly stated in the law; however, the provision constitutes an exception to the general rule which prohibits interference with the existing state of possession, and in law, the exceptions should always be interpreted restrictively. Case law has adopted a clear position that SPZ denies judicial protection only in cases when interference with possession is based on the law, ${ }^{24}$ and that according to the third paragraph of Article 33 of SPZ, only those persons who are permitted to interfere with possession under a special act are safe from the accusation that they caused disturbance. $^{25}$

Case law has also already interpreted a statutory text based on the law, namely, that disturbance of possession can be caused only by such actions and conduct that are contrary to positive regulation, legal order, or by actions and conduct for which legal subject has no authorisation granted on proper legal grounds, ${ }^{26}$ whereas legal theory already adopted a position that legal transaction, even when established in accordance with a valid legal order, can never exclude unlawfulness, while case law adopted a position that unlawfulness may be excluded if the conduct is based on a decree (or another executive act) issued on the basis of the law. In other words: unlawfulness of disturbance is excluded when this is explicitly stated by the law, or when an action/conduct is carried out on the basis of the implementing regulation, provided that the latter was adopted on the basis of the law or that the authority to (more precisely) regulate legal relationships was delegated to this act by the law.

VSL, Decision I Cp 1681/2014, 2. 7. 2014: In disputes over disturbance of possession, in addition to the question of whether the plaintiff was a possessor before the disturbance occurred, and the question of whether possession was really disturbed and whether the defendant is the one who disturbed possession, a question should also be addressed (in case of a proper objection) of whether the allegedly disturbing action really represents a disturbance and whether such action is arbitrary and unlawful. Unlawfulness is an objective element of disturbance of possession and is of crucial importance in disputes over disturbance of possession, because possession can be disturbed only by actions that oppose positive regulations and legal order. In its previous decision in this case, with which it reversed the initial decision of the court of first instance, the court of appeal explained at length that unlawfulness of disturbance is excluded when this is explicitly stipulated by the law or when an action/conduct is carried out on the basis of the implementing regulation, provided that this act was adopted on the basis of the law or

\footnotetext{
${ }^{24}$ Decision of the Higher Court in Ljubljana of 4. 7. 2007, No. I Cp 2158/2007, Decision of the Higher Court in Ljubljana of 12. 8. 2009, No. I Cp 1764/2009.

${ }^{25}$ Decision of the Higher Court in Ljubljana of 7. 4. 2010, No. II Cp 402/2010.

${ }^{26}$ Decision of the Higher Court in Koper of 21. 11. 2006, No. I Cp 258/2006.
} 
that the authority to (more precisely) regulate legal relationships was delegated to this act by the law.

An inspection decision is an authoritative unilateral individual act, with which a decision on the right/obligation of a party is made on the basis of the law/implementing regulation. The present inspection decision clearly imposes the obligation for the defendant (because of an actual state which opposes legal regulation - provisions of Energy Act) to disconnect the plaintiff's electrical connector, which means that such disconnection, if carried out by the defendant, would not oppose legal order, and would therefore, because of the exclusion of unlawfulness, not represent a disturbing action. The only fact that is legally relevant for a decision in this case is whether the inspection decision is final.

\subsection{Active and passive legitimation}

VSL, Decision II Cp 4172/2009, 20. 1. 2010: In disputes over disturbance of possession, it is not only a person who carries out a disturbing action that is passively legitimised, but also a person who orders or approves the action or for whose benefit the action is carried out.

VSL, Decision I Cp 1330/2011, 14. 9. 2011: Since in disputes over disturbance of possession (according to both legal theory and established and uniform case law) both a person who causes disturbance (directly performs a disturbing action), as well as a person who ordered such action or for whose benefit it was carried out (deriving from the principle of inadmissibility to retain benefits obtained by an unlawful disturbing conduct) are passively legitimised, whereby the defendant did not refute the fact that as a joint possessor (co-owner) he had benefited from the deprivation of the plaintiff's joint possession, it is legally irrelevant whether he ordered the action or if he was aware of his brother's order to replace the lock, or whether he agreed with such action, as well as whether the action was carried out by his own will as well.

VSL, Decision II Cp 1137/2011, 19. 10. 2011: ... the court of first instance correctly responded that in a dispute over disturbance of possession, judicial protection is granted with respect to the last state of possession and any disturbance that has occurred (the first paragraph of Article 33 of SPZ) and that the examination of the action for disturbance of possession is strictly confined to the assessment and proving of facts relating to the last state of possession and any disturbance that has occurred (Article 426 of ZPP). It correctly explained that the otherwise undisputed fact that the state of ownership of the disputed plot has changed on 3. 5. 2010 (therefore, after the day of disturbance) is of no consequence for the assessment of the present disturbance. Because of the change in the state of ownership, the resulting procedural situation is governed by the first paragraph of Article 190 of ZPP, which states that the disposal of the thing, which is subject to litigation, shall not prevent the proceedings from being completed between the same parties. The appellate allegation that the plaintiff is not actively legitimised is therefore unfounded. The defendant justified the change in possessory state with statements referring to the change of ownership of the disputed immovable property, which he also 
insisted upon in the appeal. The court of appeal holds that the transfer of ownership of the disputed immovable property does not result in an automatic change in possessory state, contrary to what the appellant mistakenly believes.

VSL, Decision II Cp 3100/2011, 15. 2. 2012: In disputes over disturbance of possession, it is not only a person who carries out (or orders) a disturbing action that is passively legitimised, but also a person who later approves the action or for whose benefit the action is carried out. Otherwise, it would be very difficult, if not impossible, for the plaintiffs to claim judicial protection of possession, since a third party could always appear who would recognise a disturbing action as their own and thus exclude passive legitimation of a particular defendant. In each case, the role of persons who did not necessarily directly actively participate in a disturbing action, but have benefited from it, and who have not distanced themselves from the arbitrary conduct either, should therefore be assessed.

VSL, Decision I Cp 3047/2011, 11. 4. 2012: In disputes over disturbance of possession, it is not only a person who carries out a disturbing action that is passively legitimised, but also a person who approves the action or for whose benefit the action is carried out.

VSL, Decision I Cp 751/2012, 26. 9. 2012: Current case law referred to the question of who is a person causing disturbance of possession (Article 33 of SPZ). Rules that regulate disturbance of possession also apply in case of dispossession, since the fundamental issue is the same with both types of disputes, namely the question of who is considered to have caused the disturbance. Undoubtedly, a person who performs an action that disturbs possession is considered to have caused disturbance. In addition to such persons, disturbance can also be caused by a person who approves the action or a person who benefits from the action (thus, for example, Decision of VSL, No. I Cp 3047/2011, with further references to case law and opinions in literature, and VSK I Cp 1586/2005). An agreement between a person who has disturbed possession directly and a person who has disturbed possession indirectly, and the fact that the actions of the latter are consistent with the will of the person who was directly causing disturbance, are already sufficient in case of the existing family relationship (see the decisions mentioned above).

VSL, Decision II Cp 1175/2013, 23. 10. 2013: Decision of the court of first instance that the defendant is passively legitimised in this dispute is correct from the perspective of substantive law. It is not decisive whether he removed the vine and spruce hedge personally or if it was done by someone else (perhaps his son, who was present when disturbing actions have been carried out). The first court determined that the defendant had hired and paid a contractor, that he was organising and overseeing the work, that his role was not minor, that he has not distanced himself from disturbing actions, that he did all that as a manager of J. L.'s assets. 


\subsection{The claim}

VSM, Decision I Cp 2477/2009, 2. 2. 2010: In regard to the claim itself, the appeal correctly states that under the provision of Article 34 of SPZ, the claim is not entirely properly formed, but it cannot be dismissed solely for that reason. Thus, in possessory proceedings, where it is essential for the protection of disturbed possession to order the prohibition of further disturbance of possession or the restoration of possession and possible other necessary measures, the declaratory part of the claim is unnecessary, and the conclusion that possession has been disturbed belongs in the reasoning for the decision. However, since the claim in question contains a description of disturbing action, i.e. the barrier installed by the defendant, and is referred to by the claim for the removal of this barrier (condemnatory claim), which was upheld by the court in point 2 of the decision, a dismissal of declaratory claim would result in unsuitable condemnatory claim, which is otherwise specified and also enforceable.

VSL, Decision I Cp 22/2010, 8. 4. 2010: In civil proceedings for disturbance of possession, the plaintiff has no legal interest for a declaratory part of the claim. It is true that the established case law is different, because it allows the plaintiffs to also invoke declaratory parts of the claim, but never as separate claims, only in connection with condemnatory claims or claims for restitution or prohibition.

In regard to the statement that the second obstruction was raised by one of the defendants, the findings of the court of first instance that statements of the action do not justify restitutory or prohibitory parts of the claim against the defendants are correct. Furthermore, the action is not inconsistent, since in III. point of the action the plaintiff in his subsequent statements also claims that "they constructed three vertical concrete garden slabs and two parts of the road kerb", whereby it is not clear whom the plaintiff refers to when he talks about the installation of the second obstruction. Despite the inconsistency of the action, the conclusion of the court of first instance, that the plaintiff would not be able to eliminate the inconsistency of the action in this part even by adding to specific statements within the same claim, cannot be upheld.

VSL, Decision II Cp 2705/2010, 20. 10. 2010: Article 34 of SPZ provides that in a decision on a claim for protection from disturbance of possession the court shall order a prohibition against further disturbance of possession or order the return of possession and other measures necessary for protection against further disturbance. The plaintiff filed a claim in which he requested declaration of (the manner of) disturbance of possession, in addition to the restoration to the previous state. Regardless of this fact, the procedural nature of the claim is still condemnatory. Before deciding on the claim, the court otherwise has to determine whether dispossession or disturbance of possession occurred, but these factual findings belong in the reasoning and not in the operative part of the judgement. 
Concerning the determined joint possession of the plaintiff and disturbance caused when the defendants changed the lock cylinder on the front door of a residential holiday cottage, the decision of the court is correct in the part where the court upheld the claim for the restoration to the previous state, whereby the defendants are required to hand over the keys to the newly installed lock on the door of a residential holiday cottage to the plaintiff or to remove the new lock and reinstall the old one.

VSL, Decision I Cp 3907/2010, 6. 2. 2011: Dismissal of the restitutory part of the claim was justified, because all installed obstructions have already been removed and the plaintiffs were no longer hindered in their walking and driving; therefore, the need for judicial protection to this effect no longer existed.

VSL, Decision II Cp 95/2011, 13. 4. 2011: In the present case, the plaintiff brought an action for disturbance of possession. Proceedings in disputes over disturbance of possession are regulated in the third part of Civil Procedure Act, which governs special procedures, while an action for the protection of ownership against interference is an action that is examined in regular proceedings. Since a different type of procedure is provided for each invoked claim the court should not have allowed the amendment of the action.

VSL, Decision I Cp 44/2011, 5. 5. 2011: In disputes over disturbance, case law permits such claims and operative parts of decisions as the claim raised by the plaintiff, so that the disturbance which has occurred is established first, followed by the prohibition of actions that are described in a declaratory part of the action. Recent case law adopted a theoretically more correct position and is rejecting declaratory parts of actions, because a declaratory action may be filed only under conditions laid down in Article 181 of ZPP (especially because this requires the finding of facts - the disturbance that has occurred). This was done by the court of first instance as well. In doing so, the court failed to recognise that the second point of the operative part of the decision, in which the court upheld the claim and prohibited the defendant from interfering with the plaintiff's possession with these and similar actions in the future, remained unspecified. Taking this approach, in the second point of the operative part the court should have precisely determined the actions, which the defendant is prohibited from performing, using a description from the declaratory part of the action. The appeal rightly states that it is not actually clear what the court prohibited the defendant from doing. That could also be understood as meaning that the defendant is prohibited from carrying out all actions, which was not requested by the applicant. With that, the operative part of the decision became unspecified and incomprehensible, which constitutes an absolute severe violation of civil procedure provisions under point 14 of the second paragraph of Article 339 of ZPP.

VSL, Decision II Cp 4912/2010, 25. 5. 2011: In case of actions for disturbance of possession, it is also important that declaratory claims are always connected to a condemnatory part and that the declaratory part therefore explains the condemnatory part. 
The claim should thus be considered uniformly, whilst the dismissal of declaratory part would generally result in the vagueness of condemnatory part as well. Therefore, case law still allows declaratory part of the claim in proceedings over disturbance of possession, and there is no rational reason for the court of appeal to dismiss the action in its declaratory part.

The appellant obviously incorrectly understands the concept of self-help, which in a dispute over disturbance of possession refers only to the state of possession, and not perhaps to some other legally protected interest.

VSL, Decision I Cp 603/2011, 3. 8. 2011: Recent case law has been rejecting declaratory parts of actions for disturbance, since they may be filed only under conditions laid down in Article 181 of ZPP. The court's conclusion that the condemnatory and prohibitory part of the claim would remain unspecified upon the rejection of the declaratory part of the action is not correct. In fact, it includes a fully specified obligation of the defendant (a description of the defendant's conduct, with a precise geometrical definition of a part of the pathway where the restoration to the previous state is being sought), and the claim therefore requires no further legal reasoning. Even if this was the case, the court would be required to specifically re-form the condemnatory and prohibitory part of the claim using the declaratory part.

VSL, Decision I Cp 1216/2011, 19. 10. 2011: An action for disturbance of possession is a condemnatory action. Condemnatory elements are found in the restitutory part, in the restoration to the previous state, which was dismissed by the contested decision, because the restitution occurred during the course of proceedings, and in the prohibition of further disturbing actions, i.e. in the imposition of obligation to refrain from actions that would again result in disturbance of possession. Unfounded is the appellate allegation that the operative part of the contested decision is incomprehensible and contradictory, since the court of first instance found no disturbance. The plaintiff brought only a condemnatory claim in the proceedings (for restitution and prohibition). A declaratory claim was not raised. The court of first instance clearly explained in the reasoning on page nine of the contested decision that the defendant disturbed the plaintiff's possession of the studio, when he knowingly refrained from fulfilling his duties (non-payment of electricity). The fact the defendant's conduct was disturbing was recognised by the court of first instance as a legally relevant fact, which is required for bringing the prohibitory claim.

VSL, Decision I Cp 3366/2011, 25. 4. 2012: In proceedings for disturbance of possession, the possessor may request the restoration to the alleged previous state. However, since the plaintiff claimed only that she exercised possession of immovable property by mowing the grass, the defendant has a duty to establish such state of possession which will allow the exercise of possession in the asserted manner.

VSL, Decision I Cp 1215/2013, 12. 6. 2013: A declaratory part of the claim in claims based on disturbance of possession is unnecessary and not allowed. 
VSL, Decision II Cp 1175/2013, 23. 10. 2013: Theory and case law agree that the claim in dispute over disturbance of possession is of condemnatory nature. This follows from Article 34 of SPZ. However, case law also permits the claim formed as the one brought by the plaintiff in the present case: in addition to the restoration to the previous state and the prohibition of further disturbance, the declaration of the manner in which possession was disturbed may also be claimed (see, for example, decisions VSL I Cp 22/2010, VSM I Cp 2477/2009, VSL II Cp 2080/2005). The procedural nature of such claim is also condemnatory. By first establishing the manner in which possession was disturbed, the court only precisely determines a condemnatory claim in possessory proceedings. It is more appropriate to form a claim as a condemnatory claim, but the claim cannot be rejected or dismissed simply because it was not shaped in the best possible manner.

VSL, Decision II Cp 618/2014, 2. 4. 2014: Theory and case law agree that the claim in dispute for disturbance of possession is of condemnatory nature. This follows from Article 34 of SPZ. Nevertheless, it is also true that case law sometimes permits the claim in possessory disputes to be formed so that specific disturbing actions are determined described first, followed by a claim for restitution and a claim for prohibition. That is permitted when the determination of the manner in which possession was disturbed precisely determines the condemnatory claim. However, the plaintiff sufficiently determined both the claim for restoration to the previous state and the claim for the prohibition of future interference with her possession, and a preliminary description of previous disturbing actions of the defendant is thus not necessary for the determination of the claim for disturbance of possession.

VSL, Decision I Cp 1886/2015, 15. 7. 2015: In regard to a declaratory part of the claim in a dispute over disturbance of possession, case law has repeatedly adopted a position that this part is generally not necessary (and has to be rejected on procedural grounds because of the lack of legal interest - and not dismissed on substantive grounds as stated by the appeal), but is nevertheless still permitted. The court has to decide within the scope of the claim. In the present case, it is especially apparent that declaratory and prohibitory parts of the operative part of the decision are intertwined to such extent that only their coexistence provides a sufficient degree of preciseness and consequentially the enforceability of the decision. The court of second instance has therefore upheld the claim. 


\section{Scope of Judicial Protection}

\section{$1 \quad$ In general}

In a decision on a claim for protection from disturbance of possession the court shall order a prohibition against further disturbance of possession or order the return of possession and other measures necessary for protection against further disturbance (Article 34 of SPZ).

Depending on the intensity of unlawful interference with possession, we distinguish between (1) dispossession and (2) disturbance of possession.

In dispossession, the person who is causing disturbance either deprives the possessor of a thing in the case of movable property (e.g. the buyer arbitrarily deprives the seller of movable property, which the seller failed to deliver within the agreed time limit), or "occupies" the thing and thus prevents the possessor from exercising possession of the entire immovable property or part thereof in the case of immovable property (e.g. A replaces the lock of the apartment and thus prevents $\mathrm{B}$ from exercising possession of the apartment, or A "occupies a disputed border area" and thus prevents the neighbour from exercising possession of a part of immovable property.

In disturbance of possession, the interference with possession is of lesser intensity than in case of dispossession. The person causing disturbance does not interfere with possession to the extent that would entirely exclude the possessor from exercising possession, but is instead disturbing him or her with his actions. Disturbance can be caused in various manners. If, for example, A starts to arbitrarily use a part of foreign immovable property as a pathway, he thereby carries out a disturbing action. Disturbance of possession may according to our theory and case law also be caused verbally (Frantar, 1993: 322; Stojanović, Pop-Ggeorgiev, 1980: 174). Such an example would be a possessor who abandons the exercise of possession because of a serious threat made by the person who is causing disturbance (e.g. a person threatens his roommate that he will be beaten or killed unless he moves out of the apartment). Unlawful immissions constitute disturbance of possession as well. A possessor may thus also invoke possessory protection due to excessive noise.

In practice, a claim for the protection of possession generally consists of three parts (if we ignore the part referring to costs) (Gavella in Gavella, Josipović, Gliha, Belaj, Stipković, 1998: 182). First, a declaratory claim (problems arising from a declaratory claim are discussed below) requires the determination of disturbance and the manner in which a disturbing action has been carried out (e.g. "The defendant A.A., residing ...., 
disturbed the plaintiff B. B., residing ..., in his direct possession of immovable property, the plot with ID designation 657-100/0-0 - a meadow measuring $400 \mathrm{~m}^{2}$, c. c. Meadow, by stacking the entire immovable property with construction material on 17 August 2016 and by constructing a shack in the south-western part of the plot"). This is followed by the restoration to the previous state (claim for restitution), which seeks to restore the previous state of possession (e.g. "The defendant is obliged to restore the previous state of possession within 8 days in order to avoid enforcement, and shall to that effect remove construction material from the entire plot and the shack in the south-western part of immovable property with ID designation 657-100/0-0 - a meadow measuring $400 \mathrm{~m}^{2}$, c. c. Lower Meadow, and plant the grass in the same place where the construction material and the shack had been located"). Finally, this is followed by a prohibition of further disturbance of possession (e.g. "The defendant shall in the future be prohibited from disturbing possession of immovable property, the plot with ID designation 657-100/0-0 a meadow measuring $400 \mathrm{~m}^{2}$, c. c. Lower Meadow, with the same or similar actions in order to avoid enforcement"). Unlike ZTLR, SPZ no longer contains the provision on a financial penalty as a threat against the violation of court order on further disturbance.

In proceedings for disturbance of possession, the plaintiff has no legal interest for a declaratory part of the claim. It is true that the established case law is different, because it allows the plaintiffs to also invoke declaratory parts of the claim, ${ }^{1}$ but never as separate claims, only in connection with condemnatory claims or claims for restitution or prohibition. $^{2}$ Plaintiffs thus generally raise declaratory claims (in addition to condemnatory) in disputes over disturbance. Regardless of this fact, the procedural nature of the claim is still condemnatory. Before deciding on the claim, the court has to determine whether dispossession or disturbance of possession occurred, but these factual findings belong in reasoning and not in the operative part of the judgement. In one of the decisions, the court correctly stated: "In disputes over disturbance, case law permits such claims and operative parts of decisions as the claim raised by the plaintiff, so that the disturbance which has occurred is established first, followed by the prohibition of actions that are described in a declaratory part of the action. Recent case law adopted a theoretically more correct position and has been rejecting declaratory parts of actions, because a declaratory action may be filed only under conditions laid down in Article 181 of ZPP (especially because this requires the finding of facts - the disturbance that has occurred).This was done by the court of first instance as well. In doing so, the court failed to recognise that the second point of the operative part of the decision, in which the court upheld the claim and prohibited the defendant from interfering with the plaintiff's

\footnotetext{
${ }^{1}$ In the case of actions for the disturbance of possession, it is also important that declaratory claims are always connected to the condemnatory part and that the declaratory part therefore explains the condemnatory part. The claim should thus be considered uniformly, whilst the dismissal of the declaratory part would generally result in the vagueness of condemnatory part. Therefore, case law still permits the declaratory part of the claim in proceedings over disturbance of possession, and there is no rational reason for the court of appeal to dismiss the action in its declaratory part (VSL, Decision II Cp 4912/2010, 25. 5. 2011).

${ }^{2}$ VSL, Decision I Cp 22/2010, 8. 4. 2010.
} 
possession with these and similar actions in the future, remained unspecified. Taking this approach, in the second point of the operative part the court should have precisely determined the actions, which the defendant is prohibited from performing, using a description from the declaratory part of the action. The appeal rightly states that it is not actually clear what the court prohibited the defendant from doing. That could also be understood as meaning that the defendant is prohibited from carrying out all actions, which was not requested by the applicant. With that, the operative part of the decision became unspecified and incomprehensible, which constitutes an absolute severe violation of civil procedure provisions under point 14 of the second paragraph of Article 339 of ZPP." 3

"Recent case law has been rejecting declaratory parts of actions for disturbance, as they may be brought only under conditions laid down in Article 181 of ZPP. The court's conclusion that condemnatory and prohibitory parts of the claim would remain unspecified upon the rejection of the declaratory part of the action is not correct. In fact, the latter includes a fully specified obligation of the defendant (a description of the defendant's conduct, with a precise geometrical definition of the part of pathway where the restoration to the previous state is being sought), so that the claim requires no further legal reasoning. Even if this was the case, the court would be required to specifically reform condemnatory and prohibitory parts of the claim on the basis of the declaratory part." 4

The claim may also propose other measures for the protection against further disturbance. For example, the owner of a tennis court may be ordered to install appropriate safety nets or other suitable protection that will prevent tennis balls from landing on the plaintiff's immovable property in the future.

The provision of Article 229 of ZIZ, which regulates a repeated disturbance of possession, also pursues the goal of conducting proceedings in economical and speedy manner. If a debtor voluntarily fulfilled his obligation, which was based on the enforcement title that was issued in proceedings for disturbance of possession, or if enforcement was carried out against him, and he disturbed possession again in a manner that is essentially no different from the previous disturbance, a court issues a new enforcement order on the basis of the same enforcement title following the creditor's proposal. In such case, a proposal for enforcement must be submitted within 30 days from the day when the creditor learned of the repeated disturbance of possession, and no later than one year after the repeated disturbance has occurred. These time limits are identical to the time limits under Article 32 of SPZ. Only the moment when the creditor learned of the disturbance is relevant for the subjective time limit, since the person causing disturbance remained the same.

\footnotetext{
${ }^{3}$ VSL, Decision I Cp 44/2011, 5. 5. 2011

${ }^{4}$ VSL, Decision I Cp 603/2011, 3. 8. 2011.
} 
2

Case law

\subsection{In general}

VSK, Decision I Cp 725/2014, 13. 1. 2015: The appeal also unjustifiably claims that the court exceeded the limits of Article 34 of SPZ in the granting of possessory protection to the plaintiff. The reinstatement of possession in the present case does not only mean the relinquishment of the land to be further cultivated by the plaintiff, but the defendant must ensure that the plaintiff can exercise the same possession as before the disturbance. The land has to be returned in a state that will allow the plaintiff to carry out mowing again. This can only happen if the crop is removed from the ploughed part of the land, the land is straightened out and the grass is replanted.

\subsection{Operative part of the decision on disturbance of possession}

VSL, Decision I Cp 343/2011, 23. 3. 2011: The operative part of a decision on disturbance of possession with which the court upholds the claim traditionally consists of three parts. The first is a determination of possession and disturbing conduct, the second is an order for the defendant to restore the previous state of possession, and the third contains a prohibition of the same or different disturbing conduct in the future. Such claim fully complies with Article 34 of SPZ, which provides the scope of judicial protection.

VSL, Decision I Cp 1330/2011, 14. 9. 2011: The scope of judicial protection in disputes over disturbance of possession is stipulated in Article 34 of SPZ, which provides that in a decision on a claim for protection from disturbance of possession the court shall order a prohibition against further disturbance of possession or order the return of possession and other measures necessary for protection against further disturbance. Therefore, facts established by the court in regard to disturbance of possession under point 1 of the operative part of the decision (findings on when and how disturbance of possession occurred, with which disturbing action) do not belong in the operative part of the decision but in the reasoning (especially since this is a case of wrongful finding of facts, not of a right or legal relationship).

VSL, Decision I Ip 3521/2011, 26. 10. 2011: The operative part of a decision on disturbance of possession, which requires the debtor to refrain from the same and similar disturbing actions in the future, is an enforcement title, which is enforceable, since, considering the obligation of omission, the (subsequent) time limit for the fulfilment of obligations is conceptually not an option.

\subsection{The claim}

VSM, Decision I Cp $2477 / 2009$, 2. 2. 2010: In regard to the claim itself, the appeal correctly states that under the provision of Article 34 of SPZ, the claim is not entirely properly formed, but it cannot be dismissed solely for that reason. Thus, in possessory 
proceedings, where it is essential for the protection of disturbed possession to order the prohibition of further disturbance of possession or the restoration of possession and possible other necessary measures, a declaratory part of the claim is unnecessary, and the conclusion that possession has been disturbed belongs in the reasoning for the decision. However, since the claim in question contains a description of disturbing action, i.e. the barrier installed by the defendant, and is referred to by the claim for the removal of this barrier (condemnatory claim), which was upheld by the court in point 2 of the decision, a dismissal of the declaratory claim would result in an unsuitable condemnatory claim, which is otherwise specified and also enforceable.

VSL, Decision I Cp 22/2010, 8. 4. 2010: In civil proceedings for disturbance of possession, the plaintiff has no legal interest for a declaratory part of the claim. It is true that the established case law is different, because it allows the plaintiffs to also invoke declaratory parts of the claim, but never as separate claims, only in connection with condemnatory claims or claims for restitution or prohibition.

In regard to the statement that the second obstruction was raised by one of the defendants, the findings of the court of first instance that statements of the action do not justify restitutory or prohibitory parts of the claim against the defendants are correct. Furthermore, the action is not inconsistent, since in III. point of the action the plaintiff in his subsequent statements also claims that "they constructed three vertical concrete garden slabs and two parts of the road kerb", whereby it is not clear whom the plaintiff refers to when he talks about the installation of the second obstruction. Despite the inconsistency of the action, the conclusion of the court of first instance, that the plaintiff would not be able to eliminate the inconsistency of the action in this part even by adding to specific statements within the same claim, cannot be upheld.

VSL, Decision II Cp 2705/2010, 20. 10. 2010: Article 34 of SPZ provides that in a decision on a claim for protection from disturbance of possession the court shall order a prohibition against further disturbance of possession or order the return of possession and other measures necessary for protection against further disturbance. The plaintiff filed a claim in which he requested declaration of (the manner of) disturbance of possession, in addition to the restoration to the previous state. Regardless of this fact, the procedural nature of the claim is still condemnatory. Before deciding on the claim, the court otherwise has to determine whether dispossession or disturbance of possession occurred, but these factual findings belong in the reasoning and not in the operative part of the judgement.

Concerning the determined joint possession of the plaintiff and disturbance caused when the defendants changed the lock cylinder on the front door of a residential holiday cottage, the decision of the court is correct in the part where the court upheld the claim for the restoration to the previous state, whereby the defendants are required to hand over the keys to the newly installed lock on the door of a residential holiday cottage to the plaintiff or to remove the new lock and reinstall the old one. 
VSL, Decision I Cp 3907/2010, 6. 2. 2011: Dismissal of the restitutory part of the claim was justified, because all installed obstructions have already been removed and the plaintiffs were no longer hindered in their walking and driving; therefore, the need for judicial protection to this effect no longer existed.

VSL, Decision II Cp 95/2011, 13. 4. 2011: In the present case, the plaintiff brought an action for disturbance of possession. Proceedings in disputes over disturbance of possession are regulated in the third part of Civil Procedure Act, which governs special procedures, while an action for the protection of ownership against interference is an action that is examined in regular proceedings. Since a different type of procedure is provided for each invoked claim the court should not have allowed the amendment of the action.

VSL, Decision I Cp 44/2011, 5. 5. 2011: In disputes over disturbance, case law permits such claims and operative parts of decisions as the claim raised by the plaintiff, so that the disturbance which has occurred is established first, followed by the prohibition of actions that are described in a declaratory part of the action. Recent case law adopted a theoretically more correct position and is rejecting declaratory parts of actions, because a declaratory action may be filed only under conditions laid down in Article 181 of ZPP (especially because this requires the finding of facts - the disturbance that has occurred). This was done by the court of first instance as well. In doing so, the court failed to recognise that the second point of the operative part of the decision, in which the court upheld the claim and prohibited the defendant from interfering with the plaintiff's possession with these and similar actions in the future, remained unspecified. Taking this approach, in the second point of the operative part the court should have precisely determined the actions, which the defendant is prohibited from performing, using a description from the declaratory part of the action. The appeal rightly states that it is not actually clear what the court prohibited the defendant from doing. That could also be understood as meaning that the defendant is prohibited from carrying out all actions, which was not requested by the applicant. With that, the operative part of the decision became unspecified and incomprehensible, which constitutes an absolute severe violation of civil procedure provisions under point 14 of the second paragraph of Article 339 of ZPP.

VSL, Decision II Cp 4912/2010, 25. 5. 2011: In case of actions for disturbance of possession, it is also important that declaratory claims are always connected to a condemnatory part and that the declaratory part therefore explains the condemnatory part. The claim should thus be considered uniformly, whilst the dismissal of declaratory part would generally result in the vagueness of condemnatory part as well. Therefore, case law still allows declaratory part of the claim in proceedings over disturbance of possession, and there is no rational reason for the court of appeal to dismiss the action in its declaratory part. 
The appellant obviously incorrectly understands the concept of self-help, which in a dispute over disturbance of possession refers only to the state of possession, and not perhaps to some other legally protected interest.

VSL, Decision I Cp 603/2011, 3. 8. 2011: Recent case law is rejecting declaratory parts of actions for disturbance, since they may be filed only under conditions laid down in Article 181 of ZPP. The court's conclusion that the condemnatory and prohibitory part of the claim would remain unspecified upon the rejection of the declaratory part of the action is not correct. In fact, it includes a fully specified obligation of the defendant (a description of the defendant's conduct, with a precise geometrical definition of a part of the pathway where the restoration to the previous state is being sought), and the claim therefore requires no further legal reasoning. Even if this was the case, the court would be required to specifically re-form the condemnatory and prohibitory part of the claim using the declaratory part.

VSL, Decision I Cp 1216/2011, 19. 10. 2011: An action for disturbance of possession is a condemnatory action. Condemnatory elements are found in the restitutory part, in the restoration to the previous state, which was dismissed by the contested decision, because the restitution occurred during the course of proceedings, and in the prohibition of further disturbing actions, i.e. in the imposition of obligation to refrain from actions that would again result in disturbance of possession. Unfounded is the appellate allegation that the operative part of the contested decision is incomprehensible and contradictory, since the court of first instance found no disturbance. The plaintiff brought only a condemnatory claim in the proceedings (for restitution and prohibition). A declaratory claim was not raised. The court of first instance clearly explained in the reasoning on page nine of the contested decision that the defendant disturbed the plaintiff's possession of the studio, when he knowingly refrained from fulfilling his duties (non-payment of electricity). The fact the defendant's conduct was disturbing was recognised by the court of first instance as a legally relevant fact, which is required for bringing the prohibitory claim.

VSL, Decision I Cp 3366/2011, 25. 4. 2012: In proceedings for disturbance of possession, the possessor may request the restoration to the alleged previous state. However, since the plaintiff claimed only that she exercised possession of immovable property by mowing the grass, the defendant has a duty to establish such state of possession which will allow the exercise of possession in the asserted manner.

VSL, Decision I Cp 1215/2013, 12. 6. 2013: A declaratory part of the claim in claims based on disturbance of possession is unnecessary and not allowed.

VSL, Decision II Cp 1175/2013, 23. 10. 2013: Theory and case law agree that the claim in dispute over disturbance of possession is of condemnatory nature. This follows from Article 34 of SPZ. However, case law also permits the claim formed as the one brought by the plaintiff in the present case: in addition to the restoration to the previous state and the prohibition of further disturbance, the declaration of the manner in which possession 
was disturbed may also be claimed (see, for example, decisions VSL I Cp 22/2010, VSM I Cp 2477/2009, VSL II Cp 2080/2005). The procedural nature of such claim is also condemnatory. By first establishing the manner in which possession was disturbed, the court only precisely determines a condemnatory claim in possessory proceedings. It is more appropriate to form a claim as a condemnatory claim, but the claim cannot be rejected or dismissed simply because it was not shaped in the best possible manner.

VSL, Decision II Cp 618/2014, 2. 4. 2014: Theory and case law agree that the claim in dispute for disturbance of possession is of condemnatory nature. This follows from Article 34 of SPZ. Nevertheless, it is also true that case law sometimes permits the claim in possessory disputes to be formed so that specific disturbing actions are determined described first, followed by a claim for restitution and a claim for prohibition. That is permitted when the determination of the manner in which possession was disturbed precisely determines the condemnatory claim. However, the plaintiff sufficiently determined both the claim for restoration to the previous state and the claim for the prohibition of future interference with her possession, and a preliminary description of previous disturbing actions of the defendant is thus not necessary for the determination of the claim for disturbance of possession.

\section{$2.4 \quad$ Interim measures}

VSL, Decision I Cp 1879/2011, 1. 6. 2011: Since the applicant can access the vineyard by using another pathway and cultivate it, the circumstances that would justify the issue of interim order are not demonstrated. Especially considering the statements of the action, a different decision would mean that the court is not ruling on the securing of the claim, but is already regulating legal relationships, which will be determined with a decision on the merits of the defendant's alleged disturbing conduct. Case law uniformly states that regulatory interim measures, the content of which is identical to the claim, should be assessed restrictively, and that they should be granted only if an irreparable or possibly irreparable damage was justifiably demonstrated.

VSL, Decision I Cp 1853/2011, 8. 6. 2011: Based on life experience, it is possible that a person may suffer possibly irreparable damage if they are unable to access their home and personal items, or a company may suffer such damage if it is unable to access their documents or a stamp and if it is prevented from carrying out its activity, but this is not necessary or self-evident - the plaintiffs should have explained why this applies to their case. Meanwhile, the plaintiffs did not even prove as probable, because they stated nothing in this regard, that it will be possible to eliminate consequences suffered by the defendant because of the granted interim order, or to restore the previous state if the claim is proved to be unfounded in the course of proceedings.

VSL, Decision I Cp 2451/2013, 25. 09. 2013: The likelihood of the existence of a claim in disputes over disturbance of possession is demonstrated if a plaintiff or applicant for interim order proves as likely that he is entitled to possessory protection with a certain 
content. With the proposed interim order, the plaintiff did not request his own power connection, but merely such conduct or omission by the defendants that would ensure the supply of electricity to his apartment on the top floor of the house in the same manner as before the electricity supplier disconnected electricity. All conduct or omissions by the defendants should therefore be considered together as a whole, not individually.

The likelihood of the existence of a claim in disputes over disturbance of possession is demonstrated if a plaintiff or applicant for interim measures proves as likely that he is entitled to possessory protection with a certain content. Under the provisions of the first paragraph of Article 24 of SPZ, possession is direct actual control over a thing. A person interferes with actual control over a thing if he or she imposes a different manner of the use of the thing from the existing one. The right to protection of possession (Article 34 of SPZ) authorises a possessor to compel a person, who has restricted his actual possession of a thing or the existing use thereof, to refrain from such conduct or to establish a state that existed prior to the interference.

The court of first instance has otherwise correctly restricted the scope of judicial protection that can be claimed by the plaintiff in the present case (Articles 33 and 34 of SPZ), when it found that the question of who would be obliged to pay the bills for the consumed electric energy, the plaintiff or the defendants, and why the plaintiff has ceased to pay the bills, is not subject to assessment. It is also true that this is the case of a regulatory interim order, which can be issued only for serious reasons. However, as the appeal correctly observes, the plaintiff explained in the action in an accurate and comprehensive manner why he requires possessory protection, what was the disturbing conduct and why the plaintiff's stay in the apartment was significantly impeded as a result of this action. As the plaintiff states in the appeal, it is true that he did not request his own electricity connection with the proposed interim order, but merely such conduct or omission by the defendants that would ensure the supply of electricity to his apartment on the top floor of the house in the same manner as before the electricity supplier disconnected the electricity. All conduct or omissions by the defendants should therefore be considered together as a whole, not individually. Their subsequent conduct, whereby the second defendant ordered the connection to public electricity network with the electricity supplier by installing a new electricity panel, which provides electricity only in the lower floor of the house, is not unconnected with the state after the electricity supplier disconnected the electricity as a result of the non-payment of bills. The plaintiff as a non-owner was therefore deprived of the possibility to reconnect to the electricity network, even after paying the bills, in addition to the access to public electricity network. Therefore, the conclusion of the decision that the defendant's actions before and after the disconnection jointly do not represent a disturbing action against the plaintiff, and that the likelihood of his claim in the dispute over disturbance of possession is therefore not demonstrated, is unrealistic. 
Legal Regulation of Possession in the RePublic of Slovenia

R. Vrenčur 


\section{Protection in the Case of Two or More Possessors}

\section{In general}

In a relationship between two or more possessors of the same thing, any action which arbitrarily alters or hinders the way in which the possession has been exercised until that point shall be considered to be a disturbance (Article 35 of SPZ).

In addition to possessory protection against third persons, a possessor also enjoys possessory protection within the mutual relationship in the case of joint possession (Article 25 of SPZ). The relationship between the indirect and direct possession is neither joint possession nor partial possession.

For the purpose of commenting on Article 35 of SPZ, it is necessary to distinguish between joint possession and partial possession. If several possessors exercise possession of the same thing, we are talking about joint possession. Considering the phrasing of Article 35 of SPZ, which states "in the relationship between several possessors of the same thing ...", it should be concluded that only in the case of joint possession is actual control jointly exercised by several persons over the same thing. In the case of partial possession, each possessor exclusively exercises possession of a specific part of the thing. Several possessors can exercise joint possession of a part of the thing as well. In such case, all of them are externally considered partial possessors, but joint possessors in terms of their internal relationship. For example, if the spouses exercised joint possession of their common apartment, disturbance of joint possession would occur if one spouse arbitrarily replaced the lock, thereby preventing the other spouse from entering the apartment. The person who caused the disturbance would thus arbitrarily change the previous manner of the exercise of possession. However, if a lessor, who leased the advertising space on his house to the lessee for the purpose of commercial advertising, removed a poster, this would constitute interference with partial possession, i.e. interference with exclusive possession of a part of the thing, and not interference with joint possession. From the perspective of possessory states, a difference lies in the fact that actual control may be exercised exclusively by a partial possessor in the case of partial possession and jointly by all joint possessors in the case of joint possession. However, for the purposes of possessory protection, we have to conclude that the latter it is granted to both joint possessors and partial possessors.

(Joint) possession of heirs seems slightly more complicated. An heir acquires possession of the decedent's things at the moment of the decedent's death (Article 29 of SPZ). If there are several heirs, joint possession is generally established. However, if the decedent left in his will the servitude of habitation - habitatio (Article 247 of SPZ) on a part of the 
house to one of the heirs, partial possession is established for the holder of servitude of habitation at the moment of the decedent's death on the part of the thing that is the subject of this servitude right. On the remaining part of immovable property, joint possession of heirs is established. The holder of the right of habitation is therefore an exclusive possessor of a part of the thing (partial possession). A situation may also occur where the decedent rented or leased immovable property to a third party while he or she was still alive. OZ provides that in case of the lessor's or lessee's death, the lease is not terminated, unless otherwise agreed. This means that the lease may continue with the lessor's heirs (Article 618 of OZ). A usufruct, habitation or use do not cease with the death of the owner of the thing on which these personal servitudes are established, either (Article 241 in connection with Articles 246 and 248 of SPZ). This means that constructive possession relationship continues to exist, and only the lessor or lessee are replaced. In such case, the heirs may not acquire a different type of possession from the one previously exercised by the decedent. While the heirs become joint possessors at the moment of the decedent's death, their joint possession is indirect. Since indirect possession is based on the existence of legal relationship which establishes a state of direct and indirect possession, the interference with indirect possession of another joint possessor constitutes interference with legal relationship, which is the subject of a petitory dispute. However, if one of indirect joint possessors disturbs possession of a direct possessor, this is considered interference with direct possession of, for example, a tenant, and not interference with indirect joint possession.

Since the quality of possession generally does not change as a result of universal succession, it is necessary to respect constructive possession relationships that were established prior to that. This means that the heirs, who otherwise became (indirect) joint possessors of the thing, may not request the thing to be delivered in their direct possession solely on the basis of Article 29 of SPZ. However, they may make this request when, for example, a usufruct is extinguished by expiration (the first paragraph of Article 241 of SPZ).If the person who exercised actual control was a holder of precarium, the heirs will not be so limited, since they may terminate precarium relationship at any time and request on these grounds the delivery of the thing in their direct possession.

\section{$2 \quad$ Case law}

VS, Decision II Ips 669/2007, 1. 10. 2009: The Supreme Court further agrees with the position adopted by the state prosecutor that in a relationship between joint possessors, any conduct is considered disturbing that arbitrarily alters or interferes with the existing manner of the exercise of joint possession (Cf. Article 35 of SPZ) and that the owner of servient immovable property is in the exercise of control over his thing restricted by the beneficiary's proper exercise of the servitude.

VSL, Decision II Cp 1426/2010, 7. 7. 2010: SPZ does not define objects of possessory protection, not does it exclude particular things from possessory protection. The act even defines the protection of possession exercised by several possessors in more details, with 
a more precise definition of a disturbing conduct (Article 35 of SPZ). Therefore, the unsubstantiated appellate allegation that the protection of possession is not provided for common areas cannot be upheld.

VSL, Decision I Cp 2305/2010, 17. 11. 2010: Joint possession means that each joint possessor may exercise actual control over the entire thing, whereby each time one joint possessor exercises possession, this action represents some restriction for the simultaneous exercise of possession by another joint possessor. In mutual relationship in the case of joint possession, a possessor enjoys possessory protection against another joint possessor in accordance with Article 35 of SPZ, which provides that in relationship between several possessors of the same thing, any conduct which arbitrarily alters or hinders the existing manner of the exercise of possession is considered to be a disturbance. In order for joint possession to be considered to be disturbed (under substantive law), the alteration of the existing state has to be such that it prevents the plaintiff from exercising actual control over the thing or significantly alters the existing manner of the exercise of possession of the thing.

VSL, Decision II Cp 4657/2010, 23. 3. 2011: If several persons hold the keys to the garage, joint possession is considered to be disturbed if one of them arbitrarily and by force changes the lock, because such action represents the alteration of the existing manner of the joint use of the garage.

VSL, Decision II Cp 1514/2012, 19. 12. 2012: A grammatical interpretation of Article 35 of SPZ leads to a conclusion that not all alterations of the existing state constitute disturbance of possession. The court of appeal determined that the court of first instance reached a substantively wrong conclusion that the installation of air conditioner on the facade has altered the existing manner of the exercise of joint possession of the facade and that the installation of the air conditioner is therefore considered a disturbing action. Since two air conditioners were already installed on the facade, the court of appeal assessed that the installation of the air conditioner in question had not altered the existing exercise of the plaintiff's joint possession of the facade.

The plaintiff's joint possession of the facade of a multi-unit apartment building derives from the fact that a facade is an integral part of the multi-unit apartment building, in which the apartment used by the plaintiff is also located. Actual control over external walls is usually realised and observed in rare sporadic actions, which are necessary for the maintenance of these parts and of the entire building. The fact that two air conditioners were already installed on the facade before the alleged disturbing conduct occurred shows that the installation of air conditioners on the facade was an established manner in which joint possessors of the facade exercised actual control over the facade. By installing a new air conditioner, the defendants therefore did not substantively alter the existing manner of the exercise of (the plaintiff's) joint possession of the facade. The fact that no air conditioner was previously installed in that spot does not allow the opposite conclusion, because the plaintiff did not exercise partial possession of the thing, i.e. exclusive actual 
control over a part of the thing. It is typical for joint possession, the protection of which is sought by the plaintiff, that each joint possessor exercises actual control over the entire thing. Moreover, the court did not find that the installed air conditioner interfered with the functionality of the facade or significantly impeded its maintenance. The plaintiff made no substantiated statements to this effect either. Given the above explanation, the plaintiff's exercise of joint possession of the facade (in terms of the exercise of joint possession, as explained above) has not been altered or hindered with the installation of air conditioner; therefore, the installation of air conditioner does not constitute a legally relevant interference within the meaning of Article 35 of SPZ. 


\section{Protection on the Basis of a Right}

\section{$1 \quad$ In general}

A dispute over disturbance of possession (Article 32) notwithstanding, judicial protection of possession may be claimed on the basis of the right to possession (Article 36 of SPZ).

Despite the ongoing proceedings for disturbance of possession, petitory proceedings, in which the right to possession is being examined, may be conducted at the same time. The proceedings are different in terms of their legal nature. In possessory proceedings, judicial protection is granted with respect to the last state of possession and any disturbance that has occurred. The right of possession and good faith of the possessor are not taken into account (the first paragraph of Article 33 of SPZ). In petitory proceedings, on the other hand, the right to possession is being examined, for example on the basis of an action for ownership. Since the examination of a right is excluded in possessory proceedings, the objection that would be based on a right is also not permitted. Therefore, it is necessary to initiate new proceedings, which can be conducted concurrently with possessory proceedings.

For example, since these are two different procedures, proceedings for disturbance of possession and proceedings for determination of boundaries may run parallel as well. Likewise, according to Austrian theory, there is no factual or legal relationship between proceedings for disturbance of possession and a dispute over boundaries, so they are not in competition with one another (Illedits, Illedits-Lohr, 1999: 212). Even though the judge in non-contentious proceedings may also rule on the basis of the last quiet enjoyment of possession, which is a decisive criterion in proceedings for disturbance of possession as well, these procedures do not overlap and are thus not mutually exclusive. The first one is focused on the determination of boundaries (petitory), while the second is focused only on the protection of the last (not necessarily quiet) state of possession (possessory). In accordance with the rule "petitorium absorbet possessorium", ${ }^{1}$ which represents an important point of contact between the two procedures, the claim for the disturbance of possession would have to be dismissed in the event of the parallel course of both

\footnotetext{
${ }^{1}$ This rule derives from the priority of procedures concluded with the force of res judicata. If, in case of a parallel course of petitory and possessory proceedings, the final decision in petitory proceedings is issued first, the right takes precedence over the last state of possession. On the other hand, if possessory proceedings are concluded finally before petitory proceedings, priority is given to the last state of possession. The rule is justified particularly with the principle of the prohibition of abuse of rights (Article 12 of SPZ, Article 7 of OZ) and the principle of good faith and fairness (Article $5 \mathrm{OZ}$ ).
} 
proceedings, if non-contentious proceedings concluded with the force of res judicata before possessory proceedings and boundaries were determined to the detriment of the plaintiff in possessory proceedings.

For example, if a buyer arbitrarily deprives the seller of a thing, which was the subject of the purchase, because the seller failed to deliver the thing to the buyer in spite of his commitment to do so, the buyer thereby unlawfully interfered with the seller's possession. It is true that the seller should have delivered the thing to the buyer within the agreed time limit, but this is a matter of petitory proceedings, which are based on the assumed obligations. In terms of the regulation of possession, however, this is an arbitrary interference with the seller's possession by the buyer. Here, too, the rule "petitorium absorbet possessorium" applies, which means that the court will have to dismiss the claim for the protection of possession, if petitory proceedings that are based on the sales contract (and on the obligation of the seller to carry out a realisation act, the subject of which is the delivery of the thing to the buyer) are concluded with the force of res judicata before the possessory dispute.

In both cases, the court must consider the objection of "the right" in possessory proceedings when deciding on the protection of possession, which is the only exception in possessory disputes.

\section{Case law}

VSL, Decision II Cp 4422/2009, 20. 1. 2010: In proceedings for disturbance of possession, the court grants protection with respect to the last state of possession and any disturbance that has occurred.In this regard, the right to possession and good faith of the possessor are not taken into account (the first paragraph of Article 33 of SPZ) and in these proceedings it is therefore irrelevant whether the defendant might exercise possession on the basis of the right to possession. The only exception to this rule is an objection that is associated with the rule "petitorium absorbet possessorium", which was used by the court of first instance as well. With regard to the appellate statement that the court applied this institute without proper legal grounds, the court of appeal notes that while this institution really is not explicitly enacted, Article 36 of SPZ provides that a dispute over disturbance of possession notwithstanding, judicial protection of possession may be claimed on the basis of the right, which also represents legal grounds for the application of this institute, because the failure to comply with this rule would otherwise result in an impossible situation in cases when petitory proceedings are concluded before possessory proceedings. In a dispute over possession, the defendant may therefore exceptionally invoke his right to possession on the basis of this rule, wherein this objection may only be considered if a person who allegedly disturbed possession acquired the right to possession on the basis of a judicial decision, which has to be final and enforceable. The prevailing position in both theory and case law supports the opinion that such objection may be invoked in possessory proceedings (Cf. Decision of VSC Cp 710/2004, Decision 
of VSL I Cp 767/2004, Decision of VSL II Cp 543/2009, Decision of VSK I Cp 669/2005).

VSL, Decision I Cp 621/2011, 22. 6. 2011: When the border was determined, the right to possession of the disputed area along the border between lands was determines as well; this decision became final during the course of the present proceedings. It is worth emphasising that the purpose of possessory protection is a temporary and provisional regulation, which lasts until someone proves in civil procedure that they have the right to possession (the rule petitorium absorbet possessorium). During the course of litigation, the plaintiff therefore also acquired the absolute protection of the disputed part of immovable property and not only provisional possessory protection.

VSK, Decision Cp 16/2013, 29. 1. 2013: The appellant did not dispute the fact that petitory and possessory proceedings ran parallel for a certain period, and that during the time when possessory proceedings were being conducted, a litigation has concluded in which the plaintiff was ordered to clear out the apartment on the ground floor of the apartment building M. 2/a, empty it of all her belongings and return the apartment to D. S.'s (joint) possession. The plaintiff's claim in possessory proceedings is based exactly on possession of this apartment, which the plaintiff has allegedly disturbed by preventing the flow of hot water into the apartment. Since the claim is therefore based on possession of the apartment, the application of the rule petitorum absorbet possesorium was appropriate. A situation thus occurred where the court had to exceptionally consider the objection of a right in possessory proceedings. Since the appellant has no legal title that would justify her occupation of the apartment, but is instead obliged to relinquish it to the plaintiff, she may not seek possessory protection against the latter.

VSK, Decision Cp 71/2013, 5. 3. 2013: The interpretation of the content of Article 36 of SPZ in the appeal is incorrect. The article states that a dispute over disturbance of possession notwithstanding, judicial protection of possession may be claimed on the basis of the right to possession. Both procedures may therefore run parallel, and if petitory proceedings are concluded earlier, the court must in accordance with the rule petitorium absorbet possessorium consider the objection of a right when deciding on the protection of possession. In the present case, this rule does not apply. The defendant herself admitted that the way of necessity was established finally for the benefit of her plot and the burden of the plaintiff's plot even before the present dispute over possession. Nevertheless, this does not mean that the defendant may arbitrarily exercise this right when she is hindered in the exercise of a way of necessity, but should resort to legal means instead. If she is actually impeded in the exercise of her right, she will succeed in proceedings against the opposing party both in terms of contents as well as necessary costs.

VSL, Decision II Cp 3177/2012, 24. 4. 2013: A decision in a dispute over possession, even though it becomes final and enforceable, is just a temporary measure and only applies until a decision is issued on the disputed right in ordinary proceedings (petitory proceedings). This means that a possessor is protected until the opposing party can prove 
that he or she is the one who has the right to possession. If, in case of a parallel course of petitory and possessory proceedings, the final decision in petitory proceedings is issued first, the right takes precedence over the last state of possession (the rule petitorium absorbet possessorium). In the present case, in addition to possessory proceedings in question, the plaintiffs simultaneously initiated petitory proceedings in which the claim for the determination of a servitude right was dismissed, which means that they have no (servitude) right to possession; therefore, they would no longer enjoy possessory protection, if such decision had already become final. However, because of the plaintiffs' appeal, the petitory decision has not yet become final, which is why they cannot be denied protection against disturbance of possession at this moment, and the court must consider their claim, which is based on possession, as if petitory proceedings do not exist. If the judgement issued in petitory proceedings becomes final before the court rules (again) in these possessory proceedings, a situation would occur that is governed by the rule petitorium absorbet possessorium, and in such case their claim would have to be dismissed without any further consideration.A final decision in petitory proceedings is that point in proceedings until which possessory protection is sensible, but after which the (temporary) purpose thereof is exhausted. ${ }^{2}$

VSL, Decision I Cp 2291/2015, 21. 10. 2015: The court grants judicial protection in disputes over disturbance of possession with respect to the last state of possession and any disturbance that has occurred. In this regard, the right to possession and good faith of the possessor are not taken into account. Possessory protection therefore does not derive from the right to possession, but from a bare possession as actual control over a thing. Any person who exercises actual control over a thing at the time before the disturbance occurred has active legitimation in possessory proceedings. In a dispute over possession, the defendant may exceptionally invoke his or her right to possession, but only if a person who allegedly disturbed possession acquired the right of possession on the basis of a final judicial decision.

\footnotetext{
${ }^{2}$ See Decision of the Higher Court in Ljubljana of 1. 9. 2004, No. I Cp 1291/2004.
} 
Legal Regulation of Possession in the Republic of Slovenia: R. Vrečur

\section{References}

Baur, F., Baur, J. F. \& Stürner, R. (1999) Sachenrecht (München: Verlag C.H. Beck).

Finžgar, A. (1952) Civilno pravo - Stvarno pravo (Ljubljana: Univerza v Ljubljani Pravna fakulteta).

Finžgar, A. (1980) Temeljna lastninskopravna razmerja, Zakon z uvodnimi pojasnili in komentarjem (Ljubljana: ČZ Uradni list SRS).

Finžgar, A. (1985) O varstvu posredne posesti (Ljubljana: Pravnik, No. 8-10/1985).

Flume, W. (1992) Allgemeiner Teil des Bürgerlichen Rechts (Berlin - Heidelberg: Springer Verlag).

Frantar, T. (1993) Stvarno pravo - stvarne pravice, posest, nujne poti, meje, kmetijska zemljišča (Ljubljana: GV).

Gavella, N., Josipović, T., Gliha, I., Belaj, V. \& Stipković, Z. (2007) Stvarno pravo - 1. Zvezek (Zagreb: Narodne Novine).

Gschnitzer, F. (1985) Österreichisches Sachenrecht (Wien-New York: Springer Verlag).

Honsell, H., Vogt, N. P. \& Geiser, T. (1998) Kommentar zum Schweizerischen Privatrecht - Schweizerisches Zivilgesetzbuch II (Basel und Frankfurt am Main: Helbing \& Lichtenhahn).

Illedits, A. \& Illedits-Lohr, K. (1999) Nachbarrecht (Wien: Orac Verlag).

Juhart, M. (2002) Stvarnopravni zakonik - Uvodna pojasnila (Ljubljana: GV).

Juhart, M., Tratnik, M., Vrenčur, R., Berden, A., Keresteš, T., Rijavec, V. \& Vlahek, A. (eds.) (2004) Stvarnopravni zakonik s komentarjem (Ljubljana: GV Založba).

Juhart, M., Tratnik, M. \& Vrenčur, R. (2007) Stvarno pravo (Ljubljana: GV Založba).

Koziol, H., Bydlinski, P. \& Bollenberger, R. (eds.) (2005) ABGB - Allgemeines Bürgerliches Gesetzbuch Kommentar (Wien - New York: Springer Verlag).

Koziol, H. \& Welser, R. (1991) Grundriß des bürgerlichen Rechts - Sachenrecht, Familienrecht, Erbrecht, Band II (Wien: Manz Verlag).

Krisper-Kramberger, M. (1985) Varstvo posredne posesti, In: Pravnik, 3-4, pp. 145.

Petzold, R. (1981) Münchener Kommentar zum Bürgerlichen Gesetzbuch - Band 4 (München: Beck Verlag).

Rummel, P. et al. (2000) Kommentar zum Allgemeinen bürgerlichen Gesetzbuch (Wien: Manz Verlag).

Sajovic, B. (2000) Posest (Ljubljana:Uradni list RS).

Sajovic, B. (1994) Osnove civilnega prava - Stvarno pravo I (Ljubljana: ČZ Uradni list $\mathrm{RS})$.

Schwab, K. H. \& Prütting, H. (1997) Sachenrecht (München: Verlag C.H. Beck).

Schwimann, M. et al. (1998) ABGB Praxiskommentar, Band 2 (Wien: Orac Verlag).

Stanković, O. \& Orlić. M. (1989) Stvarno pravo (Beograd: Savremena administracija).

Štempihar, J. (1962) Osnove civilnega prava II - Stvarno pravo (Ljubljana: Univerza v Ljubljani - Pravna fakulteta). 
Stojanović, D. \& Pop-Georgiev, D. (1980) Komentar zakona o osnovnim svojinskopravnim odnosima (Beograd: Službeni list SFRJ).

Tratnik, M. (2002) Stvarnopravni zakonik z uvodnimi pojasnili (Ljubljana: Uradni list RS).

Tratnik, M. \& Vrenčur, R. (2008) Zemljiškoknjižno pravo v teoriji in praksi (Maribor: Inštitut za nepremičninsko pravo Maribor).

Ude, L. (1988) Civilni pravdni postopek (Ljubljana: ČZ Uradni list RS).

Vrenčur, R. (2011) Med subjektivno in objektivno koncepcijo posesti, Zbornik Pravne fakultete Univerze v Mariboru - 200 let Občnega državljanskega zakonika (Maribor: Pravna fakulteta Univerze v Mariboru).

Westermann, H. P., Gursky, K. H. \& Eickmann, D. (1998) Westermann Sachenrecht (Heidelberg: C. F. Müller Verlag).

Wolf, E. (1999) Sachenrecht (München: Verlag C.H. Beck). 